UNIVERSIDADE DE SÃO PAULO

FACULDADE DE ECONOMIA, ADMINISTRAÇÃO E CONTABILIDADE DEPARTAMENTO DE ADMINISTRAÇÃO PROGRAMA DE PÓS-GRADUAÇÃO EM ADMINISTRAÇÃO

A IMAGEM DO PAÍS DE ORIGEM COMO FONTE DE VANTAGEM COMPETITIVA NO MERCADO INTERNACIONAL: UM ESTUDO EXPLORATÓRIO NO SEGMENTO DA MODA BRASILEIRA

Mariana Bassi Sutter

Orientador: Prof. Dr. Edison Fernandes Polo 
Prof. Dr. João Grandino Rodas

Reitor da Universidade de São Paulo

Prof . Dr. Reinaldo Guerreiro

Diretor da Faculdade de Economia, Administração e Contabilidade

Prof. Dr. Adalberto Américo Fischmann

Chefe do Departamento de Administração

Prof. Dr. Lindolfo Galvão de Albuquerque

Coordenador do Programa de Pós-Graduação em Administração 


\title{
A IMAGEM DO PAÍS DE ORIGEM COMO FONTE DE VANTAGEM COMPETITIVA NO MERCADO INTRENACIONAL: UM ESTUDO EXPLORATÓRIO NO SEGMENTO DA MODA BRASILEIRA
}

\author{
Dissertação apresentada ao Departamento de \\ Administração da Faculdade de Economia, \\ Administração e Ciências Contábeis da \\ Universidade de São Paulo, como um dos \\ requisitos para obtenção do titulo de Mestre \\ em Ciências.
}

Orientador: Prof. Dr. Edison Fernandes Polo

\section{Versão Corrigida}

(Versão Original encontra-se na Faculdade de Economia, Administração e Contabilidade da USP)

\section{SÃO PAULO}


FICHA CATALOGRÁFICA

Elaborada pela Seção de Processamento Técnico do SBD/FEA/USP

\section{Sutter, Mariana Bassi}

A imagem do país de origem como fonte de vantagem competitiva no mercado internacional: um estudo exploratório no segmento da moda brasileira / Mariana Bassi Sutter. -- São Paulo, 2012.

$164 \mathrm{p}$.

Dissertação (Mestrado) - Universidade de São Paulo, 2013.

Orientador: Edison Fernandes Polo.

1. Administração estratégica 2. Vantagem competitiva 3. Moda 4. Cultura brasileira 5. Imagem - Brasil I. Universidade de São Paulo. Faculdade de Economia, Administração e Contabilidade. II. Título.

CDD -658.4012 
Dedico esta dissertação aos meus familiares. Em especial aos meus Pais, Celso e Jurema, ao meu Tio Marcelo e à minha Prima Luíza, pelo apoio, amor, motivação e paciência. 


\section{AGRADECIMENTOS}

Ao longo da breve, mas intensa trajetória no curso de mestrado em Administração da FEA tive a sorte de contar com o apoio incondicional da minha família e também com a ajuda de amigos, de profissionais, de professores e de colegas que se tornaram grandes parceiros de pesquisa e amigos, pessoas que de alguma forma colaboraram para o desenvolvimento deste estudo e para a minha formação como pesquisadora.

Em primeiro lugar, agradeço aos meus familiares, em especial meus Pais, que tanto me motivaram e muito contribuíram ao entenderem minha ausência, sem a qual a realização desta dissertação não seria possível.

Agradeço ao Prof. Dr. Edison Fernandes Polo por ter assumido o desafio de me orientar, por ter acreditado no meu potencial e no tema de pesquisa sobre o qual eu escolhi dissertar.

Agradeço aos Professores membros da banca de qualificação, Prof. Dr. Geraldo Luciano Toledo e Profa. Bernadete Lourdes Marinho, por suas importantes contribuições para estrutura desta dissertação, pelos ensinamentos em aula, pelos artigos produzidos em coautoria, pela amizade, motivação, inspiração e exemplo a ser seguido na carreira acadêmica.

A todos os demais Professores do programa de pós-graduação da FEA com os quais eu tive a oportunidade de cursar disciplinas, desenvolver pesquisas e dividir experiências, em especial, o Prof. Dr. Silvio Aparecido dos Santos, pela ajuda e fundamental apoio na fase de qualificação, a Profa. Dra. Ana Cristina Limongi-França pelo aprendizado, estímulo e amizade e Prof. Dr. Nuno Fouto pela ajuda com contatos para a coleta de dados na fase empírica do estudo.

Agradeço ao Prof. Dr. Juracy Parente da Fundação Getúlio Vargas pelos ensinamentos em marketing e pesquisa, a Profa. Dra. Kathia Castilho, ao Prof. Dr. André Robic e Profa. Dra. Luciane Robic do IBmoda, pela demonstração de interesse e incentivo para estudo do tema escolhido.

Aos amigos, com maior experiência acadêmica, Patrícia, Victor, Flávia, Durval, Eduardo, Pilli, Barbara e Greici pelo carinho, apoio, paciência e ensinamentos. Agradeço aos demais amigos de mestrado e parceiros de pesquisa, em especial, Simone, Cecília, Silvye, Camila, Lívia, Raquel, Bassiro e Marília, pelos conhecimentos adquiridos 
juntos, pelos momentos compartilhados, pela ajuda e, principalmente, pelo grande apoio durante o desenvolvimento da dissertação.

Ao meu Tio Marcelo, à minha prima Luiza e à grande amiga Talita pelo apoio, carinho, acolhimento e tolerância ao longo de todo o desenvolvimento da pesquisa. Agradeço também aos amigos da minha família Virginia, Daniel, Regina e Carlos, pelo exemplo e pelo incentivo à carreira acadêmica. À Profa. e amiga Rosa, pela ajuda com a tradução dos roteiros da pesquisa empírica para a língua Inglesa e interpretação das gravações das entrevistas com os compradores internacionais.

Agradeço a toda equipe do PPGA, da secretaria de Pós-graduação e da Biblioteca da FEA-USP pela colaboração e atenção, em especial a Fabiana, Daniela, Eloisa, Francisco, Cida, Lucimar, Ivanete e Bianca.

À equipe de Profissionais da Abit, em especial ao Evilásio e a Ana Paula, pela colaboração com a pesquisa e auxílio com respondentes. A Heloisa e Rémi pelo interesse no estudo, por terem promovido os contatos e viabilizado entrevistas.

Agradeço a todos os agentes de mercado entrevistados que aceitaram participar da pesquisa, pelo tempo e atenção dedicados.

A todos que, direta ou indiretamente, contribuíram para a conclusão desta importante etapa, meus sinceros agradecimentos. 
"Daí começou, no Brasil, em data nada remota, uma valorização, pelos brasileiros, de suas frutas e de seus vegetais, de seus alimentos, de seus doces e de seus queijos, em face dos alimentos, doces, queijos, frutas importadas da Europa. Uma valorização, também, de suas tradições de modos tradicionais de residirem e de mobilizarem suas residências". 


\section{RESUMO}

O estudo relaciona dois temas relevantes e atuais: a imagem do país de origem e fontes de vantagens competitivas. Ao longo dos últimos anos identificou-se uma tendência do Brasil ganhar visibilidade no âmbito internacional, por isso, o mercado internacional demonstra interesse pela oferta brasileira. Assim, a conjuntura atual mostra-se oportuna para empresas desenvolverem suas ofertas para inserção em mercados externos. Algumas pesquisas indicam que o Brasil transmite a imagem de um país habitado por pessoas alegres e acolhedoras, com clima tropical e com paisagens paradisíacas. Nesse sentido, o presente estudo tem como proposta compreender quais atributos da imagem do país de origem representam fonte de vantagem competitiva no mercado internacional. Optou-se por realizar o estudo no segmento da moda brasileira. De modo a responder ao problema proposto, levantou-se o referencial teórico relacionado às fontes de vantagens competitivas, à imagem do país de origem, ao segmento da moda, à brasilidade e aos atributos de brasilidade na moda. Realizou-se uma pesquisa empírica de natureza exploratória e abordagem qualitativa. Para coleta de dados, elaboraram-se dois roteiros de entrevista semiestruturados que foram utilizados para entrevistar, em profundidade, cinco agentes de apoio à inserção da moda brasileira no mercado internacional (roteiro um) e quatro agentes de mercado demandantes (roteiro dois). Os dados foram coletados por meio de entrevista centralizada no problema e analisados utilizando-se a técnica de análise de discurso. Os resultados obtidos sugerem que a imagem do Brasil é entendida pelo mercado internacional como um país com pessoas afetivas e hospitaleiras, com mulheres sensuais, que apresenta uma cultura miscigenada (índios, africanos, portugueses e imigrantes de outros países europeus), com natureza abundante e com a economia em ascensão. No entanto, especificamente no contexto da moda, o mercado ainda não tem um conceito formado sobre a imagem do Brasil. Assim, percebeu-se que os atributos da brasilidade na moda podem ser fonte de vantagem competitiva em transações entre fronteiras, a partir do momento em que forem comunicados e compreendidos pelo mercado internacional. Dentre os oito atributos da imagem do Brasil na moda identificados na literatura, quatro foram destacados como elementos diferenciadores, a saber: forma e volumes, cores, estampas e estilo de vida. Outro resultado do estudo sugere que a oferta de moda no mercado internacional deve ser proposta por meio de uma combinação de elementos distintivos, como: design, qualidade, serviços e suporte e a imagem do país de origem. Assim, entende-se que a imagem do país de origem é um dentre os elementos distintivos que as marcas de moda devem desenvolver em suas ofertas. O estudo contribui ao trabalhar variáveis pouco pesquisadas, colaborando com o conhecimento sobre a imagem do país de origem como fonte de vantagem competitiva no segmento da moda. A investigação contribui também ao sugerir atributos e elementos distintivos que podem ser utilizados para gerar competitividade às empresas de moda que almejam comercializar entre fronteiras. 


\begin{abstract}
The study combines two relevant and current themes: the country of origin image and sources of competitive advantages. Over the last few years Brazil has gained visibility in the international arena, and the international market has shown interest in the Brazilian offering. Therefore the current situation proves timely for companies to develop their offerings to be inserted into foreign markets. Some researches indicate that Brazil conveys the image of a country inhabited by cheerful and welcoming people, with tropical climate and idyllic landscapes. Thus, the present study proposes to understand which country of origin image attributes' represents a source of competitive advantage in the international market.The Brazilian fashion segment was chosen to conduct the study. In order to answer the proposed problem the theoretical framework related to the sources of competitive advantage, the country of origin image, the fashion segment, the Brazilianness and the attributes of Brazilianness in fashion was reviewed. An empirical study of exploratory and qualitative approach was conducted. For data collection, two semistructured interview scripts were elaborated and applied to interview in depth, five support agents of Brazilian fashion to be inserted in international markets (script 1) and four international fashion buyers (script 2).

Data were collected through centered interviews on the problem and analyzed using the discourse analysis technique. The results suggest that Brazil's image is perceived by the international market as a country with hospitable and affective people, with sensual women, which presents a mixed culture (Indians, Africans, Portuguese and immigrants from other European countries), with abundant nature and with a rising economy. However, specifically in the context of fashion, the market has not yet developed the concept of Brazil's Image. Thus, it was realized that the attributes of Brazilianness in fashion can be a source of competitive advantage in cross-border transactions, once they are communicated and understood by the international market. Among the eight attributes of Brazil's image in fashion identified in the literature, four were highlighted as differentiating elements, namely forms and volumes, colors, prints and lifestyle. Another result of the study suggests that fashion offers in foreign markets should be proposed through a combination of distinctive elements, such as design, quality, service and support and the country of origin image. Thus, it is understood that the country of origin image is one of the distinctive elements that fashion brands should develop in their offerings. The study contributes to relate variables that have been little studied in a scientific manner, applying knowledge over the country of origin image as a source of competitive advantage in the fashion segment. The research also contributes by suggesting attributes and distinctive elements that can be used to generate competitiveness for fashion companies that aim to market across borders.
\end{abstract}




\section{SUMÁRIO}

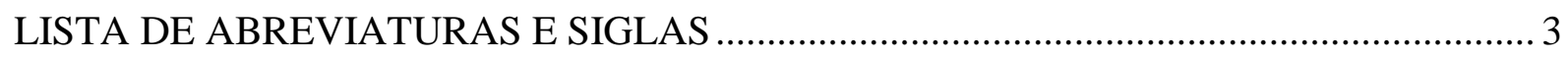

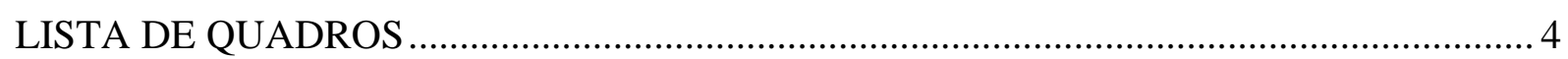

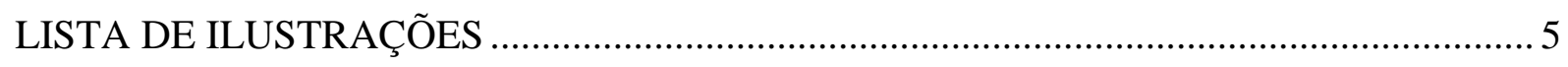

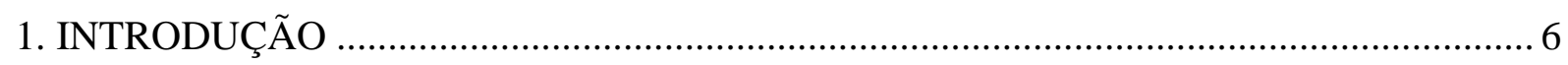

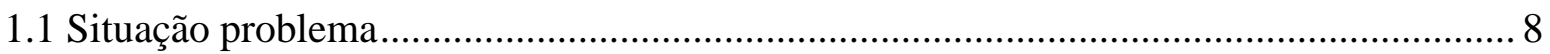

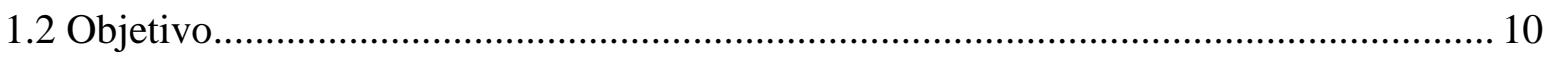

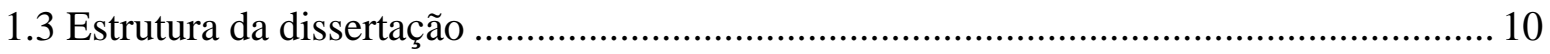

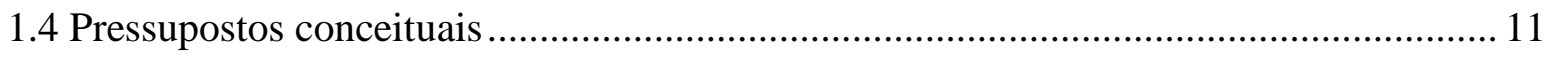

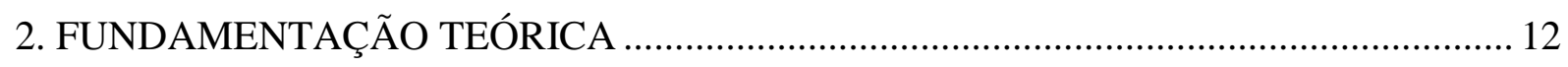

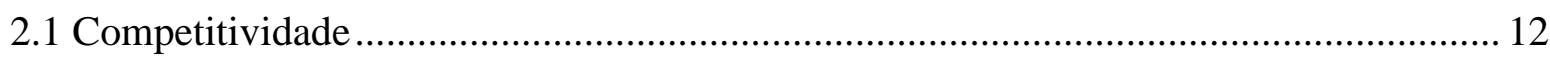

2.1.1 Fontes de Vantagem Competitiva....................................................................... 13

2.1.1.1 Fontes de Vantagem Competitiva Interna ........................................................... 16

2.1.1.2 Fontes de Vantagem Competitiva Externa .......................................................... 16

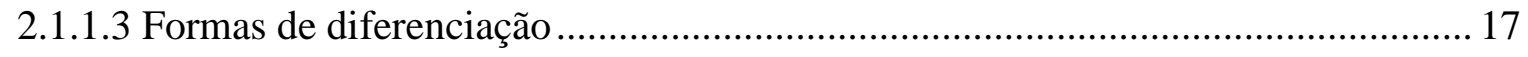

2.1.1.4 Formas de diferenciação no segmento da moda ................................................... 21

2.1.2 A imagem do país de origem como fonte de vantagem competitiva........................ 23

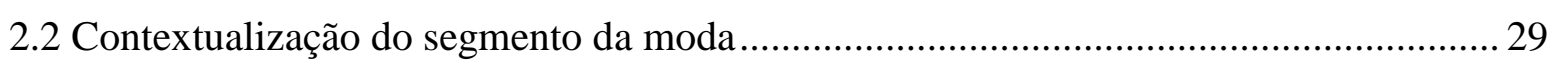

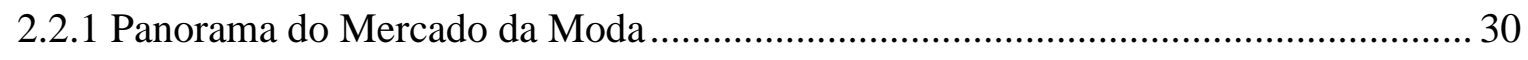

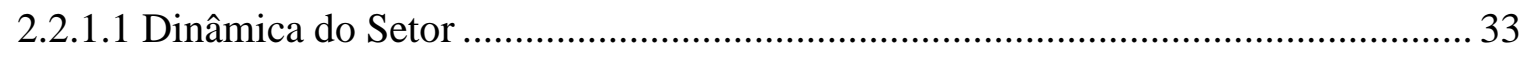

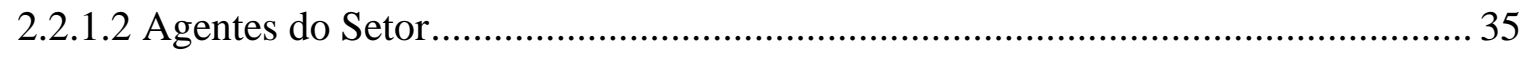

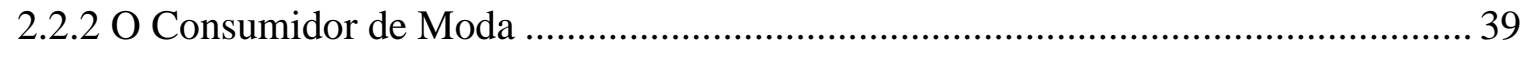

2.2.3 O movimento de internacionalização no segmento do moda ................................... 41

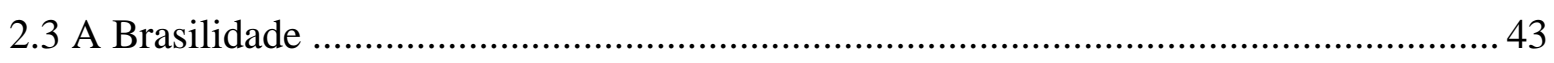

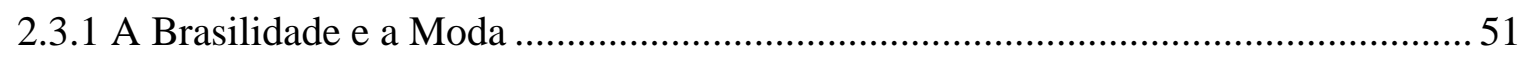

2.3.1.1 A Moda Brasileira e a Brasilidade na Moda......................................................... 52

2.3.1.2 Atributos de Brasilidade na Moda ....................................................................... 58

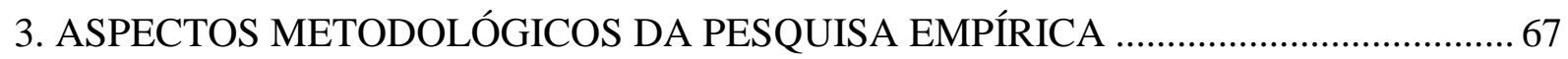

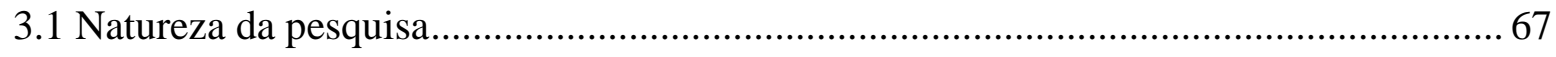

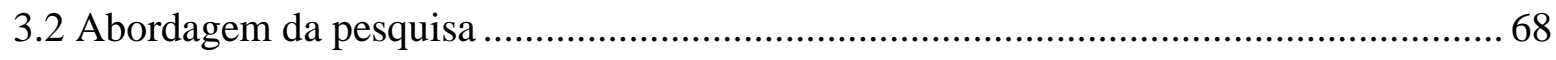

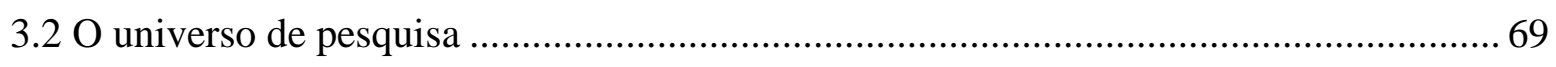

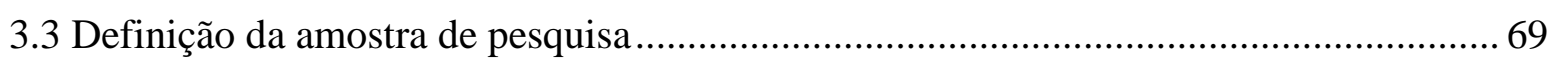

3.4 Definiç̧̃ẽes teóricas e operacionais dos conceitos ..................................................... 70

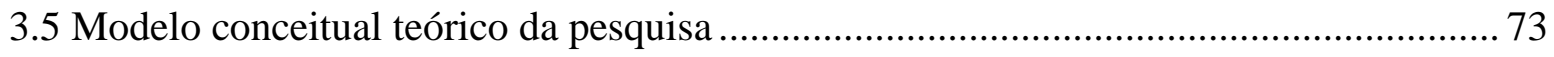

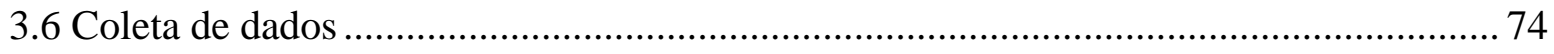

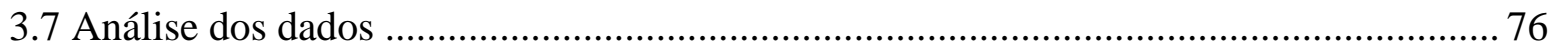




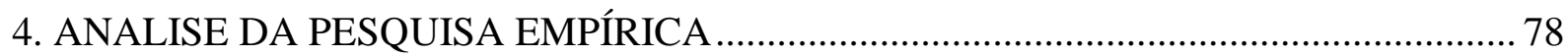

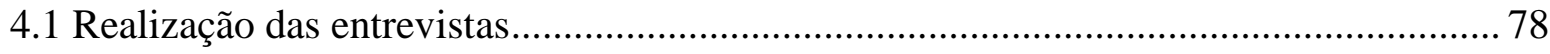

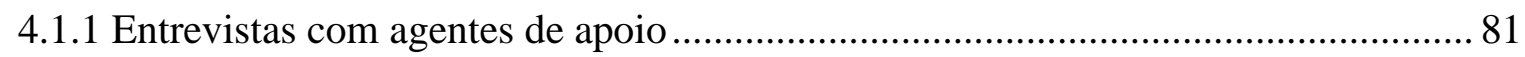

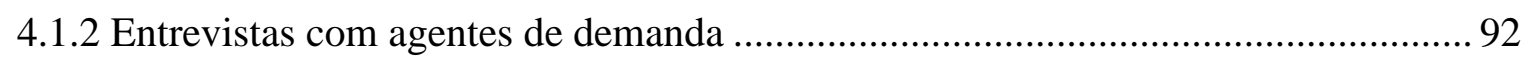

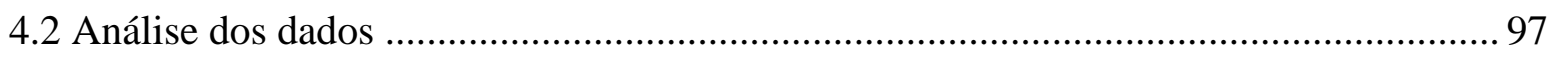

4.2.1 A imagem do país de origem no contexto da moda brasileira.................................. 98

4.2.1.1 A imagem do país de origem e a brasilidade ......................................................... 98

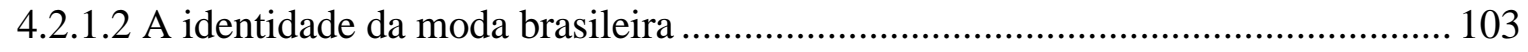

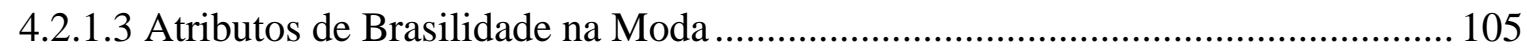

4.2.2 A imagem do país de origem como fonte de vantagem competitiva...................... 110

4.2.2.1 A moda brasileira no mercado internacional ...................................................... 111

4.2.2.2 A apropriação dos atributos da imagem do país de origem na moda ................... 115

4.2.2.3 Formas de diferenciação do produto de moda no mercado internacional ............ 116

4.2.2.4 Entraves à inserção da moda brasileira no mercado internacional ...................... 123

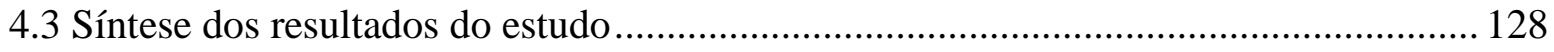

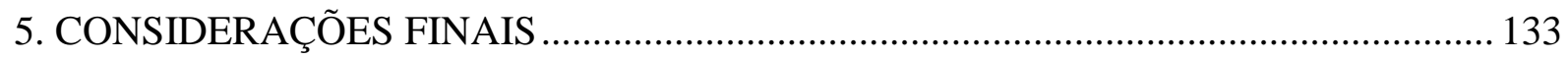

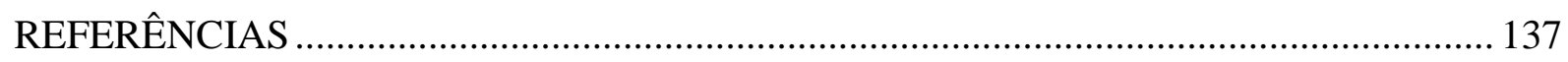

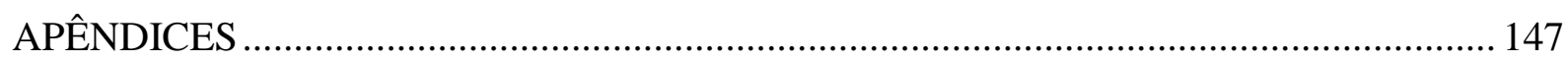




\section{LISTA DE ABREVIATURAS E SIGLAS}

ABEST: Associação Brasileira de Estilistas

ABIT: Associação Brasileira da Indústria Têxtil

APEX-BRASIL: Agência de Promoção de Exportação e Investimentos

BNDES: Banco Nacional do Desenvolvimento

IEMI: Instituto de Estudos e Marketing Industrial

MDIC: Ministério do Desenvolvimento, Indústria e Comércio Exterior

TEXBRASIL: Programa de exportação da indústria da moda brasileira SMB: Sistema Moda Brasil

SEBRAE: Serviço de Apoio às Micro e Pequenas Empresas 


\section{LISTA DE QUADROS}

Quadro 1 - Fontes de Vantagem Competitiva ...................................................................... 28

Quadro 2 - Designers e Marcas de moda que estão se internacionalizando ............................ 37

Quadro 3 - Dimensões da Cultura Brasileira ...................................................................... 49

Quadro 4 - Pontos Positivos e Negativos da Cultura Brasileira segundo pesquisa Cara

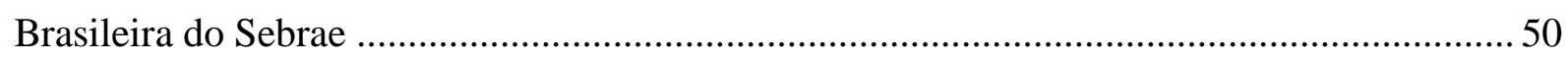

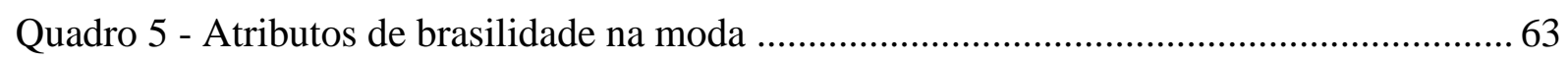

Quadro 6 - Referencias utilizadas na fundamentação teórica .................................................6 65

Quadro 7 - Critérios para seleção de entrevistados por unidade de pesquisa ......................... 70

Quadro 8 - Temas abordados nos roteiros de entrevista ..................................................... 75

Quadro 9 - Síntese dos procedimentos metodológicos da pesquisa empírica .......................... 77

Quadro 10 - Qualificação dos entrevistados ..................................................................... 79

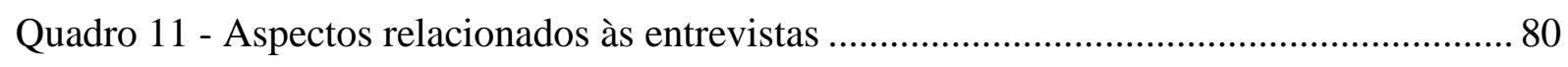

Quadro 12 - Dimensões e sub-dimensões da análise de dados ............................................ 97

Quadro 13 - Elementos da Imagem do País de Origem ......................................................... 102

Quadro 14 - Atributos de Brasilidade na Moda na ótica dos entrevistados ........................... 109

Quadro 15 - Formas de distinção de oferta ....................................................................... 117

Quadro 16 - Formas de diferenciação da oferta de moda no entendimento dos entrevistados

Quadro 17 - Entraves à internacionalização da moda brasileira ......................................... 124

Quadro 18 - Entraves à internacionalização da moda brasileira segundo os entrevistados ... 127

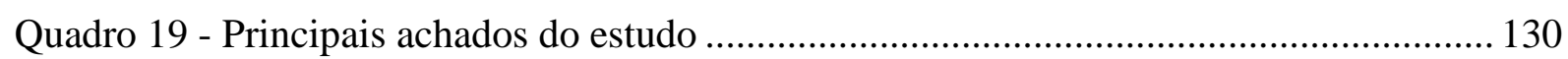




\section{LISTA DE ILUSTRAÇÕES}

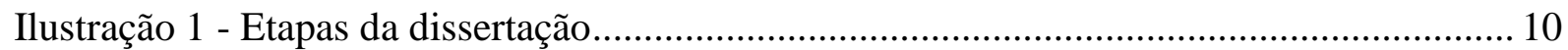

Ilustração 2 - Estrutura da Fundamentação Teórica................................................................. 12

Ilustração 3 - Elementos da Vantagem competitiva.............................................................. 15

Ilustração 4 - Estratégias de Diferenciação de Mintzberg...................................................... 17

Ilustração 5 - Regulação do mercado de moda ................................................................... 34

Ilustração 6 - Modelo conceitual teórico da pesquisa ............................................................... 74 


\section{INTRODUÇÃO}

A partir da década de 1980, a competição em grande parte dos domínios econômicos, como, por exemplo, nos Estados Unidos, nos países europeus e latinos, passou a ser cada vez mais intensa. Esse contexto é decorrente das mudanças constantes e de fenômenos como a integração de mercados e a evolução tecnológica, que quebram barreiras de comunicação, aproximam agentes de mercado em busca de pares que possam oferecer melhores condições em transações comerciais, tendo como um dos resultados a intensificação da concorrência nos mercados .

Nesse ambiente, a indústria têxtil passou e passa por diversas reestruturações que se intensificaram desde o final da década de 1980, como, por exemplo, a modernização do parque industrial e o aperfeiçoamento tecnológico (BRAGA, 2008). Até essa década os produtos brasileiros eram protegidos contra os importados por meio de salvaguardas. Já em 1990, ainda no Governo do ex-presidente Fernando Collor, a medida de redução das taxas de importação sem políticas internas que preparassem os empresários brasileiros a competir num mercado mundial renovado e dinâmico, com oponentes que já tinham apoio de seus governos com práticas de incentivo à exportação, resultou na falência de grandes empresas (AVELAR, 2009).

Apesar dos avanços estruturais e do fim da crise da década de 1990, percebe-se que a cadeia produtiva da moda brasileira está inserida em um mercado bastante competitivo (RECH, 2008). Essa cadeia é composta por três elos - fibras e filamentos, têxtil (fiação, tecelagem plana, malharia e beneficiamento) e confecção (vestuário, linha lar e técnicos) (IEMI, 2011). O segmento de mercado pesquisado pelo estudo é o do vestuário, que faz parte do elo da confecção, e tem como objeto central os produtos de moda desenvolvidos por marcas e por designers brasileiros.

Para competir em tal segmento, é necessário que se entendam as principais peculiaridades dessa indústria, que é caracterizada pela duração efêmera de suas coleções e renovação constante dos produtos ofertados. Tais características podem ser compreendidas por meio da dinâmica dessa indústria, a qual se apoia na promoção dos produtos de moda ao utilizar a previsão de tendências e enfatizar um ciclo rápido de vida dos produtos, permitindo que o 
segmento tenha contínuo crescimento e se desenvolva como as demais indústrias (ROCHA, HAMMOND, HAWKINS, 2005).

O ciclo rápido, ou mudança de moda, é compreendido como a obsolescência planejada promovida por varejistas de moda que buscam motivar os consumidores a comprar novas roupas constantemente (LAW, ZHANG, LEUNG, 2004). Com isso, tal segmento se desenvolve por meio de ciclos semestrais de tendências em que as cores, estilos, texturas variam rapidamente (FEGHALI, 2004). Tais ciclos acontecem, no mínimo, duas vezes por ano, coleções de inverno e de verão (BRAGA, 2005).

Para que os ciclos de moda aconteçam e para que as trocas se realizem, a indústria da moda, assim como qualquer outra indústria, depende da participação e ação de atores de mercado. Assim, os agentes ofertantes - que são as empresas, as marcas e designers de moda - com o apoio de associações, instituições e pesquisadores, desenvolvem conceitos e produtos de moda com intuito de suprir os anseios dos consumidores. Por outro lado, os agentes demandantes são representados pelos canais de distribuição, ou seja, por distribuidores, atacadistas, varejistas e consumidores finais que compram produtos de moda.

Por sua vez, os consumidores destes produtos são influenciados por benefícios e buscam expressar e construir sua personalidade por meio da moda (RYBALOWSKI, 2008). As motivações de compra nesse setor são emocionais e racionais, podendo variar de consumidor para consumidor, sendo as principais: para estar na moda; para se sentir atraente; para impressionar aos outros; para ser aceito no grupo e, para suprir uma necessidade emocional (FEGHALI, 2008; FRINGS, 2001).

Logo, para cativar e fidelizar os consumidores de moda, as empresas devem sustentar sua oferta com base na diferenciação, podendo fazer a distinção por imagem, suporte/serviço, qualidade, design, sustentabilidade ou inovação (MINTZBERG, 2006; KOTLER, KELLER, 2006; ORSATO, 2006; KING, LENOX, 2001; ELKINTON, 1994; WEN-CHENG, CHIEN_HUNG, YING-CHIEN, 2011; DANSKIN, ENGLIS, SOLOMON, GOLDSMITH, DAVEY, 2005). Destaca-se, na competição em mercados internacionais, o uso da imagem do país de origem como uma fonte de distinção da oferta (FINESTRALI; GARRIDO, 2010; GIRALDI; TORNAVOI, 2004; 2005). 
No mercado de moda especificamente, evidencia-se a diferenciação por meio: da sustentabilidade nos processos e no produto (KIKUCHI, SILVA, 2011; ROCHA et al., 2005; EMERENCIANO, PIRES, 2006); pela inovação, de produto e processos (ZATTA, CRISHNA, MENEZES, 2011; DANSKIN et al., 2005; RYBALOWSKI, 2008); pela imagem (ZATTA et al., 2011; BRÏDSON, EVANS, 2004), e pelo design, que abrange a qualidade, o estilo, a inovação e os aspectos artesanais do produto (RYBALOWSKI, 2008) e versa ainda, sobre a arte no produto (KIKUCHI, SILVA, 2011) e a sua identidade (ZATTA et al., 2011). Por isso, algumas empresas brasileiras estão buscando utilizar estratégias com foco na comercialização de produtos de moda diferenciados para valorizar suas marcas em transações entre fronteiras (VICENTE, 2009).

\subsection{Situação problema}

No segmento da moda, a abertura do mercado brasileiro - que se iniciou no governo Fernando Collor de Mello na década de 1990 - teve como consequência o acirramento da concorrência internacional, demandando que as empresas desse segmento redefinissem suas estratégias competitivas (COSTA, ROCHA; 2009). Nessa época, o Brasil ainda não incentivava a cultura de criação, pois as marcas de moda costumavam adaptar modelos de vestes do mercado internacional.

Uma alternativa que passou a ser utilizada por muitas empresas do segmento da moda foi a de buscar referências nos estereótipos da brasilidade (MESSIAS, 2009). Assim, elementos que remetem à cultura brasileira como, por exemplo, o artesanato, passaram a ser utilizados por designers e marcas, representando o ponto de partida para a produção da moda feita no Brasil com diferencial (VILLAÇA, 2007).

A partir da busca de referências em elementos de brasilidade para desenvolvimento de coleções, designers e marcas brasileiras passaram a incorporar atributos de brasilidade em suas coleções, como, entre outros, Tufi Duek, Lino Villaventura, Osklen, Ronaldo Fraga, Gilson Martins e Isabela Capeto.

Assim, os atributos da imagem do país de origem no contexto da moda, denominado neste estudo como atributos de Brasilidade na moda, abarcando as representações do Brasil e 
símbolos nacionais; cores; matérias primas naturais; aplicações e técnicas artesanais; estilo de vida do brasileiro; estampa; formas e cores, que emergem como potenciais elementos diferenciadores podem ser incorporados em produtos e marcas de moda, podendo ainda, representar fonte de vantagem competitiva no mercado internacional.

O Brasil esta ganhando visibilidade no mercado internacional em função da realização da Copa do Mundo em 2014 e Olimpíadas em 2016. Assim, o momento mostra-se oportuno para as empresas brasileiras que vislumbrem competir entre fronteiras utilizarem e potencializarem as referências de brasilidade em suas ofertas (produto e serviço). Para competir no mercado de moda internacional destaca-se a importância das empresas desenvolverem estratégias competitivas baseadas na diferenciação em função de tal mercado ser caracterizado pela intensa competitividade e forte presença dos países asiáticos (COSTA; ROCHA, 2009), reforçando-se assim, a importância da utilização de atributos da brasilidade em ofertas.

No entanto, o segmento da moda no Brasil ainda está buscando construir raízes brasileiras a partir de narrativas explicitas que fazem parte do imaginário nacional e internacional sobre a sociedade e o povo brasileiro (LEITÃO, 2009). No âmbito acadêmico, a pesquisa em moda ainda encontra-se em estágio inicial. De acordo com Bonadio (2010), a primeira faculdade de moda foi estruturada em 1987, e os eventos científicos começaram a fazer parte da rotina dos acadêmicos da moda somente a partir dos anos 2000, década em que os primeiros eventos científicos começaram a ser realizados anualmente.

Desse modo, o estudo almejou compreender os atributos que compõem a imagem do país de origem no contexto da moda brasileira no âmbito internacional sob a ótica de profissionais de associações e instituições que apoiam a inserção da moda brasileira no mercado internacional e compradores internacionais. Procurou também identificar quais atributos são reconhecidos e valorizados pelos agentes de mercado. Em função desse interesse, serão consideradas as variáveis que foram pouco estudadas de forma científica (conforme consulta em base de dados realizada pela Autora), a saber: imagem do país de origem, segmento da moda, Brasilidade na moda, fontes de vantagem competitiva e mercado internacional. Com isso, buscou-se responder a seguinte questão-problema: Quais atributos da imagem do país de origem representam fonte de vantagem competitiva no mercado internacional? 


\subsection{Objetivo}

Compreender quais atributos da imagem do país de origem representam fonte de vantagem competitiva no mercado internacional, no contexto da moda brasileira.

\subsection{Estrutura da dissertação}

Para atingir o objetivo de pesquisa desta dissertação, desenvolveram-se cinco etapas, conforme apresentado na ilustração 1.

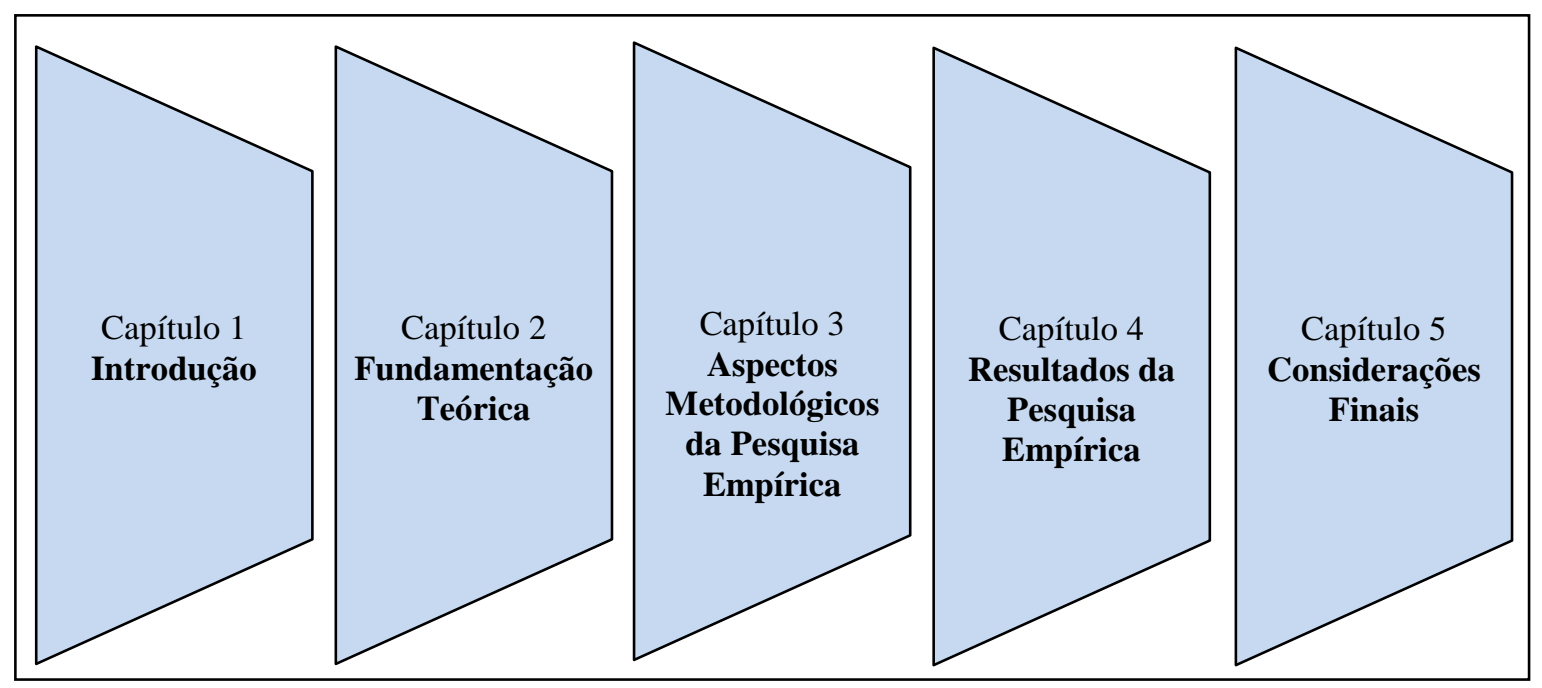

Ilustração 1 - Etapas da dissertação

O capítulo 1 contempla a parte introdutória do estudo onde podem ser identificados aspectos referentes à contextualização da pesquisa e a questão problema, assim como o objetivo da pesquisa.

Para responder ao problema de proposto, realizou-se uma pesquisa bibliográfica, apresentada no capítulo 2, a qual alicerçou o estudo empírico. A fundamentação teórica centrou-se nos seguintes assuntos: fontes de vantagens competitivas, imagem do país de origem, o segmento da moda e a brasilidade.

Realizou-se uma pesquisa empírica de caráter qualitativo e natureza exploratória, buscando responder as seguintes questões de pesquisa: Q1) Quais os atributos que compõem a imagem país de origem no segmento da moda brasileira? Q2) Quais os atributos da imagem país de 
origem na moda brasileira que são reconhecidos, valorizados e utilizados pelos agentes do segmento? Os procedimentos metodológicos utilizados na pesquisa, o método de coleta e análise dos dados, a amostra e os instrumentos utilizados foram detalhados no capítulo 3.

Os resultados obtidos com a pesquisa empírica foram apresentados e discutidos no capítulo 4. Nesse capítulo, os achados obtidos por meio dos relatos dos agentes de mercado do segmento da moda foram apresentados e comparados com os apontamentos encontrados na fundamentação teórica.

No capítulo 5, foram apresentadas as considerações finais, assim como as limitações e sugestões de estudos futuros, seguido das referências consultadas e apêndices do estudo.

\subsection{Pressupostos conceituais}

As seguintes considerações são tidas, para fins desse estudo, como pressupostos conceituais:

a) As empresas do segmento da moda brasileira (designers e marcas), assim como em outros segmentos, desenvolvem suas atividades alicerçadas em estratégias de crescimento e estratégias competitivas. Acredita-se que uma das estratégias de crescimento que tem sido utilizada por marcas e designers é a de internacionalização e, como estratégia competitiva, tem-se focado na diferenciação da oferta.

b) O movimento de internacionalização no segmento de moda é recente e intensificou-se com incentivo do governo brasileiro que, em 2000, viabilizou a criação do TexBrasil (Programa de Exportação da Indústria da Moda Brasileira), por meio de uma parceria entre a Apex-Brasil (Agência de Promoção de Exportação e Investimentos) e a Abit (Associação Brasileira da Indústria Têxtil de Confecção). Tal projeto tem como objetivo dar suporte às empresas do setor de moda interessadas na inserção de seus produtos em outros mercados. Assim, o produto de moda brasileira ainda não se posicionou no mercado internacional de forma consolidada. 


\section{FUNDAMENTAÇÃO TEÓRICA}

Nesse capítulo serão abordados os conceitos teóricos que nortearam a pesquisa de campo. $\mathrm{O}$ capítulo está dividido em três partes, sendo que a primeira parte trata sobre as fontes de vantagem competitiva, a segunda parte sobre o mercado em estudo e, a parte final, apresenta a literatura referente à brasilidade na moda conforme pode ser observado na ilustração 2.

\section{Fundamentação teórica}

Competitividade e Fontes de Vantagens competitivas: buscou-se apresentar as principais fontes de vantagens competitivas encontradas na literatura, formas de diferenciação e modelos de competitividade que podem ser utilizados pelas empresas na busca por vantagens competitivas, assim como, formas de diferenciação apresentadas em estudos acadêmicos no campo da moda. Identificouse que uma das fontes está diretamente relacionada ao problema de pesquisa proposto, a diferenciação por meio da imagem país de origem.

Panorama do segmento da moda: delinaram-se as principais características do segmento em estudo, o que proporcionou conhecimento sobre a dinâmica deste mercado e seus agentes para definição do universo da pesquisa empírica.

Brasilidade: apresentaram-se as principais definições sobre o constructo da Brasilidade, a evolução do conceito, assim como, contextualizou-se a Brasilidade no segmento da moda. Tal conhecimento alicerçou o desenvolvimento do roteiro de entrevista da pesquisa empírica.

\section{Ilustração 2 - Estrutura da Fundamentação Teórica}

\subsection{Competitividade}

Conforme mencionado anteriromente, há algumas décadas a competição era praticamente inexistente em muitos países e setores (PORTER, 1999). As empresas focavam seus esforços na produção e no produto até o momento em que a oferta passou a ser superior que a demanda, assim, a competição entre os agentes de mercado pela preferência do consumidor tornou-se parte da dinâmica de mercado e as empresas passaram a buscar entender os anseios dos consumidores.

Com isso as empresas passaram a ter que formular suas estratégias, passando a considerar os novos concorrentes e também os novos mercados em que poderiam desenvolver suas atividades. Seguindo essa dinâmica, a preferência dos consumidores passou a ser disputada 
não só por empresas locais, mas, também, por multinacionais estrangeiras que começaram a desenvolver suas operações em novos mercados.

O mercado brasileiro também está inserido nesse processo de evolução competitiva e até o final da década de 1980 era caracterizado por indústrias que tinham uma posição competitiva de relativa comodidade (ZATTA et al., 2011). Porém, a partir de 1990, com a abertura comercial, promovida pelo governo do então presidente Fernando Collor, as empresas passaram a não limitar seu crescimento às tradicionais bases de clientes (ZATTA et a.l, 2011).

Desse modo, o contexto competitivo atual obriga as organizações a buscarem alternativas estratégicas que acelerem o crescimento de suas operações, assim como as diferencie da concorrência e que as apoie no sentido de manter sua posição competitiva vantajosa. Almejando tais objetivos, muitas empresas optam pelo crescimento por meio do desenvolvimento de novos mercados, passando a produzir e comercializar em outros países, intensificando ainda mais o movimento de integração de mercados. De acordo com Bruno, Filipecki e Júnior (2009, p. 3), “competir por mercados mais exigentes capacita as empresas a oferecer melhores produtos para seus mercados tradicionais".

Além da estratégia de crescimento, a empresa deve escolher uma estratégia competitiva para obtenção de uma posição vantajosa frente aos competidores. Várias são as formas apontadas na literatura para a obtenção de vantagem competitiva, podendo ser de origem interna e ou externa à organização, com base nos processos e ou na oferta, como se verá no item seguinte.

\subsubsection{Fontes de Vantagem Competitiva}

Para que as empresas consigam atingir o crescimento almejado diante do contexto mercadológico atual, os agentes empresariais devem optar por estratégias de crescimento, assim como devem escolher uma estratégia competitiva para obtenção de uma posição vantajosa frente aos competidores (ANSOFF, 1990).

A estratégia de crescimento versa sobre a definição do escopo de atuação da empresa, ou seja, seus negócios, produtos e mercados, e o escopo vertical ou grau de integração na cadeia de 
valor da indústria (TOLEDO; ANSELMO, 2003). A estratégia de crescimento também abrange as formas da empresa obter seus objetivos, podendo ser via desenvolvimento interno, aquisições e/ou fusões, e alianças estratégias (TOLEDO; ANSELMO, 2003). Já a estratégia competitiva consiste na escolha de uma dentre as alternativas que as empresas dispõem liderança de custos ou diferenciação (PORTER, 1989) - para alcançar e manter uma vantagem competitiva no mercado (TOLEDO; ANSELMO, 2003). Assim, entende-se se que a vantagem competitiva que uma empresa pode obter está relacionada à estratégia competitiva utilizada pela organização para desenvolver suas atividades.

De acordo com Barney e Hesterly (2007), uma empresa consegue obter uma vantagem competitiva quando é capaz de gerar valor econômico superior ao de seus concorrentes. De acordo com esses autores, o valor econômico consiste na diferença entre os benefícios percebidos pelo consumidor relacionados à compra de produtos/serviços de uma organização e o custo de produção e comercialização de tais produtos/serviços.

Seguindo o mesmo raciocínio, Wen-Cheng et al. (2011) apontam que a vantagem competitiva de uma empresa se dá quando a organização é capaz de entregar os mesmos benefícios que seus competidores mas com custos menores (vantagem de custo), ou entrega benefícios que excedem os disponibilizados pelos seus concorrentes (vantagem por diferenciação). Desse modo, Lambin (2000), afirma que a vantagem competitiva ocorre quando a empresa apresenta características ou atributos em seus produtos ou marca que lhe conferem certa superioridade em face aos concorrentes imediatos, podendo, tais atributos serem próprios do produto ou decorrentes de serviços necessários ou agregados, ou ainda referentes aos modos de produção, distribuição ou venda do produto pela empresa.

Porter (1989) pondera que uma empresa, para obter vantagens competitivas, deve optar por um dentre os dois tipos básicos de vantagem competitiva existente, por meio do: baixo custo ou diferenciação. Nesse sentido, a opção estratégica adotada pela empresa (liderança de custos ou diferenciação), com intuito de criar e capturar valor, demanda a escolha de uma forma de atuação no mercado que se apoie em, pelo menos, uma fonte de vantagem competitiva.

Day e Wensley (1988) seguem os apontamentos de Porter (1989) ao considerarem de fundamental importância a empresa optar por uma das posições competitivas (diferenciação 
ou liderança de custos) para se posicionar de forma superior no mercado. No entanto, acrescentam à discussão, a necessidade de se ter habilidades e recursos superiores aos do concorrente e citam que a criação e a sustentação de uma vantagem competitiva é resultado de um processo cíclico, conforme ilustração 3.

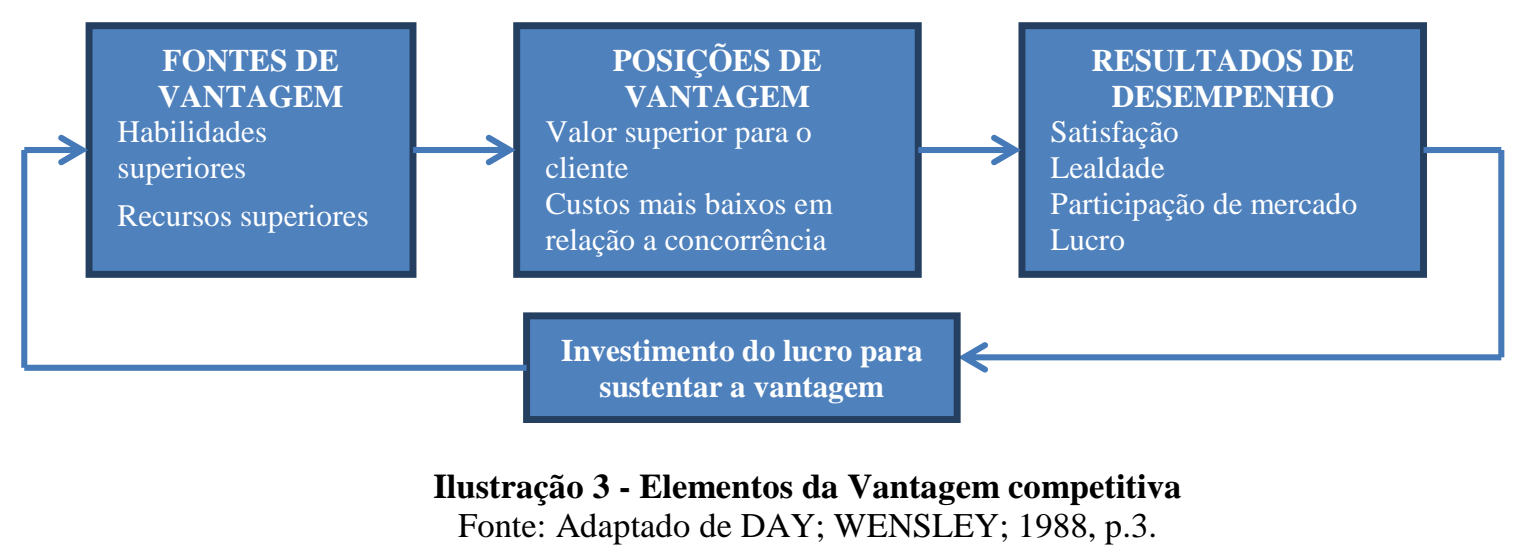

Cater (2003) aponta, assim como citado por Porter (1989), que a literatura científica discute duas formas fundamentais de vantagem competitiva (liderança de custos e diferenciação). No entanto, para Cater (2003), há quatros escolas que apontam fontes de vantagem competitiva: a escola da organização industrial, a escola da visão baseada em recursos, a escola baseada em capacidades e a escola baseada em conhecimento.

Wen-Cheng et al. (2011), não fazem distinção entre a origem das vantagens competitivas, somente defendem que a vantagem competitiva tem origem na tecnologia e inovação; nos recursos humanos e na estrutura organizacional. No entanto, Orsato (2006) afirma que a identificação de fontes de vantagem competitiva demanda que se faça uma distinção clara entre produtos/serviços e o processo organizacional.

Posto isso, compreende-se que as vantagens competitivas podem ter origem externa ou interna à organização e dependem da estratégia competitiva adotada pela empresa (LAMBIN, 2000; BARNEY, 1991; WEN-CHENG et al., 2011; PORTER, 1989). Nesse sentido, observase na literatura, como se verá adiante, que as fontes de vantagem competitiva interna referemse aos processos organizacionais, enquanto as fontes externas fazem referência aos atributos de produtos e serviços. 


\subsubsection{Fontes de Vantagem Competitiva Interna}

De acordo com Lambin (2000) a vantagem competitiva é interna quando se apoia na superioridade da empresa com relação à sua matriz de custos de produção, de gestão do produto, superioridade essa que gera valor ao produtor uma vez que seu nível de custos é inferior ao de seus concorrentes. Esse autor complementa que a vantagem competitiva interna é resultado da melhor produtividade, atribuindo à empresa uma maior rentabilidade e capacidade de resistir à queda de preços que pode ser imposta pelo mercado.

Nesse sentido, uma vantagem competitiva interna pode ser obtida por meio da utilização da estratégia de liderança pelos custos, a qual esta diretamente relacionada ao saber-fazer organizacional e aos recursos tecnológicos empregados pela empresa. De acordo com Porter (1989), quando uma empresa opta pela estratégia de liderança de custos - em que a empresa foca seus esforços para tornar-se o produtor de baixo custo em sua indústria - as vantagens de custos são conquistadas por meio da busca de economia de escala, do acesso preferencial a insumos, tecnologia patenteada entre outros.

Outra fonte de vantagem competitiva interna é apontada na literatura por Barney (1991); Barney e Hesterly (2007), por Lambin (2000) e Saes (2008), apoiando-se na utilização da visão baseada em recursos, nas políticas e práticas da empresa. Tal visão argumenta que a obtenção de vantagens competitivas emerge a partir da identificação, desenvolvimento e gestão do portfólio de recursos físicos, financeiros, intangíveis, organizacionais e humanos. Esse processo resulta no desenvolvimento de competências e recursos internos que asseguram uma posição competitiva sustentável, pois seus competidores não conseguem imitar esses recursos (BARNEY; 1991; BARNEY; HESTERLY, 2007; SAES, 2008).

\subsubsection{Fontes de Vantagem Competitiva Externa}

A vantagem competitiva é externa quando se alicerça em qualidades diferenciadoras do produto as quais geram valor para o comprador em função: 1) do aumento do seu desempenho de uso ou 2) pela diminuição dos seus custos de utilização (LAMBIN, 2000). Desse modo, essa fonte de vantagem competitiva, permite que a empresa adote um preço de venda superior ao da concorrência (LAMBIN, 2000). Tal afirmação corrobora com o proposto por Porter 
(1989) de que uma das formas de uma empresa obter vantagem competitiva se dá por meio da diferenciação de produtos/serviços, em que a empresa busca oferecer produtos/serviços de valor singular para os compradores.

A vantagem competitiva externa concede à empresa um poder de mercado superior, uma vez que o seu emprego faz com que o mercado aceite o preço de venda superior ao do concorrente que não oferece atributos diferenciadores (LAMBIN, 2000). Nesse sentido, uma estratégia competitiva baseada em uma vantagem competitiva externa é utilizada quando a empresa adota a estratégica competitiva de diferenciação. Tal estratégia, conforme aponta Lambin (2000), está relacionada à forma de atuação do marketing, ou seja, à sua capacidade de identificar e satisfazer as expectativas dos consumidores que ainda não estejam satisfeitos com os produtos oferecidos pela concorrência. Para Porter $(1989$, p.12) a diferenciação pode ser fundamentada "no próprio produto, no sistema de entrega do produto, no método de marketing e em uma grande variedade de outros fatores". Com isso, faz-se necessário relacionar e compreender as formas de diferenciação que podem ser utilizadas pelas empresas.

\subsubsection{Formas de diferenciação}

De acordo com Mintzberg (2006) uma empresa pode se distinguir em mercados competitivos, por meio da diferenciação das suas ofertas de alguma maneira, visando diferenciar seus produtos e serviços dos produtos e serviços de seus oponentes. $\mathrm{O}$ autor sugere seis maneiras básicas de diferenciar as ofertas, detalhando a estratégia de diferenciação de Porter, expressas na ilustração 4.

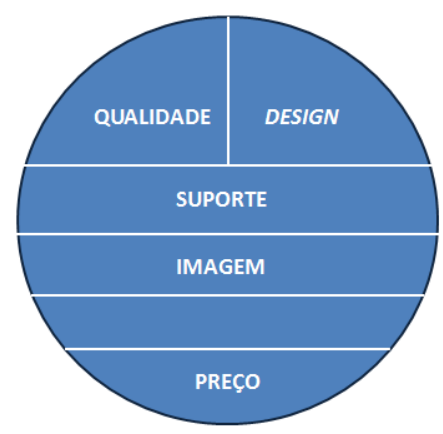

Ilustração 4 - Estratégias de Diferenciação de Mintzberg. Fonte: MINTEZBERG; 2006.

A primeira forma de diferenciação apontada por Mintzberg (2006) é a por preço. Esse tipo de 
diferenciação é considerado o mais básico, consistindo, simplesmente, em cobrar um preço inferior pelo produto ofertado, podendo ser aplicada em casos em que o produto não é diferenciado (commodity ou produto com design). Nessa forma de diferenciação, o produtor absorve a perda da margem de lucro ou aumenta a massa de lucro, mas com a mesma margem em função da venda em maior escala. Entende-se, nesse caso, que a fonte de vantagem competitiva passaria a ser interna, por meio da estratégia de liderança de custos e não pela diferenciação.

A segunda forma de diferenciação apontada pelo autor é a não diferenciação, ou seja, a empresa opta pela estratégia de não se diferenciar. No entanto, neste estudo as duas primeiras formas de diferenciação propostas por Minztberg (2006) (por preço e não diferenciação) não serão consideradas como opções de distinção, uma vez que essas formas de distinção enquadram-se na estratégia de custos de Porter (1989).

A terceira forma de diferenciação proposta por Mintzberg (2006) é por imagem, sendo desenvolvida por meio do marketing. Segundo o autor, o marketing comunica a diferenciação criando uma imagem. Logo, o autor defede que cria-se uma imagem para que o produto aparente ser diferenciado.

Já a diferenciação por suporte, não interfere no produto em si, é mais substancial. Significa diferenciar com algo que esteja junto ao produto com base em suporte. Pode abarcar a venda do produto (crédito especial ou entrega 24 horas, por exemplo), atendimento (serviço pós venda excepcional), ou fornecimento de um produto ou serviço relacionado ao produto básico adquirido (MINTZBERG, 2006).

Outra forma de diferenciação apontada por Mintzberg (2006) é a por qualidade. Esta maneira de diferenciação está ligada as características do produto que o tornam melhor, ou seja, um produto que tenha: 1) maior confiabilidade; 2) maior durabilidade ao longo do tempo e 3) performance superior.

A sexta forma de diferenciação sugerida pelo autor é a por design. A qual versa sobre a diferenciação com base no design do produto, ou seja, consiste em oferecer algo que realmente se diferencie de um produto cujo design seja dominante, por meio de características únicas. 
Kotler e Keller (2006) também detalham as formas de diferenciação. Para tais autores a diferenciação está relacionada com os aspectos do produto ou serviço, mas apontam que em mercados competitivos as empresas precisam se empenhar mais e devem utilizar outras dimensões para diferenciar seu produto, como funcionários, canais e imagem.

Logo, Kotler e Keller (2006) abordam cinco formas de diferenciação: 1) baseada no produto; 2) baseada nos funcionários; 3) baseada nos serviços; 4) baseada no canal, e 5) baseada na imagem.

- Diferenciação baseada no produto: Kotler e Keller (2006) defendem que para uma marca ter identidade deve oferecer produtos diferenciados, assim, as empresas buscam novas dimensões para a diferenciação. Nesse sentido, o produto pode se diferenciar por meio: da sua forma (tamanho, estrutura física ou formato); de suas características (características variáveis, contemplando a função básica, podendo oferecer pacotes de características); qualidade de desempenho (nível no qual as características básicas do produtos operam); qualidade de conformidade (quando os compradores esperam que todas as unidades produzidas que sejam idênticas atendam às especificações prometidas); durabilidade (mensuração da vida operacional esperada do produto); confiabilidade (mensuração da probabilidade de um produto não apresentar defeitos ou quebrar); facilidade de reparo (mensuração da facilidade de consertar o produto que deixe de funcionar ou que esteja funcionando mal), e o estilo (visual do produto e a sensação que este transmite ao comprador).

Kotler e Keller (2006) destacam ainda, na diferenciação de produto, a importância do design de produto em mercados em que a concorrência é intensa e a tecnologia e o preço não se mostram atributos suficientes para diferenciar a oferta; por isso, apontam que o design é um fator que proporciona constantemente a vantagem competitiva. Para esses autores o design consiste no conjunto de características que influenciam na aparência e no funcionamento do produto sob o entendimento das exigências do cliente. Esse atributo se faz de particular importância na elaboração e comercialização de roupas.

- Diferenciação baseada em funcionários: de acordo com Kotler e Keller (2006), uma empresa pode obter fonte de vantagem competitiva ao manter sua equipe bem treinada. Tal apontamento remete à fonte de vantagem competitiva interna por meio da Visão Baseada em Recursos (BARNEY, 1991), conforme mencionado anteriormente. 
- Diferenciação baseada em serviços: é uma alternativa quando o produto não pode ser facilmente diferenciado. Kotler e Keller (2006, p. 372) apontam que a adição de serviços valorizados ao produto pode ser "a chave para o sucesso competitivo". Os elementos que compõem a diferenciação por serviços são: a facilidade do pedido (facilidade que o cliente encontra para realizar o seu pedido à empresa); entrega (qualidade com que o produto é entregue ao cliente, incluindo velocidade, precisão e a preocupação com o processo); instalação (trabalho realizado para tornar um produto operacional no local desejado pelo cliente); treinamento do cliente (capacitar os funcionários do cliente para que estes utilizem o equipamento da maneira correta e apropriada para ter eficiência); orientação ao cliente e manutenção e reparo.

- Diferenciação baseada no canal: forma de distribuição que pode conferir vantagem competitiva mediante a cobertura, a especialidade e o desempenho dos canais de distribuição de uma empresa (KOTLER, KELLER, 2006).

- Diferenciação baseada na imagem: para entender a diferenciação por imagem, faz-se necessário compreender o conceito de identidade e de imagem. O primeiro consiste na forma como a empresa busca identificar ou posicionar seu produto e sua marca, já a imagem, referese ao modo como o público avalia a empresa e seus produtos. Logo, uma identidade eficaz deve (1) estabelecer a personalidade do produto e a proposta de valor, (2) comunicar a personalidade da marca de forma distinta e (3) deve difundir esta por todos os tipos de comunicação, de modo que a imagem da empresa reflita a sua identidade (KOTLER, KELLER, 2006).

Danskin et al. (2005) citam que existem duas formas primárias de estratégia de diferenciação: 1) a diferenciação com base no mercado - que ocorre quando a empresa busca se destacar da concorrência por meio do posicionamento do produto e o faz monitorando a concorrência para diferenciar seus produtos e serviços de seus oponentes; e 2) a diferenciação baseada na inovação - em que a empresa procura se diferenciar mediante a utilização de tecnologia inovadora para satisfazer as necessidades dos clientes.

Para Wen-Cheng et al. (2011) inovação pode ocorrer no produto, serviço e nos processos, sendo que a inovação de produto consiste em disponibilizar ao mercado produtos que são percebidos como novos tanto pelo consumidor quanto pelo produtor. A empresa que se 
caracteriza como inovadora busca a contínua melhoria de seus produtos, serviços e o modo como operacionalizam seus processos (WEN-CHENG et al., 2011). Com isso, pode-se entender que a inovação é uma fonte de vantagem competitiva interna quando se dá em processos, e externa quando se refere a produtos e serviços.

King e Lenox (2001), citam que as empresas podem possuir recursos únicos ou capacidades que possam lhes permitir implementar estratégias ambientais rentáveis que sejam difíceis de serem imitadas. Nesse sentido, a sustentabilidade também figura como uma fonte de vantagem competitiva, por meio da diferenciação que é reforçada pela crescente valorização atribuída pelo consumidor à proteção ambiental (ORSATO, 2006; ELKINTON, 1994). Na década de 1990, Elkinton (1994) já mencionava que uma das tendências ambientais mais relevantes dos últimos tempos era a busca por produtos ecológicos por parte dos consumidores, o que impulsionou o surgimento do consumidor verde.

\subsubsection{Formas de diferenciação no segmento da moda}

O estudo científico no segmento da moda no Brasil é recente. O primeiro curso superior de moda foi estruturado em 1987, na Faculdade Santa Marcelina, em São Paulo. Pesquisadores que almejassem estudar o campo da moda procuravam desenvolver suas pesquisas em outras faculdades, como na Sociologia da USP, faculdade em que foi defendida a primeira tese de doutorado em moda por Gilda de Mello e Souza, cujo título era "A moda no século XIX" (BONADIO, 2010).

Os primeiros eventos de cunho científico no Brasil no campo da moda começaram a ser realizados no final dos anos 1990 e passaram a ter maior participação de pesquisadores a partir de 2005, com a primeira edição do Colóquio de moda, que em 2012 realizou sua $8^{\text {a }}$ edição.

Logo, para compor a presente sessão buscaram-se estudos científicos que abordassem o conceito de diferenciação no contexto da moda, no entanto, foram encontrados poucos trabalhos. Dentre os estudos analisados, percebeu-se que o produto de moda diferenciado agrega diversos atributos e qualidades intrínsecos, relacionados ao custo da matéria-prima e de fabricação, e extrínsecos, no que tange ao apelo e ao design, que são percebidos pelo 
consumidor e que estão em sintonia direta com seus desejos e expectativa (RYBALOWSKI, 2008).

Kikuchi e Silva (2011) apontam que para oferecer produtos de moda e atender os consumidores exigentes em um mercado cada vez mais competitivo, faz-se necessário que a empresa tenha engajamento na fase de pesquisa e elaboração. Rybalowski (2008) acrescenta que o processo de agregação de valor deve incorporar tecnologia e o aspecto artesanal

Com isso, Rybalowski (2008) entende que o processo de produção de produtos diferenciados no segmento de moda deve seguir as seguintes variáveis: 1) qualificação e habilidades técnicas da mão-de obra; 2) design e estilo capazes de diferenciar o produto - o design deve agregar valor por meio da inovação, pela diferenciação e qualidade que gera ao produto, e 3) acesso à tecnologia compatível com os produtos desenvolvidos.

Por outro lado, outros autores apontam que o segmento deve considerar no processo de desenvolvimento de produto de moda e do seu design, uma série de elementos, tais como: a busca pela sustentabilidade; o impacto ambiental e suas consequências, a inter-relação entre a economia e a globalização cultural (ROCHA et al., 2005; EMERENCIANO, PIRES, 2006). Rocha et al. (2005) sugerem também que o produto de moda deve ser trabalhado em três vertentes: a ergonomia, as tendências e a subjetividade.

De acordo com Kikuchi e Silva (2011) a necessidade de agregar valor, no segmento em estudo, transcende a funcionalidade, a estética e o conforto e, por isso, acreditam que o design, a arte e a sustentabilidade são atributos importantes no processo de diferenciação e desenvolvimento de novos produtos.

Já um estudo realizado por Danskin et al. (2005) sobre a cadeia produtiva têxtil nos EUA apontou que, naquele país, a indústria têxtil e do vestuário, utiliza a estratégia de diferenciação com base no mercado, ou seja, com foco no posicionamento do produto. No entanto, esses autores citam que a diferenciação baseada em inovação, no segmento da moda, também pode ser bem sucedida na medida em que a inovação antecipa desejos futuros dos clientes/mercado.

Zatta et al. (2011) citam que o agente ofertante, em todos os segmentos, deve ter consciência 
de que oferecer um produto com qualidade e preço adequado ao seu público alvo, não são os únicos atributos para conquistar e manter seus clientes. Logo, esses autores citam fatores que diferenciam produtos de moda, como: (1) inovação, no sentido de permitir a melhoria dos processos ao aumentar a produtividade e agregar valor aos produtos; (2) o design, não só do produto, mas a forma como este é apresentado ao público, abarcando desde a logomarca, a embalagem, o material de comunicação e a sinalização no ponto de vendas, podendo ser incorporado na cadeia produtiva, e (3) identidade por meio do design único.

Entende-se, de acordo com o apontamento de Zatta et al. (2011), o design além do âmbito do produto, referindo-se à imagem de marca que a empresa busca transmitir ao seu público alvo por meio de todos os pontos de contato do cliente junto à marca. Assim, corroborando com esta colocação, Brïdson e Evans (2004) defendem que os ofertantes de moda devem se diferenciar face à concorrência, por meio do branding - gestão de marca - não só do produto, mas também na experiência oferecida ao consumidor no ponto de vendas.

A partir da ótica dos pesquisadores do segmento da moda, entende-se que o produto no segmento em estudo diferencia-se por meio: da sustentabilidade nos processos e no produto (KIKUCHI, SILVA, 2011; ROCHA et al., 2005; EMERENCIANO, PIRES, 2006); pela inovação, de produto e processos (ZATTA et al., 2011; DANSKIN et al., 2005; RYBALOWSKI, 2008); pela imagem (ZATTA et al., 2011; BRÏDSON, EVANS, 2004), e pelo design, que abrange a qualidade, o estilo, a inovação e os aspectos artesanais do produto (RYBALOWSKI, 2008) e versa ainda, sobre a arte no produto (KIKUCHI, SILVA, 2011) e a sua identidade (ZATTA et al., 2011). Por isso, algumas empresas brasileiras estão buscando implementar estratégias com foco na comercialização de produtos de moda com maior valor agregado e na valorização de suas marcas para transações entre fronteiras (VICENTE, 2009).

\subsubsection{A imagem do país de origem como fonte de vantagem competitiva}

Outra fonte de vantagem competitiva que é explorada na literatura com foco na competição em mercados internacionais é a distinção da oferta por meio da imagem do país de origem (FINESTRALI; GARRIDO, 2010; GIRALDI; TORNAVOI, 2004; 2005).

Giraldi e Tornavoi (2005) apontam, em seu estudo sobre a utilização de informações sobre o 
país de origem em produtos brasileiros como fonte de vantagem competitiva no mercado internacional, que para uma empresa obter uma vantagem competitiva é necessário que essa possua uma característica única que não possa ser copiada ou adquirida pelos seus oponentes. Assim, os autores defendem que o país de origem de um produto apresenta tal característica e, por isso, sugerem que a imagem do Brasil pode vir a ser explorada como forma de diferenciação na oferta de produtos em outros mercados, podendo resultar em uma fonte de vantagem competitiva a partir do momento em que o cliente perceba a superioridade dessa oferta.

Desse modo, Giraldi e Tornavoi (2005) acreditam que a imagem do Brasil pode ser considerada um recurso intangível para uma empresa que busca comercializar entre fronteiras, tornando-se assim, a base para a estruturação de uma estratégia de diferenciação de produtos brasileiros.

De acordo com Giraldi et al. (2011 b) o estudo sobre os efeitos do país de origem tem sido foco de pesquisas acadêmicas há mais de quatro décadas. Em 1965 foi publicado o primeiro artigo acadêmico por Schooler (1965), o qual demonstrou empiricamente que consumidores discriminam produtos que são idênticos em todos os aspectos menos no país de origem, sendo essa informação influenciadora na avaliação sobre um produto.

Para Giraldi e Tornavoi (2005) os estudos publicados desde então têm buscado identificar processos que possam ajudar na interpretação de como o país de origem influencia a avaliação de um produto. Agrawal e Kamakura (1999) complementam ao afirmar que desde o início do estudo da temática, muitos pesquisadores têm se dedicado a compreender e examinar o efeito país de origem sobre a avaliação do consumidor com relação: à qualidade do produto, às crenças sobre os atributos individuais de um produto, à atitude com relação à marca e o comportamento do consumidor em decorrência disso.

No entendimento de Gürhan-Canli e Maheswaran (2000) o efeito país de origem refere-se à forma como o local em que o produto foi manufaturado influencia na avaliação do consumidor com relação ao produto. Esses autores citam que estudos sugerem que o efeito país de origem é utilizado como uma pista na avaliação de novos produtos sob várias condições. Nesee sentido, Kotler e Gertner (2002) apontam que o efeito país de origem se tornou parte do repertório de pistas extrínsecas para avaliação do produto junto ao preço, 
marca embalagem e vendedor. Os últimos autores acrescentam que achados de estudos apontam que os consumidores utilizam o efeito país de origem como indicador de qualidade.

Giraldi e Tornavoi (2005) ponderam que algumas características do consumidor podem influenciar no efeito país de origem, a saber: idade e sexo, educação e conservadorismo, familiaridade com a marca, fluência na língua do país, necessidade de cognição, grau de envolvimento com e cultura, motivação e quantidade de pistas sobre o produto.

Al-Sulati e Baker (1998) em estudo bibliográfico apontam as principais investigações sobre a temática e agrupam os estudos e suas conclusões sobre o tema em cinco categorias: 1) a avaliação do produto; 2) estereotipagem ou estereotipização; 3) os efeitos dos fatores demográficos na percepção do consumidor com relação aos produtos importados; 4) o risco percebido como determinante do efeito país de origem, e 5) o efeito país de origem na avaliação sobre aquisição de serviços.

No entanto, com o número de artigos acadêmicos que passam de 400 estudos publicados em periódicos (USUNIER, 2006), Roth e Diamantopoulos (2009) apontam que, apesar da robustez teórica sobre a temática, o constructo sobre o país de origem ainda mostra-se inconsistente. Ainda de acordo com esses autores, o estudo sobre o efeito do país de origem teve seu foco deslocado da busca pelo entendimento sobre as diferenças na avaliação do produto e as preferências baseadas na noção do país de origem do produto para um constructo complexo que passa a considerar a imagem do país.

Nesse sentido, Giraldi et al. (2011a; 2011b), explicam o deslocamento do foco dos estudos sobre o efeito país de origem ao apontar que esse termo faz referência aos efeitos das informações sobre o país de origem nas atitudes e comportamentos dos consumidores com relação aos produtos. Com isso, considera-se que o país de origem influencia nas avaliações e decisões de compra dos consumidores com relação a produtos (GIRALDI; TORNAVOI, 2004; GIRALDI et al., 2011a; 2011b). Assim sendo, os autores entendem que os efeitos derivados das informações sobre o país de origem são diretamente influenciados pela imagem que o consumidor tem deste país (GIRALDI et al., 2011b).

Para Kotler e Gertner (2002) a imagem de um país é resultado da sua geografia, história, música, arte, proclamações, cidadãos famosos entre outras características nacionais. Giraldi e 
Tornavoi (2005) seguem os apontamentos de Kotler e Gertner (2002) e acrescentam às variáveis que criam a imagem do país: produtos representativos, tradições e panorama econômico e político.

Kotler e Gertner (2002) defendem ainda que a imagem do país pode influenciar as decisões das pessoas com relação à compra, investimento e viagens. Desse modo, tais autores defendem que a imagem do país pode ser entendida como a soma das impressões e crenças que as pessoas têm em relação a lugares e entendem que as imagens representam a simplificação de muitas associações e informações que são conectadas a um lugar. Sendo assim, a imagem de um país é produto da mente que busca processar e escolher informações essenciais dentre diversas informações e dados sobre determinado lugar (KOTLER, GERTNER, 2002).

Corroborando com os apontamentos de Giraldi e Tornavoi (2005) e de Kotler e Gertner (2002), Wang, Barnes e Ahn (2011) citam que a imagem do país refere-se à representação mental de um país e seu povo, abarcando as crenças cognitivas com relação aos estágios de desenvolvimento econômico e tecnológico do país, assim como as avaliações afetivas do sistema social e político.

Nesse sentido, Giraldi e Tornavoi (2005) apontam que as inferências feitas pelos consumidores com relação a um país estão ligadas às crenças que os consumidores possuem acerca do país, sendo essas crenças formadas a partir de associações passadas. Os autores apontam ainda que tais referências se alicerçam nos sinais e símbolos relacionados com o país, e assim, a imagem formada do país se dá por meio da percepção total que o consumidor possui com relação a um país, ao processar as informações provenientes de várias fontes no decorrer do tempo.

Com isso, Giraldi et al. (2011b) entendem que as conotações simbólicas e emocionais do país de origem o transformam em um atributo de imagem. Logo, a imagem de um país interfere nas avaliações e decisões de compra que os consumidores fazem no tocante aos produtos fabricados neste país, (GIRALDI, TORNAVOI, 2004; 2005; GIRALDI et al., 2011a). Nesse sentido, os estudos que centram-se no país de origem passaram a buscar mensurar a imagem do país, dando origem ao estudo sobre a imagem do país de origem (ROTH, DIAMANTOPOULOS, 2009). 
Roth e Diamantopoulos (2009) citam, porém, que não há consenso na literatura sobre o constructo da imagem do país de origem. Desse modo, sem análises sistemáticas para operacionalizar o fenômeno e sem escalas que mensurem a imagem do país de origem, os pesquisadores não encontram apoio em nenhum guia que os ajude a operacionalizar o constructo e assim, muitos autores misturam os conceitos de país de origem e o de imagem do produto manufaturado naquele país (GIRALDI et al., 2011b).

De acordo com Giraldi et al. (2011b), os estudos sobre a imagem do país de origem que tenham o Brasil como objeto de pesquisa ainda estão no estágio inicial. Por isso, esses autores realizaram um estudo qualitativo exploratório e perguntaram à sua amostra (estudantes holandeses) que dissessem algumas palavras que vinham à mente deles quando pensavam sobre o Brasil.

As respostas foram agrupadas em cinco categorias: população, política, natureza, esportes e economia. Os achados apontam que a imagem quanto à população brasileira é concebida por meio de três subcategorias: mulheres (sensualidade e beleza da mulher brasileira); receptividade (afetividade e hospitalidade); cultura (comida e carnaval). Quanto à política, os respondentes apontaram corrupção, desigualdade social e violência como elementos que compõem a imagem do país neste prisma. Com relação à categoria Natureza, foram mencionados as praias, o clima e as belezas naturais. Quanto à categoria que se referia aos esportes, citou-se ídolos (como Airton Senna) e o futebol. Por fim, quanto às palavras que remetiam à economia, destacou-se a ascensão e produtos (GIRALDI et al., 2011b).

Para fins deste estudo, será considerado o conceito de imagem do país de origem citado por Kotler e Gertner (2002) de que a imagem de um país é resultado da sua geografia, história, música, arte, proclamações, cidadãos famosos entre outras características nacionais, assim como, os apontamentos de Giraldi et al. (2011b), de que as conotações simbólicas e emocionais do país de origem o transformam em um atributo de imagem e interfere nas avaliações e decisões de compra que os consumidores fazem no tocante aos produtos fabricados naquele país (GIRALDI, TORNAVOI, 2004; 2005; GIRALDI et al., 2011a).

A partir da pesquisa bibliográfica centrada nas fontes de vantagem competitiva observou-se que existem fontes de vantagens competitivas internas e externas à organização. As vantagens competitivas de origem interna estão relacionadas aos processos organizacionais, ou seja, são 
obtidas quando a empresa implementa estratégias apoiadas na: 1) visão baseada recursos, ou na 2) liderança de custos, ou 3) com foco em processos internos. Logo, essas vantagens competitivas se dão por meio da utilização de: a) processos internos que permitem a liderança de custos; b) recursos e competências da empresa que geram valor para a empresa e que são difíceis de serem imitados pelos concorrentes; c) pela diferenciação baseada em funcionários e, d) por meio da diferenciação baseada no canal de distribuição.

Quadro 1 - Fontes de Vantagem Competitiva

\begin{tabular}{|c|c|c|c|}
\hline $\begin{array}{l}\text { Origem da } \\
\text { Vantagem } \\
\text { Competitiva } \\
\end{array}$ & $\begin{array}{l}\text { Estratégia } \\
\text { Competitiva } \\
\text { baseada em }\end{array}$ & $\begin{array}{c}\text { Natureza da vantagem } \\
\text { Competitiva }\end{array}$ & Autor \\
\hline \multirow{4}{*}{ Interna } & Liderança de Custo & $\begin{array}{c}\text { Processo interno que permite a } \\
\text { liderança de custos }\end{array}$ & Porter (1989) \\
\hline & \multirow[t]{2}{*}{$\begin{array}{l}\text { Visão baseada em } \\
\text { recursos }\end{array}$} & $\begin{array}{l}\text { Recursos e competências da } \\
\text { empresa que geram valor a } \\
\text { empresa e que são difíceis de } \\
\text { serem imitados pelos concorrentes }\end{array}$ & $\begin{array}{c}\text { Barney (1991); } \\
\text { Day e Wensley (1998) }\end{array}$ \\
\hline & & $\begin{array}{c}\text { Diferenciação baseada em } \\
\text { funcionários }\end{array}$ & Kotler e Keller (2006) \\
\hline & Processos internos & $\begin{array}{c}\text { Diferenciação baseada no canal } \\
\text { de distribuição }\end{array}$ & Kotler e Keller (2006) \\
\hline \multirow{8}{*}{ Externa } & \multirow{8}{*}{ Diferenciação } & Por Produto & Kotler e Keller (2006) \\
\hline & & Por imagem & $\begin{array}{c}\text { Mintzberg (2006); Kotler e } \\
\text { Keller (2006); } \\
\text { Zatta et al. }(2011) ; \\
\text { Brïdson e Evans (2004). }\end{array}$ \\
\hline & & Por suporte ou serviços & $\begin{array}{c}\text { Mintzberg (2006); Kotler e } \\
\text { Keller (2006) }\end{array}$ \\
\hline & & Por design & $\begin{array}{l}\text { Mintzberg (2006); Kotler e } \\
\text { Keller (2006); } \\
\text { Kikuchi e Silva (2011). }\end{array}$ \\
\hline & & Por qualidade & Mintzberg(2006) \\
\hline & & Por Sustentabilidade & $\begin{array}{c}\text { Orsato (2006); } \\
\text { King e Lenox (2001); } \\
\text { Elkinton (1994); } \\
\text { Kikuchi e Silva (2011); } \\
\text { Rocha et al. }(2005) ; \\
\text { Emerenciano e Pires } \\
\text { (2006) }\end{array}$ \\
\hline & & Por Inovação & $\begin{array}{l}\text { When-Cheng et al. (2011); } \\
\text { Danskin } \text { et al. (2005) } \\
\text { Zatta et al. (2011); } \\
\text { Rybalowski (2008). }\end{array}$ \\
\hline & & Pela imagem do país de origem & $\begin{array}{c}\text { Finestrali e Lapuente } \\
\text { (2010); Giraldi e Tornavoi } \\
\text { (2005) }\end{array}$ \\
\hline
\end{tabular}

Fonte: Elaborado pela autora

Já a vantagem competitiva com origem externa, tem como base os atributos de produtos e serviços que geram valor ao comprador. Tal vantagem competitiva pode ser obtidas por meio da implementação de estratégias baseadas na diferenciação, podendo a distinção da oferta ser: 
a) por produto; b) pela imagem; c) por suporte ou serviços; d) pela qualidade; e) pela sustentabilidade; f) pela inovação, e g) pela imagem do país de origem. O quadro 1 agrupa as principais fontes de vantagem competitiva encontradas na fundamentação teórica.

No presente estudo, considerou-se somente a fonte de vantagem competitiva externa à organização, ou seja, o estudo embasa-se nas formas de diferenciação, mais especificamente na distinção por meio da imagem do país de origem, uma vez que a pesquisa se dá no contexto da moda no mercado internacional e buscou compreender quais atributos da imagem do país de origem são reconhecidos e valorizados no produto de moda pelos agentes de mercado.

\subsection{Contextualização do segmento da moda}

Diante da atual configuração de mercado, nota-se que as empresas brasileiras também estão buscando seu espaço e, para tanto, passaram por reestruturações logo após a abertura comercial em 1990. Processos esses que ganharam força com a estabilização da moeda local e que estão favorecendo as condições de competição das empresas brasileiras nas transações internacionais.

O setor da moda, também teve que passar por diversas reconfigurações desde a intensificação do movimento de integração de mercados. Segundo Costa e Rocha (2009), o processo de liberalização do comércio na cadeia têxtil e de confecção teve como consequência o acirramento da concorrência internacional, demandando que as empresas redefinissem suas estratégias competitivas.

De acordo com o IEMI (2011) a aceleração do processo de integração de mercados iniciado na década de 80 , teve como desdobramento a emigração de significativa parcela da produção de artigos têxteis e confeccionados dos EUA, da União Europeia e do Japão para países emergentes da Ásia e, ultimamente, para o Leste Europeu, Norte da África e Caribe, modificando substancialmente o mapa da produção de têxteis no mundo.

Tais apontamentos corroboram com os de Hansen (2004), ao citar que a moda contemporânea está sendo rapidamente criada e em considerável quantidade em países da América Latina, 
África e Ásia e, com o desenvolvimento de produtos a partir desses continentes, a moda está redefinindo seus processos e redefinindo o consumo, assim como impulsionando mudanças de estilo advindas de e para diversas partes do globo.

\subsubsection{Panorama do Mercado da Moda}

As indústrias têxteis e de confecções representam duas dentre as atividades industriais mais antigas da humanidade (FEGHALI, 2004). Como se verá com maior detalhamento na parte final desta sessão (2.3.1.1 A Moda Brasileira e a Brasilidade na Moda), a indústria da moda no Brasil começou a ser estruturada a partir da década de 20 e desde então desempenha papel importante na economia e sociedade brasileira.

Atualmente, de acordo com a opinião de Rech (2008), a cadeia produtiva de moda, passa por um período de grandes mudanças em função do processo de integração de mercados e a abertura da econômia. Nesse sentido, para Braga (2008), a partir da década de 1990, a indústria da moda no Brasil participou de um processo de evolução qualitativa de enormes proporções, processo esse que contemplou desde a modernização do parque industrial ao aperfeiçoamento tecnológico. No entanto, Rech (2008) pondera que mesmo vencida a crise dos anos 90, a cadeia produtiva da moda brasileira está inserida em um mercado bastante competitivo.

Dados do IEMI (2011) indicam que o Brasil ocupa $4^{\mathrm{a}}$ posição no ranking mundial de produtores de vestuário e o $5^{\circ}$ lugar dentre os maiores produtores de manufaturas têxteis. A China (Hong Kong) se posiciona como maior representante na manufatura mundial de têxteis e vestuário, com 49\% (IEMI, 2011). Nota-se também que mesmo com a reconfiguração da manufatura global de têxteis, os EUA ainda produzem vestuário, porém sua produção representa somente 5\% do seu consumo interno (IEMI, 2011). A Índia (7\%) e o Paquistão $(3,8 \%)$ também figuram entre os primeiros 4 países com maior participação na produção mundial de vestuário (IEMI, 2011). Em 2009, a produção de artigos de vestuário no Brasil atingiu 40,3 milhões de toneladas (IEMI, 2011).

Entre 1990 e 2009 a produção mundial têxtil cresceu 74\%, ao passo que, no mesmo período, a taxa do comércio internacional de têxteis e vestuário cresceu mais que o dobro, na ordem de 
188\%, atingindo US\$ 526,7 bilhões (IEMI, 2011). Considerando-se somente o vestuário, a taxa de crescimento chegou a 192\% acumulados no período (IEMI, 2011). Neste contexto, China e Hong Kong juntos representam 36\% das exportações mundiais de produtos têxteis e do vestuário, mas a Alemanha e a Itália continuam presentes e permanecem como grandes exportadoras (IEMI, 2011).

O Brasil, apesar de figurar como um dos grandes produtores e também um dos maiores consumidores mundiais, tem baixa representatividade no comércio internacional (IEMI, 2011; BNDES in COSTA; ROCHA, 2009), ocupando a 24a posição dentre os maiores exportadores têxteis e a $75^{\mathrm{a}}$ posição dentre os maiores exportadores de vestuário, com isso, o país caracteriza-se pelo perfil produtor-consumidor, ou seja, a indústria têxtil continua orientada para o mercado interno ao produzir para consumo nacional, destinando pequena parcela à exportação (IEMI, 2011; COSTA, ROCHA, 2009; RECH, 2008).

No ano de 2010, o comércio externo brasileiro também foi influenciado pelas taxas cambiais que, com a excessiva valorização do Real, prejudicou as exportações e ainda incentivou a importação; ambiente competitivo que teve sua rivalidade reforçada com a presença dos países asiáticos, que atualmente dominam o comércio internacional de artigos têxteis e do vestuário (IEMI, 2011; COSTA; ROCHA, 2009).

De acordo com o IEMI (2011) os dez países que mais importam moda no mundo são: Estados Unidos, Alemanha, Japão, Reino Unido, França, Hong Kong, Itália, Espanha e Holanda. Dados que corroboram com os apontamentos do BNDES (in COSTA, ROCHA; 2009) de que em 2006 os países desenvolvidos representavam 80\% do consumo total no segmento do vestuário. No entanto, os principais destinos dos produtos de vestuário Brasileiro são: Paraguai, Argentina, EUA, Chile, Uruguai, Bolívia, Japão, Portugal, Angola e França (IEMI, 2011), ou seja, o Brasil exporta somente para três dos países mais receptivos à exportação.

Segundo opinião de Costa e Rocha (2009), assim como o IEMI (2011), o segmento têxtil mostra-se relevante para a economia brasileira ao participar com 5,5\% da receita líquida da indústria de transformação em 2010 e, ainda, representar 16,4\% do emprego total da indústria de transformação nacional (IEMI, 2011). Segundo a Associação Brasileira da Indústria Têxtil e de Confecção (ABIT, 2012), o setor é o segundo maior empregador da indústria em transformação, contando com cerca de 1,7 milhões de trabalhadores diretos, ocupando 
colocações nas mais de 30 mil empresas que compõem o setor, as quais conseguiram faturar US\$ 60 bilhões em 2010 (ABIT, 2012).

Apesar dos obstáculos e barreiras enfrentadas pelo setor, como elevada carga tributária, dos juros, o câmbio, o custo dos encargos sociais e o crescimento dos importados (FILHO, 2011 in IEMI, 2011, p. 10; ZATTA et al., 2011), a necessidade de reforma em portos, aeroportos, investimentos na matriz energética e na educação (BRUNO et al., 2009), dificuldades de acesso a financiamentos, problemas logísticos e a infraestrutura precária (COSTA; ROCHA, 2009), e o mercado internacional que é dominado há muitos anos por grupos Italianos, Franceses, Ingleses e recentemente Americanos (MANETTI, 2006) a indústria brasileira de moda apresenta grande potencial competitivo (FILHO, 2011 in IEMI, 2011, p. 10; ZATTA et al., 2011). Tal setor, ao longo dos 17 anos da implantação do plano real, é o que menos inflacionou ao longo deste período (FILHO, 2011 in IEMI, 2011, p. 10). Assim, o setor conseguiu captar reservas do BNDES (COSTA; ROCHA, 2009) que emprestou US\$1,93 bilhão para os elos da indústria têxtil e de confecção entre 2000 e 2008.

De acordo com Costa e Rocha (2009), a atual conjuntura do mercado têxtil e confeccionados, em que os países asiáticos apresentam crescimento exponencial, desestabilizou os demais países produtores dessa indústria e acirrou a competição global. Diante desse contexto, esses autores apontam que se tornou fundamental para a sobrevivência das empresas dessa indústria, desenvolver estratégias competitivas diferenciadas e com base na utilização da inovação tecnológica como instrumento indispensável para inserção no mercado mundial.

Nesse sentido, Bruno et al. (2009) destacam que o Brasil tem ativos escassos que a indústria têxtil precisa aprender a utilizar, como: a diversidade cultural e técnica de processos artesanais; a estrutura fabril e a experiência técnica e comercial desta indústria; os novos talentos que estão sendo reconhecidos no mundo da moda pelo design inovador; assim como a imagem positiva de símbolos nacionais.

No entanto, Costa e Rocha (2009) evidenciam que a estratégia competitiva utilizada pelas empresas brasileiras consiste predominantemente em seguir as tendências de moda internacionais, buscando nichos de mercado para oferecer produtos diferenciados (com marca e designers reconhecidos). Porém, esses autores destacam o trabalho de empresas que desenvolvem suas estratégias com base no fortalecimento da imagem do Brasil como 
característica de qualidade de produto, de estilo próprio e respeito socioambiental.

A despeito da conjuntura apresentada não mostrar-se favorável para o setor da moda nacional, os designers brasileiros, ao seguir a estratégia de diferenciação - parte deles por meio da imagem do Brasil, conforme apontado por Costa e Rocha (2009) - começaram a ganhar espaço no mercado internacional. Nota-se tal movimento por meio da análise dos números da exportação por parte dos designers que em 2003 era de US\$ 3 milhões e passou para US\$ 18,3 milhões em 2011 (ABEST, 2012).

\subsubsection{Dinâmica do Setor}

No âmbito global a indústria da moda está à frente das indústrias emergentes (ROCHA et al., 2005) e é grande e competitiva (GOLDSMITH, FLYNN, CLARK, 2012; RECH, 2008) . De acordo com a opinião de Rocha et al. (2005), o fato dessa indústria se estruturar por meio da promoção de seus produtos utilizando a previsão de tendências e enfatizando o curto ciclo de vida dos produtos permite que esse segmento continue crescendo e se desenvolvendo dentre as demais indústrias.

Assim, o mercado da moda é caracterizado pela frequente mudança de estilos fazendo com o que o consumidor também mude seus gostos e, por isso, torna um desafio o entendimento das razões pelas quais o consumidor compra e segue tal dinâmica (GOLDSMITH et al., 2012).

Law et al. (2004) denominam esse ciclo rápido de fashion change, ou mudança de moda, que pode ser entendido como a obsolescência planejada promovida por varejistas de moda que buscam motivar os consumidores a comprar novas roupas constantemente. Tais autores complementam, citando que a mudança de moda é um processo composto por vários estágios, que inclui as alterações nas roupas e nos estilos de aparência, a aceitação, a difusão e o declínio. Nesse sentido, Rocha et al. (2005) apontam que as empresas que participam desse segmento devem responder com mais velocidade às rápidas mudanças de mercado para atender esse consumidor.

Conforme cita D’Almeida (2008), os agentes que operam na cadeia produtiva do mercado de moda desenvolvem suas atividades em função da contemplação de uma agenda produtiva que 
deve responder à sazonalidade para o consequente consumo. Nesse sentido, esse autor reforça a importância do papel das tendências nessa indústria, como impulsionador do consumo.

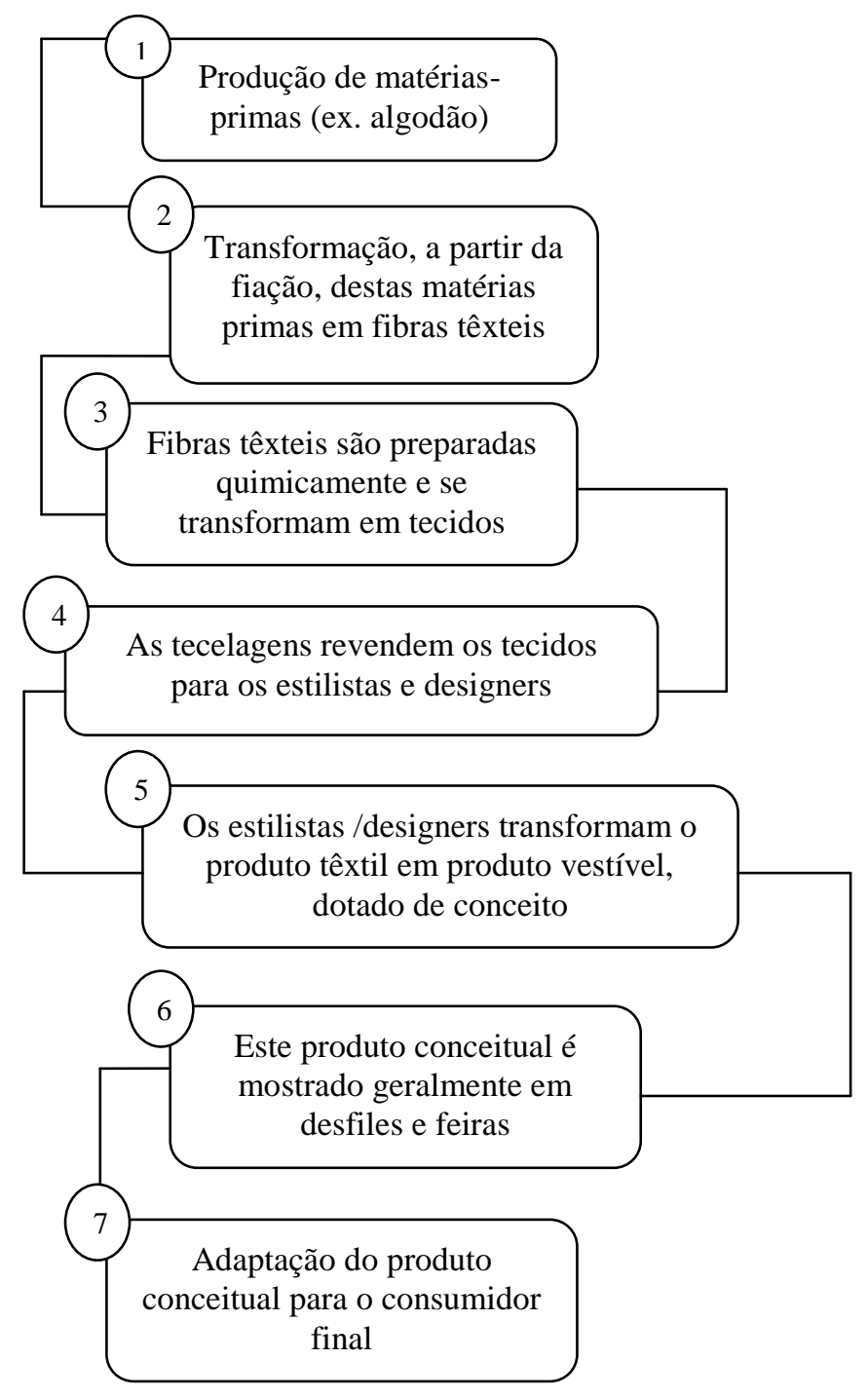

\section{Ilustração 5 - Regulação do mercado de moda} Fonte: D’ALMEIDA; 2008, p.88.

Seguindo a mesma linha de raciocínio, a opinião de Feghali (2004) é a de que a indústria da moda opera em ciclos semestrais de tendências e cita que as cores, estilos, texturas variam rapidamente, assim, para essa autora, faz-se necessário estar sempre em sintonia com tais mudanças. Logo, acontecem no mínimo dois ciclos de moda por ano, sendo que um deles foca-se na coleção de inverno e o outro tem como objetivo criar produtos para o verão. Por isso, Braga (2005; p. 22) acredita que a moda é "autodestruidora [...] vivendo e se beneficiando da sua própria morte". D’Almeida (2008) esquematiza a regulação do mercado de moda e como cada ciclo acontece ao longo da cadeia produtiva de moda por meio da 
ilustração 5.

\subsubsection{Agentes do Setor}

A indústria da moda, assim como qualquer outra indústria, é composta por agentes ofertantes e agentes demandantes. Os primeiros abarcam os produtores e, neste estudo, são representados pelas marcas, pelos designers, assim como pelas entidades de apoio ao segmento. Já os agentes de demanda, referem-se aos compradores, que podem ser compradores industriais (B2B) ou consumidores finais.

Os agentes demandantes são representados pelos compradores internacionais, podendo ser intermediários ou consumidores finais. Os primeiros visam obtenção de ganho por meio da venda de produtos de moda (roupas) comprado anteriormente, sendo esse mercado composto por empresas que adquirem produtos com a finalidade de revendê-los em seus mercados de origem (LAMBIN; 2000; CAMPOMAR; 2012). Com isso, o B2B internacional da moda é representado por empresas compradoras de produtos brasileiros que se dispõem a vir ao Brasil participar de eventos de moda (Fashion Week) para comprar produtos de moda e distribuir em seus mercados de atuação para os consumidores finais, os quais, por sua vez, adquirem produtos de moda brasileiros para uso próprio (CAMPOMAR; 2012).

Entre o elo ofertante e o demandante, no ambito internacional, existem as tradings companies, que são sociedades comerciais internacionais que têm escritórios em diversos países e que controlam importantes canais comerciais em certas regiões, podendo representar empresas que não buscam se envolver diretamente com o mercado internacional (LAMBIN, 2000).

Do lado ofertante, observou-se que a partir do final da década de 1990, o mercado e o governo começaram a se organizar para dar suporte ao crescimento e incentivar o setor a obter melhores resultados, constituindo Agências e Associações como a Apex (Agência de Promoção de Exportação), a Abest (Associação Brasileira de estilistas), o projeto TexBrail e a Abit (Associação Brasileira da Indústria Têxtil e de Confecção), a última desenvolve atividades desde o final dos anos 1950.

A Apex Brasil (Agência de Promoção de Exportação), tem por objetivo implementar a 
política de promoção comercial das exportações brasileiras, exercendo importante papel na promoção da moda brasileira no exterior, por meio de cerca de dez projetos setoriais integrados. A agência não só atende à complexidade da economia nacional, como também, ao alto grau de sofisticação da comercialização de bens e serviços nos mercados globalizados (APEX, 2012).

A Abit, Associação Brasileira da Indústria Têxtil e de Confecção, é a mais antiga associação do setor e foi fundada em 1957, representando uma das mais importantes entidades dentre os setores econômicos do País (ABIT, 2012). Em 2000 a Apex junto a Abit criaram o TexBrasil, Programa de Exportação da Indústria da Moda Brasileira, cujo objetivo é dar suporte às empresas deste setor interessadas na inserção de seus produtos em outros mercados.

Atualmente o TexBrasil conta com a participação de cerca de 400 empresas, e o projeto, ao longo dos últimos dez anos, alcançou a o número de US\$ 330 milhões em negociações das marcas brasileiras no exterior (APEX, 2011 in IEMI, 2011).

Em março de 2012, o convênio entre Apex e Abit foi renovado, com uma previsão de investimento de $\mathrm{R} \$ 17,5$ milhões ao longo dos primeiros 12 meses. Um dos projetos, fruto do convênio entre Associação e Agência, é o projeto comprador, o qual identifica compradores internacionais em potencial e patrocina a vinda dos mesmos ao Brasil. Desde o início do projeto, o TexBrasil trouxe aproximadamente 960 compradores para participar de 147 eventos do setor, resultando em benefício para mais de 3000 empresas que realizam negócios em torno de US\$ 61 milhões (TEXBRASIL, 2012). O Texbrasil estimula também, a vinda ao Brasil de jornalistas e formadores de opinião estrangeiros para os maiores eventos de moda nacional. Em 2010 o programa proporcionou a vinda de 70 jornalistas internacionais de 14 países alvo (APEX, 2011 in IEMI, 2011).

O setor têxtil conta ainda com a Abest, Associação Brasileira de estilistas, que nasceu em 2003 visando fortalecer e promover a indústria de moda nacional focada nos seguintes pilares: qualidade, design e identidade. Outro objetivo da associação é desenvolver marcas de alcance internacional, bem como contribuir para o crescimento de todos os segmentos vinculados à moda brasileira. Para tanto a Abest auxilia seus associados - que eram 5 em 2003 e hoje são 55 grifes - no desenvolvimento da moda nacional em mercados externos, por meio de ações, desfiles, showroom, feiras, encontros, parcerias, estudos entre outros incentivos (ABEST, 
2012).

A Abest em parceria com a Apex criou o projeto $+\mathrm{B}$, cujo objetivo é transformar o país em repertório criativo. Para materializar a pesquisa o projeto criou um caderno de inspiração para desenvolvimento de coleções bilíngue que tem edições anuais desde 2008 (ABEST, 2012).

Além das entidades anteriormente mencionadas, o setor conta com os produtores, os quais são representados pelas marcas e designerss (empresas) que produzem suas coleções de modo a ofertar produtos com valor agregado, ou seja, com diferencial. Neste estudo, serão considerados nesse grupo de empresários, as marcas e estilistas que desenvolvem suas atividades junto às instituições Apex, Abit e Abest. As marcas associadas à Abest estão reunidas no quadro 2.

Quadro 2 - Designers e Marcas de moda que estão se internacionalizando

\begin{tabular}{|l|l|l|}
\hline Adriana Praça & Giovanna Parizzi & Mixed \\
Água de Coco & Giuliana Romanno & Osklen \\
Akihito Hira & Gloria Coelho & Patachou \\
AlexandreHerchcovitch & Huis Clos & Pedro Lourenço \\
Amir Slama & Iodice & Poko Pano \\
Ank Swimwear & Isabela Capeto & Reserva \\
Anunciação & Jo de Mer & Ronaldo Fraga \\
Brigitte & Lenny & Saad \\
Carina Duek & Lilly Sarti & Salinas \\
Carlos Miele & Lolitta & SannMarcuccy \\
Carlos Miele Jeans & Luxe Za.Za & Serpui Marie \\
Cavage & Mara Mac & Skinbiquini \\
Cavalera & Marcelo Quadros & Sol de Janeiro \\
Cecilia Echenique & Maria Bonita & Thais Gusmão \\
Cecilia Prado & Maria Bonita Extra & Triya \\
Cia.Marítima & Martha Medeiros & Uma \\
Clube Bossa & Mauricio Medeiros & Vitorino Campos \\
Cris Barros & Miss Schuster & Vix Swimwear \\
Dalai Beachwear & Missinclof & Walter Rodrigues \\
Fernanda Yamamoto & & \\
\hline
\end{tabular}

Fonte: ABEST, 2012.

A indústria da moda conta ainda com outros agentes (PIRES, 2007). Em 2009, o Ministério do Desenvolvimento, Indústria e Comércio Exterior (MDIC), criou o Sistema de Moda Brasil que funciona como um instrumento de articulação entre as cadeias produtivas relacionadas à moda, contemplando têxtil e de confecções; gemas, joias e afins; e couro, calçados e artefatos (MDIC, 2009). Para tanto, o grupo tem como objetivos: o desenvolvimento de projetos que beneficiem a indústria da moda; assim como deve compartilhar e integrar informações e experiências; buscar soluções em conjunto para problemas que se mostrem semelhantes; 
incentivar o associativismo e o cooperativismo, bem como desenvolver a inteligência competitiva (MDIC, 2009).

O Sistema Moda Brasil - SMB - integra os ministérios da Cultura, Ciência e Tecnologia e Relações Exteriores, Agência Brasileira de Desenvolvimento Industrial (ABDI), Agência Brasileira de Promoção de Exportação e Investimento (Apex-Brasil) e Banco Nacional de Desenvolvimento Econômico e Social (BNDES). Assim como, tem representantes da iniciativa privada das seguintes entidades: Serviço Nacional de Aprendizagem Industrial (Senai), Serviço Nacional de Aprendizagem Comercial (Senac), Serviço Brasileiro de Apoio às Micro e Pequenas Empresas (Sebrae), Associação Brasileira de Estilistas (Abest), Associação Brasileira da Indústria Têxtil e de Confecção (Abit), Associação Brasileira de Produtores de Fibras Artificiais e Sintéticas (Abrafas), Associação Brasileira das Indústrias de Calçados (Abicalçados), Associação Brasileira de Empresas de Componentes para Couro, Calçados e Artefatos (Assintecal), Centro das Indústrias de Curtume do Brasil (CICB), Instituto da Moda (Inmod) e Instituto Brasileiro de Gemas e Metais Preciosos (IBGM) (MDIC, 2009).

Como esta pesquisa visa estudar a indústria da moda de produtos com valor agregado, os agentes de mercado nos quais o estudo se centrará são: profissionais que atuam junto às agências e associações do setor que apoiam a inserção do produto de moda brasileiro no mercado externo (Apex, Abit e Abest) e os compradores internacionais (B2B).

Cabe destacar ainda que, diante do papel representado pela indústria do moda na economia nacional e do destaque que a moda Brasileira tem ganhado no mercado externo, o Ministério da Cultura organizou o I seminário de Cultura da Moda visando estabelecer uma política para valorizar a criação, a inovação e a experimentação da moda nacional, com intuito de que os valores culturais do país sejam agregados aos produtos (AFONSO, 2010). Nesse sentido, a moda nacional, ao ser compreendida como linguagem artística, passou a ser foco de financiamento público do Ministério da Cultura (AFONSO, 2010). 


\subsubsection{O Consumidor de Moda}

A competitividade e as tranformações no mercado também refletiram no comportamento do consumidor no segmento em estudo. De acordo com a opinião de Frings (2001) no passado a maioria das pessoas comprava roupas novas somente quando precisava, pois não tinha poder aquisitivo para comprar mais do que o básico. Ainda segundo Frings (2001), atualmente, grande parte da população tem uma renda que permite comprar roupas porque deseja ou gosta delas. Além disso, D’Almeida (2008) aponta outro aspecto considerado pelo consumidor de moda quando esse realiza suas compras, o de que a moda, por meio do vestuário, calçados e acessórios, é responsável por uma grande diversidade de possibilidades que articulam estilos nas dimensões individual e coletiva em busca da inserção nos grupos sociais.

Nesse sentido, o vestir e a maneira como indivíduo o faz, é em primeiro lugar - no entendimento de Braga (2004) e Lage (2011) - uma forma de proteção física que, na opinião destes mesmos autores e de Durand (1988) expressa o cuidado que o indivíduo tem com sua estética, imagem e preservação da sua identidade. Armoni (2007) e Konig (1969) acreditam que o traje apresenta ainda funções como a comunicação não verbal que indica o posicionamento do indivíduo na sociedade (DURAND, 1988; ARMONI, 2007; LIPOVETSKY, 2009; CAVALHEIRO, 2001; FREYRE, 2009), seu estado de espírito (DURAND, 1988; LAGE, 2011) e caracteriza o modo como esse se relaciona com o ambiente em que está inserido (NACIF, 2007; DURAND, 1988). Portanto, de acordo com Lipovetsky (2009), Armoni (2007) e Rech (2002) a forma como o indivíduo se veste, diz respeito a múltiplas dimensões de sua história, versando sobre fatores da vida social, individual, cultural e estética do mesmo, e por isso, o indivíduo, ao comprar seu vestuário acaba por reforçar tais características.

Seguindo esse raciocínio, Feghali (2008) e Frings (2001) citam que as motivações de compra de produtos de moda são emocionais e racionais, e variam de consumidor para consumidor. $\mathrm{Na}$ opinião desses autores, as principais motivações são: para estar na moda; para se sentir atraente; para impressionar aos outros; para ser aceito no grupo e, para suprir uma necessidade emocional.

De acordo com pesquisa realizada por Goldsmith et al. (2012) o consumidor de moda realiza suas compras pautado por três principais motivações: por materialismo (preocupação em 
adquirir bens materiais, tornando tal atividade uma das mais importantes da vida das pessoas), engajamento com a marca para criar seu próprio conceito (quando o individuo se sente satisfeito em comprar bens materiais de uma marca espefícica, com a qual ele se identifica, por isso a marca expressa alguns elementos importantes do indivíduo) e o consumo por status (a compra e exibição de certos produtos como uma forma pela qual o indivíduo se esforça para mostrar seu status social).

Frings (2001) aponta que no setor de moda, os padrões de compra também mudam constantemente. Para determinar a aceitação do produto nesse setor, o autor aponta para a necessidade de se considerar os critérios de escolha utilizados pelos consumidores, que são: percepção de valor; tendências de moda; glamour e feminilidade (para as mulheres); conforto; funcionalidade; múltiplo uso do vestuário e estilo.

Shim e Bickle (1994) realizaram uma pesquisa e identificaram nove fatores que descrevem os benefícios que as consumidoras esperam ao comprar roupas: auto-melhoria; status social/prestígio; feminilidade; imagem de moda; conforto/funcionalidade; identificação; compensação de falhas estéticas; individualidade e look maduro ou sofisticado.

Nesse sentido, Feghali (2008) e Frings (2001) citam que ao comprar produtos de moda, o consumidor considera aspectos de ordem prática como preço, caimento, adequação, marca, performance, qualidade, conveniência e confecção. Feghali (2008), no entanto, pondera que existem outros elementos no vestuário que repelem ou atraem a atenção do consumidor além das considerações habituais apontadas anteriormente, destacando-se os elementos de atração mais visíveis que são: as cores, a textura e o estilo.

Na opinião de Feghali (2008) a cor é o primeiro aspecto da peça que atrai a atenção do consumidor, segundo a autora, as pessoas reagem de uma forma muito pessoal à cor, representando um fator fundamental de rejeição ou agrado. A textura do tecido também se mostra importante, pois o tato está intimamente ligado à parte emocional do consumidor. Por fim, o estilo é definido principalmente pela utilização dos seguintes elementos: a linha, a silhueta e os detalhes (FEGHALI, 2008).

A autora ainda acrescenta que o comportamento de compra da mulher difere do comportamento do homem diante de produtos de moda. A mulher não compra moda de forma 
racional ou lógica, mas sim afetivo-emotiva (FEGHALI, 2008).

Por fim, Rybalowski (2008) opina que o consumidor contemporâneo passou a ter noção de que pode criar sua expressão pessoal e própria imagem por meio do modo de se vestir. Portanto, atitude e desejo de diferenciação, segundo a autora, passam a ser reconhecidos como expressão da atualidade.

Para efeitos deste estudo, com base nos apontamentos apresentados, assume-se que o consumidor de moda é influenciado por aspectos diferenciadores da oferta e busca, em produtos de moda, benefícios que transcendem elementos físicos do produto. Nesse sentido, acredita-se que a diferenciação da oferta e da proposta da marca mostram-se atributos fundamentais para cativar a relação de troca com tais clientes.

\subsubsection{O movimento de internacionalização no segmento do moda}

Conforme discorrido anteriormente, com a abertura do mercado no início da década de 1990, as empresas de moda brasileiras passaram a concorrer com marcas internacionais, fazendo com que os designers buscassem reposicionar suas marcas (MESSIAS, 2009 IEMI, 2011; COSTA; ROCHA, 2009) para não perder suas posições no mercado nacional e também para aprender a competir com as empresas estrangeiras, uma vez que as marcas brasileiras passaram a ter oportunidade de buscar mercado em outros países.

Com isso, Secani e Jorge (2005) acreditam que a entrada de produtos nacionais em outros mercados permitiu que o Brasil promovesse o produto com características nacionais e ainda afirmar tais características para o seu próprio povo. Logo, uma dentre as alternativas utilizadas por muitos designers para demarcar suas posições no mercado, encontrou apoio na transposição de referências da cultura brasileira para suas coleções (MESSIAS, 2009).

Desde então, a moda nacional tem crescido e passa por um momento de profissionalização (ABEST, 2012). De acordo com a Abest (2012) os designers brasileiros têm se destacado em mídias internacionais e ganham cada vez mais importância no contexto internacional. Em 2003 os estilistas exportaram US\$ 3 milhões, número este que, em 2006, passou para US\$ 12 milhões e em 2011 atingiu US\$ 18,3 milhões, com a distribuição de produtos para 66 países 
(ABEST, 2012).

Moore, Fernie e Burt (2000) apontam, porém que uma empresa de moda internacionalizada deve: (1) ter perfil internacional na indústria de moda, por meio da participação em eventos lançadores de moda que acontecem duas vezes por ano em capitais da moda, como Paris, Londres, Milão e Nova Iorque; (2) ter estabelecido seu negócio no segmento da moda por, pelo menos, dois anos; (3) comercializar suas peças por meio de lojas próprias e/ou por meio de outros estabelecimentos em dois ou mais países, e (4) comercializar sua marca própria (MOORE et al., 2000).

Nesse sentido, Vicente (2009) cita que as empresas brasileiras estão buscando desenvolver suas estratégias com foco na comercialização de produtos com maior valor agregado e na valorização de marcas para determinados segmentos de médio e alto padrão aquisitivo, para desenvolver mercados entre fronteiras.

Apontamentos da Apex (2012) corroboram com os de Vicente (2009), pois, de acordo com a Agência de Promoção à Exportação, a moda brasileira nos últimos anos ganhou destaque no mercado externo em função das cores, da diversidade e da ousadia dos produtos elaborados no Brasil. Reflexo desse movimento pode ser observado pela crescente participação do país em eventos do calendário internacional de moda, assim como as criações de designers que podem ser encontradas em butiques de cidades como Nova Iorque, Paris Londres, Tóquio e Pequim (APEX, 2012).

Logo, Vicente (2009) aponta que as principais empresas de moda brasileira em processo de internacionalização, estão participando de importantes eventos lançadores de coleções como o São Paulo Fashion Week, e também feiras internacionais por meio do Projeto TexBrasil (TEXBRASIL, 2012).

Com isso, de acordo com a Abit (2012), a moda brasileira passou a ganhar espaço no mercado mundial, destacando-se o design de moda praia, jeans e casa. Atualmente, formam-se profissionais em mais de 100 escolas e faculdades de moda no Brasil, tendo como resultado que a moda nacional passou a figurar entre as cinco maiores Semanas de Moda do mundo junto as de Paris, Nova Iorque, Londres e Milão (APEX, 2012). 
O ano de 2005 representa um marco para a internacionalização da moda brasileira, pois, segundo Leitão (2009), no ano do Brasil na França, a moda brasileira passou a buscar visibilidade internacional por meio da divulgação de sua produção no exterior, sobretudo na França. O começo do século XXI também é caracterizado pela busca da inserção de temas relacionados à cultura nacional, por meio da utilização de referências do Brasil em coleções de moda (LEITÃO, 2009).

Por fim, Manetti (2006) aponta que empresas brasileiras que buscam competir no segmento de moda no mercado internacional devem se apoiar tanto no produto biquíni (moda praia) e ou em produtos diferenciados, com trabalhos artesanais e peças de edição limitada.

A partir do que foi discorrido, assume-se, para fins desta pesquisa, que o mercado da moda é grande e competitivo. Que o Brasil está tentando ganhar espaço no mercado internacional, no entanto, os agentes ofertantes da indústria da moda encontram diversas barreiras (conforme explicado no item 2.2.1) para competir entre fronteiras.

Por outro lado, o consumidor de moda compra este tipo de produto movido tanto por motivos racionais quanto por emocionais (FEGHALI, 2008; FRINGS, 2001). Assim, entende-se que uma forma de cativar os consumidores pertencentes ao mercado internacional a comprar produtos de moda brasileira é por meio da oferta de produtos diferenciados. Logo, a diferenciação da oferta por meio da imagem do país de origem pode representar uma fonte de vantagem competitiva no mercado internacional da moda. Por isso, a próxima parte da fundamentação teórica centrou-se na literatura sobre a brasilidade e seus atributos no segmento em estudo.

\subsection{A Brasilidade}

Antes de se discorrer sobre a Brasilidade na Moda, faz-se necessário compreender o conceito de Brasilidade. No entanto, esse termo é um tanto indefinido, sendo reconstruído constantemente na literatura, uma vez que está em permanente formulação. Neste estudo, entende-se a Brasilidade como o conjunto de características da cultura e da identidade brasileira que formam a imagem do país. Logo, essa parte da fundamentação teórica buscou levantar as principais características da cultura brasileira, apoiando-se nas interpretações de 
diversos estudiosos e, depois, relacionou-as com o segmento da moda.

Observa-se que o debate sobre a construção da brasilidade e suas implicações é antigo, representado como tema central de vários estudos, como se verá adiante. Nota-se, porém que os estudos que se dedicam ao desenvolvimento e compreensão do termo e dos componentes que integram a cultura brasileira são pouco valorizados. Um dos motivos pode ser atribuído ao fato de que os brasileiros, conforme aponta Schwarz (1987, p. 29), se entendem como "postiços inautênticos" e imitadores da vida cultural que levam e, por isso, podem pensar que não têm uma origem que mereça ser estudada. Schwarz (1987) denomina esse sentimento como um mal-estar do brasileiro. Para o último autor, essa experiência cultural brasileira tem sido objeto de reflexão crítica desde os tempos da independência e foi interpretada de diversas maneiras, sob a ótica dos cosmopolitas, nacionalistas, românticos, naturalistas, modernistas, de esquerda, de direita entre outros.

Para Burity (2002) é perceptível o interesse evidenciado pelas ciências sociais contemporâneas pelo tema Cultura, esse mesmo interesse é perceptível com relação ao desenvolvimento de modelos de análise cultural. O autor afirma que a busca pelo entendimento da cultura se trata de uma tendência que vai além do território nacional, assim como, atravessa fronteiras linguísticas nas sociedades ocidentais.

Ortiz (2006) aponta que os diversos autores que têm trabalhado a temática concordam que a cultura brasileira e a identidade nacional são distintas das dos outros povos e países. No entanto, não basta tomar-se o partido de que o povo brasileiro é diferente, há que se compreender quais aspectos identificam a cultura brasileira (ORTIZ, 2006).

Dentre os principais estudos sobre as referências culturais brasileiras, destacam-se as tradicionais obras Raízes do Brasil de e Casa Grande \& Senzala. O autor da primeira obra, Sérgio Buarque de Holanda, foi um dos estudiosos que mais influenciaram na busca pela percepção da identidade brasileira (FINESTRALI; GARRIDO, 2010). Holanda (1971) destacou em sua obra, duas principais características da brasilidade: a falta de hierarquia e a ociosidade. Para Holanda (1971), a falta de hierarquia foi herdada dos Portugueses e da sua estrutura sócio-política, refletindo na sociedade brasileira, na fragmentação e na falta de coesão na vida social. Finestrali e Lapuente-Garridor (2010) afirmam que tal característica ainda permanece no Brasil contemporâneo, tendo como fruto um país heterogêneo e 
multifacetado, capaz de produzir vasta gama de manifestações que diferem da cultura material, tendo como conceito subjacente o de unidade na diversidade, que, segundo os autores, deve ser propagado por empresas brasileiras no exterior por meio, tanto de políticas públicas quanto por marcas e produtos.

Retomando os apontamentos de Holanda (1971), destaca-se outra característica brasileira citada pelo autor, a ociosidade, representando uma tendência ao desleixo. Na opinião de Finestrali e Garrido (2010), a ociosidade não deve ser compreendida sob o prisma negativo, podendo abarcar o conceito do estilo de vida do povo brasileiro, que também é reconhecido como alegre e hospitaleiro, e ser utilizado em programas de marketing por organizações.

Outro autor que merece destaque no estudo sobre a brasilidade é Gilberto Freyre. Para Freyre (1995, p. 4), formou-se em 1532, no que o autor denominou como a América tropical "uma sociedade agrária na estrutura, escravocrata na técnica de exploração econômica, híbrida de índio - e mais tarde de negro - na composição". Freyre (1995) enfatizou em seus estudos as origens da cultura brasileira ao destacar: as características gerais da colonização portuguesa, assim como os papéis do indígena, do colonizador português e do escravo negro na construção miscigenada da sociedade brasileira. Logo, a Brasilidade para Freyre (2009) é um modo característico e específico de ser do povo brasileiro, resultado de sua história e miscigenação social e cultural.

Martins (2002, p. 67) corrobora com os apontamentos de Freyre (1995; 2009) ao citar que a brasilidade pode ser entendida "como um conjunto de significações identitários, ao mesmo tempo próximas e contraditórias". Para esse autor, o estudo sobre a brasilidade no campo intelectual, não é explorado como se deveria e, mesmo com a revalorização de trabalhos de Freyre e de Holanda, Martins (2002) acredita que os intelectuais resistem à busca da compreensão mais específica da cultura brasileira. O último autor a busca pelo sentimento de nacionalismo no Brasil, ainda hoje, mostra-se limitada, este comportamento se dá a partir da "experiência mercantilista e escravista colonial", ou seja, em função do sentimento de submissão, que o autor trata como a memória que se reproduz por meio das "instituições de poder centralizadas e de uma lógica hierárquica de dominação" (MARTINS, 2002, p. 82).

Outro estudioso, esse de origem estrangeira, que se dedicou a compreender a história e a formação da cultura brasileira enquanto habitou o país, foi o Sociólogo Francês Roger 
Bastide. Em sua obra, Brasil Terra de Contrates, buscou retratar a pluralidade Brasileira em diversos sentidos, afirmando que o país se constitui a partir de três tipos de Brasil: "o Brasil indígena da Amazônia, do Mato Grosso e de Goiás; o Brasil branco do sul; e o Brasil negro, que seria antes de tudo o do litoral do Nordeste" (BASTIDE, 1980, p. 68). Bastide (1980) acrescenta à discussão da pluralidade cultural brasileira, outras nações, como a França, por suas ligações intelectuais e a Itália, em função dos imigrantes. O autor sugere ainda, que o Brasil tem posição importante no contexto mundial, devendo ocupar espaço entre o mundo anglo-saxônico e o mundo eslavo, pois é uma república jovem e que conseguiu unir, em sincretismo, civilizações diversas (indígenas, africanas e portuguesa).

Logo, Batiste (1980) reforça os apontamentos de Freyre (1995; 2009), Finestrali e Garrido (2010), Martins (2002) e Holanda (1971) ao defender que o Brasil pode ser visto como um "arquipélago de ilhas culturais dessemelhantes, embora banhadas pelas mesmas ondas e coroadas pelas mesmas estrelas" (BASTIDE, 1980, p.209), nação que combina elementos da cultura indígena, africana e europeia dando origem ao mito das três raças (ORTIZ, 2006). Um país, assim, caracterizado pela sua mistura de raças, diversidade demográfica e de recursos naturais, ou mesmo, marcado pelo hibridismo, conforme aponta Lucas (2010) com relação aos conceitos que referem-se ao complexo processo de misturas de culturas.

Essa linha de pensamento também é seguida por Caldas (2006) em seu estudo sobre a conceptualização dos perfis dos brasileiros. Para Caldas (2006), a cultura brasileira deve ser entendida como um produto social múltiplo e flexível, e não como um constructo estável e homogêneo. Dentre os elementos da cultura nacional brasileira identificados em seu estudo, Caldas (2006), cita três principais: 1) a representação da natureza hierárquica no trabalho que é enraizada em função da forma como o país foi colonizado; 2) a personificação, ou seja, a ideia de que as relações sociais e organizacionais não são reguladas somente pelo poder mas também pelos relacionamentos pessoais que transcendem as relações organizacionais, e 3) a ambiguidade, que pode ser exemplificada por meio do jeitinho brasileiro - prática social que visa encontrar um modo de contornar regras.

Colaborando para a formalização dos elementos que compõem a identidade cultural brasileira, o antropólogo Roberto DaMatta (2001), buscou, a partir da Antropologia Social - a qual assume uma visão da sociedade aberta e relativizada pela comparação - refletir sobre alguns aspectos da sociedade brasileira que são valorizados pelo povo, com intuito de compreender 
os elementos que fazem da nação o Brasil. Na ótica desse autor o Brasil "é país, cultura, local geográfico, fronteira e território reconhecidos internacionalmente, e também casa, pedaço de chão calçado com o calor de nossos corpos, lar, memória e consciência de um lugar com o qual se tem uma ligação especial, única, totalmente sagrada"(DAMATTA, 2001, p.11-12).

Em seu estudo, DaMatta (2001), centra-se em: apontar a riqueza da pluralidade da cultura brasileira; valorizar as pequenas "nações" dentro do mesmo país e analisar como essas se inter-relacionam, formando uma pátria, indo ao encontro às citações de Bastide (1980), sobre as "ilhas culturais". Para isso, DaMatta (2001) interpreta a identidade brasileira por meio dos desdobramentos de ações que fazem parte da condição humana: a forma como se deve comer, dormir, trabalhar, reproduzir-se e rezar. Nesse sentido, o autor faz uma reflexão sobre como tais ações são realizadas pelos brasileiros: a sua rotina entre casa, rua e trabalho; a ilusão das relações raciais (não há uma classificação racial formalizada, mas o preconceito); a culinária e o convívio familiar; as diferenças entre as festas de ordem e o carnaval (momento de liberdade e experimentação de excessos sem culpa); o jeitinho brasileiro com tom de malandragem e a religiosidade do povo brasileiro.

Com isso, DaMatta (2001) considera que o Brasil não pode ser entendido de modo unitário, mas sim relacional, reafirmando o apontamento dos outros autores citados nessa sessão. Por fim, DaMatta (2001) argumenta que o brasileiro deveria explorar sua capacidade de sintetizar, relacionar e conciliar, para criar zonas e valores ligados à esperança, à alegria e ao futuro, no sentido de utilizá-las nas diversas esferas da vida (cultura, política, religião, economia e relações interpessoais).

Diante dos apontamentos, alguns autores defendem que a utilização de referências da cultura das cinco regiões brasileiras em produtos pode agregar valor a esses, representando potencial oportunidade para empresas que buscam conquistar mercados internacionais. Finestrali e Garrido (2010) sugerem que a associação de referências da identidade brasileira pode ser uma forma eficaz de diferenciar produtos brasileiros em mercados internacionais. Morace (2009) sustenta tais apontamentos, ao afirmar que o Brasil apresenta valores que são reconhecidos no mundo todo que podem gerar grande oportunidade ao país no momento em que disseminá-los por meio de produtos.

Morace (2009) cita como valores brasileiros: a alegria de viver; a espontaneidade nos 
relacionamentos humanos; a simplicidade no cotidiano; o acesso a uma experiência que proporciona felicidade para todos (carnaval). Esse autor também considera os valores de neutralidade dos produtos, tais como o frescor no consumo (por meio das frutas exóticas e desconhecidas em outras localidades); a riqueza e a variedade das cores; os sorrisos e a sensualidade dos corpos, enfim, a naturalidade do ambiente e das pessoas.

Visando compreender a Brasilidade na contemporaneidade de modo a fornecer um panorama geral sobre os atributos marcantes de cada região que compõem o país e subsídios para empresas que buscam utilizar referências da cultura brasileira em seus negócios em transações internacionais, o Sebrae, em 2002, realizou a pesquisa Cara Brasileira.

Para o Sebrae (2002) as características brasileiras mais fortes e evidentes podem e devem ser valorizadas na construção de uma imagem positiva da nação. A Instituição, no entanto, afirma ser uma tarefa complexa definir algo tão distinto e heterogêneo e, por isso, defende que a diversidade do país abarca enorme potencial de geração de negócios (SEBRAE, 2002).

Com isso, para orientar a análise do estudo, o Sebrae decidiu utilizar um esquema derivado da pesquisa antropológica, a partir do qual foram classificados os traços mais importantes da identidade brasileira, a saber: a natureza; a cultura material (a adaptação coletiva, os produtos e as técnicas utilizadas para realização dos mesmos); a cultura social (por meio das manifestações econômicas, da diferenciação social, das formas de agrupamento, a educação, as relações sociais, a forma de organização do tempo, os ritos, o controle social), e a cultura ideal (a partir da comunicação, das conscientização em relação à natureza, ao homem, à regulação, aos valores, às formas expressivas).

Os resultados do estudo do Sebrae (2002) indicam que a Cultura Brasileira é receptiva à incorporação de diversas manifestações culturais sem sentir-se ameaçada, pois a convivência multirracial e multicultural é um traço próprio da cultura nacional. O estudo aponta também que o Brasil é caracterizado pela "inespecifidade", própria da diversidade cultural do país, e ainda conta com condições geográficas, climáticas e históricas que figuram como fontes para a criação de elementos que caracterizam o "espírito brasileiro", configurando ao país uma forte marca cultural. $\mathrm{O}$ estudo buscou caracterizar a cultura brasileira em diversas dimensões, denominado como patrimônio natural e cultural: as possibilidades de valorização. Tais dimensões estão resumidas no quadro 3. 
Quadro 3 - Dimensões da Cultura Brasileira

\begin{tabular}{|c|c|c|}
\hline Dimensão & Atributo & Características \\
\hline \multirow{4}{*}{$\begin{array}{l}\text { A } \\
\text { diversidade } \\
\text { harmoniosa }\end{array}$} & $\begin{array}{l}\text { A identidade } \\
\text { Cultural }\end{array}$ & Multicultural; multirracial; miscigenação benéfica;"inespecificidade”. \\
\hline & $\begin{array}{l}\text { Solidariedade e } \\
\text { índole relacional }\end{array}$ & $\begin{array}{l}\text { Importância das relações sociais; repúdio das pessoas ao } \\
\text { individualismo; vida centrada no relacionamento social, no vínculo } \\
\text { entre as pessoas e entre estas e meio ambiente; acolhimento ao } \\
\text { estrangeiro; cordialidade; "calor humano"; lealdade; personalidade; } \\
\text { respeito com os amigos; repúdio ao isolamento; necessidade de ser } \\
\text { amigo da pessoa com quem se faz negócios. }\end{array}$ \\
\hline & $\begin{array}{l}\text { Sincretismo } \mathrm{e} \\
\text { religiosidade }\end{array}$ & $\begin{array}{l}\text { Ideia unitária do Brasil, projetando imagens do português, do índio e } \\
\text { do negro; religiosidade múltipla e integrada. }\end{array}$ \\
\hline & $\begin{array}{l}\text { Adaptabilidade } \\
\text { e abertura ao } \\
\text { novo }\end{array}$ & $\begin{array}{l}\text { O "jeitinho brasileiro" de ser, próprio do meio em que se encontra, } \\
\text { buscando harmonizar contrastes, superar regras de uma maneira que } \\
\text { não caracterize a culpa. }\end{array}$ \\
\hline \multirow[t]{2}{*}{$\begin{array}{l}\text { Imagem } \\
\text { unitária e } \\
\text { diversidade } \\
\text { interna }\end{array}$} & $\begin{array}{l}\text { Os elementos } \\
\text { caracterizadores } \\
\text { de uma imagem } \\
\text { unitária }\end{array}$ & $\begin{array}{l}\text { Língua; aspectos ligados à natureza (o sol, a natureza, o país tropical } \\
\text { orgânico, as pedras preciosas e semipreciosas e as madeiras); aspectos } \\
\text { ligados ao físico (pele morena ou escura, sensualidade e culto à saúde } \\
\text { e ao corpo); aspectos ligados à características psicológicas e } \\
\text { comportamento (hospitalidade, sociabilidade, abundância, } \\
\text { generosidade, bom humor, alegria, otimismo, espontaneidade, } \\
\text { criatividade, abertura à inovação); aspectos ligados às manifestações } \\
\text { coletivas (pluralismo cultural, o barroco, o modernismo, a música - } \\
\text { bossa nova, o samba e o carnaval, o futebol, as telenovelas e a } \\
\text { capoeira). }\end{array}$ \\
\hline & $\begin{array}{l}\text { O problema da } \\
\text { especificidade }\end{array}$ & $\begin{array}{l}\text { Dificuldade em configurar uma imagem unitária do Brasil, em função } \\
\text { de elementos que contribuem para uma imagem abrangente do Brasil, } \\
\text { por meio dos traços - geográficos, culturais e sociais - que são } \\
\text { fortemente ligados a realidades locais de caráter específico (floresta } \\
\text { amazônica, o pantanal mato-grossense, a cultura negra, a cultura } \\
\text { indígena, a cultura do interior, as expressões musicais de regiões } \\
\text { específicas). }\end{array}$ \\
\hline $\begin{array}{l}\text { A } \\
\text { Brasilidade } \\
\text { entre a } \\
\text { tradição e a } \\
\text { Inovação }\end{array}$ & $\begin{array}{l}\text { Tradição } \\
\text { Inovação }\end{array}$ & $\begin{array}{l}\text { País jovem mostra-se aberto e receptivo a inovações. A tradição } \\
\text { brasileira pode ser definida pela sua capacidade ilimitada de } \\
\text { adaptação, de aceitação, reciclagem e adequação ao novo. Os } \\
\text { brasileiros, sem ponderar as possíveis implicações, unem a novidade } \\
\text { à tradição. }\end{array}$ \\
\hline \multirow{3}{*}{$\begin{array}{l}\text { A } \\
\text { Valorização } \\
\text { das } \\
\text { especificida } \\
\text { des culturais }\end{array}$} & A Natureza & $\begin{array}{l}\text { Diversidade e exuberância dos ambientes - rios e cascatas, praias, } \\
\text { mar, ilhas, pantanais, florestas, bosques - fonte de desenvolvimento } \\
\text { de turismo, qualidade estética e fármaco-terapêutica. }\end{array}$ \\
\hline & $\begin{array}{l}\text { O prestígio das } \\
\text { expressões } \\
\text { artísticas }\end{array}$ & $\begin{array}{l}\text { Artistas de prestígio: na literatura (Guimarães Rosa, Machado de } \\
\text { Assis e Jorge Amado); na poesia (João Cabral de Mello Neto e Carlos } \\
\text { Drummond de Andrade); no cinema (Mário Peixoto e Walter Salles); } \\
\text { na arquitetura (Oscar Niermeyer e Paulo Mendes da Rocha); na } \\
\text { pintura (Segall, Portinari e Antônio Dias); nas instalações (Helio } \\
\text { Oiticica), no teatro (Nelson Rodrigues) e na música popular (Bossa } \\
\text { Nova). }\end{array}$ \\
\hline & $\begin{array}{l}\text { As expressões } \\
\text { da vida coletiva }\end{array}$ & $\begin{array}{l}\text { Manifestações populares diversas, como: o forró do nordeste, as } \\
\text { praias, o carnaval, as celebrações de rua na Bahia, o Círio de Nazaré } \\
\text { em Belém, o réveillon no Rio de Janeiro, os grandes eventos } \\
\text { musicais, o candomblé e as manifestações de catolicismo. }\end{array}$ \\
\hline
\end{tabular}

Fonte: Autora, elaborado a partir de Sebrae (2002)

De acordo com o estudo do Sebrae (2002), a imagem do Brasil no exterior será valorizada somente a partir do momento em que o país se perceber de modo positivo, identificando o 
valor daquilo que é característica própria de seu povo. Indo ao encontro desse apontamento, Ortiz (2006, p. 39) afirma que "o mito das três raças não consegue ainda se ritualizar, pois as condições materiais para a sua existência são puramente simbólicas", com isso, entende-se que o valor da cultura mestiça brasileira será reconhecido, somente a partir do momento em que as condições simbólicas forem identificadas pelo seu povo e transformadas em condições materiais. Por isso, o Sebrae (2002) buscou elencar os pontos fortes e deficientes do Brasil, em ordem de importância, conforme apresentado no quadro 4.

Quadro 4 - Pontos Positivos e Negativos da Cultura Brasileira segundo pesquisa Cara Brasileira do Sebrae

\begin{tabular}{|c|c|}
\hline Eorto & \\
\hline $1-\mathrm{O}$ pluralismo racial e cultural; & $\begin{array}{l}\text { 1- A falta de auto-estima, a valorização apenas do } \\
\text { que vem de fora, resultante de pobreza cultural; }\end{array}$ \\
\hline $\begin{array}{l}2 \text { - Os elementos culturais provenientes de } \\
\text { tradições e experiências de vida autenticamente } \\
\text { populares; }\end{array}$ & $\begin{array}{l}2 \text { - A falta de confiança nas autoridades e no } \\
\text { governo, tendo como consequência a desconfiança } \\
\text { geral em relação às entidades públicas; }\end{array}$ \\
\hline $3-\mathrm{A}$ alegria e o otimismo; & 3 - Um certo desprezo pela técnica; \\
\hline $\begin{array}{l}4 \text { - As características pluralistas e sincréticas da } \\
\text { cultura; }\end{array}$ & $\begin{array}{l}\text { 4- A ideia de malandragem como necessidade de } \\
\text { tirar proveito de tudo, sobretudo dos humildes; }\end{array}$ \\
\hline 5- A ênfase nos relacionamentos pessoais; & $\begin{array}{l}\text { 5- A escassa divulgação do trabalho cultural } \\
\text { brasileiro em todos os segmentos; }\end{array}$ \\
\hline 6 - A hospitalidade e a cordialidade; & $\begin{array}{l}\text { 6-O personalismo arrogante, que se coloca acima } \\
\text { da lei; }\end{array}$ \\
\hline $\begin{array}{l}7-\text { A criatividade (cultural, econômica e } \\
\text { tecnológica) }\end{array}$ & $\begin{array}{l}7 \text { - A convicção de que todos se enganam para } \\
\text { ganhar mais dinheiro; }\end{array}$ \\
\hline & $8-$ A ignorância como "profissão de fé"; \\
\hline & $\begin{array}{l}9 \text { - A desonestidade em nome da família e dos } \\
\text { amigos; }\end{array}$ \\
\hline & $\begin{array}{l}10-\text { A falta de compromisso em relação aos } \\
\text { acordos firmados. }\end{array}$ \\
\hline
\end{tabular}

Fonte: Autora, elaborado a partir de Sebrae (2002)

A partir do entendimento acerca dos principais achados da pesquisa realizada pelo Sebrae (2002), verificou-se que esses vão ao encontro dos apontamentos da maioria dos autores citados anteriormente nessa sessão.

A partir da revisão da literatura sobre a Brasilidade, assumiu-se para efeitos deste estudo, os apontamentos de Bastide (1980), Freyre (2009), Martins (2002), DaMatta (2001), Morace (2009) e Finestrali e Garrido (2010). As opiniões desses autores junto à pesquisa qualitativa do Sebrae (2002), são tidas como complementares e serviram como base para o entendimento de Brasilidade nessa pesquisa.

Logo, assume-se para fins deste estudo, a Brasilidade como o conjunto de características da 
cultura e da identidade brasileira que formam a imagem do país. Assim, as características que formam a imagem do Brasil consideradas neste estudo são: a miscigenação de raças; a vasta gama de manifestações culturais; a sensualidade e beleza da mulher brasileira; a afetividade e a hospitalidade; a desigualdade social; a natureza; o clima tropical; as belezas naturais; a alegria de viver; a espontaneidade nos relacionamentos humanos; a simplicidade no cotidiano; o acesso a uma experiência que proporciona felicidade para todos (carnaval); a riqueza e a variedade das cores; os sorrisos e a naturalidade do ambiente e das pessoas e a ambiguidade do brasileiro (jeitinho brasileiro).

Como o tema desta pesquisa centrou-se na utilização da imagem do país de origem, por meio de atributos de brasilidade, em produtos de moda como fonte de vantagem competitiva no mercado internacional, o próximo passo do estudo foi buscar referências bibliográficas que explorassem os atributos de brasilidade moda, os quais foram delineados no item seguinte.

\subsubsection{A Brasilidade e a Moda}

Conforme discorrido no item anterior, o Brasil é caracterizado por sua cultura metarracial por sobrepor considerações de origens e situações raciais (FREYRE, 2009). Tal característica pode ser utilizada como repertório para criação, assim, Freyre (2009) sugere que a miscigenação deve ser utilizada como base para um novo papel da arte brasileira, que deve conciliar criações, artes, arrojos modernos por meio da sua harmonização com os gêneros miscigenados de beleza feminina. Para esse autor, o Brasil começa a conciliar a sua criatividade com a crescente capacidade tecnológica para industrializar e comercializar entre fronteiras produtos, que conceitua como da criatividade artística brasileira.

De acordo com Dalpra (2009, p.15) o Brasil é um país com cerca de 8 milhões de $\mathrm{Km}^{2}$ 8.511.965 Km² segundo Euromonitor (2012) - em extensão territorial e é habitado por uma população de aproximadamente 190 milhões de Brasileiros com "rostos que carregam traços de inúmeros países do mundo", seguindo os apontamentos de Rybalowski (2008), de que o Brasil é um país que caracteriza-se pela sua riqueza de variedade cultural e de expressões em função de sua extensão continental, o que o torna objeto de inspiração. E assim, Leitão (2009), Simai (2011) e Nadaff (2001) apontam para a importância do movimento de “abrasileiramento", ou seja, da busca pela construção das raízes brasileiras e apropriação das 
referências culturais nacionais. De acordo com Nadaff (2001) o momento é de abrasileirar e de sugar a criatividade originária de várias localidades do país e da tríade racial.

De acordo com a Abest (2012), os designers Brasileiros possuem uma capacidade criativa que é muito diversa, possibilitando representar não só produtos de estilo brasileiro, mas diversos enfoques por meio da liberdade de expressão e do seu próprio estilo nas criações.

No entanto, a formalização do conceito de brasilidade na moda e de suas referências ainda mostra-se em construção, nesse sentido, Chataignier (2010) afirma que não é fácil encontrar alguma obra brasileira que concatene os movimentos da moda, assim como seus códigos genéticos, os quais promovem revoluções no modo de vestir e na maneira de usar. Portanto, para se conseguir ter entendimento sobre os atributos de brasilidade na moda, faz-se necessário compreender a formação da moda brasileira, aspecto que será tratado, no item seguinte.

\subsubsection{A Moda Brasileira e a Brasilidade na Moda}

Para Chataignier (2010) a moda faz parte da cultura brasileira. De acordo com essa autora, indícios da criatividade e da arte da moda nacional já podiam ser vistos antes do país levar o nome de Brasil, por meio do traçado feito de fibras têxteis de origem vegetal, legado dos índios (CHANTAIGNIER, 2006).

Por outro lado, Castilho e Garcia (2001) apontam que frequentemente levantam-se questionamentos sobre a real existência da moda brasileira, cujo resgate de suas origens parece ser tão frágil. Avelar (2009) também questiona se seria possível determinar uma moda com identidade brasileira quando o debate atual sugere as produções em âmbito internacional.

Para Castilho e Garcia (2001) por décadas o brasileiro se indagou sobre o percurso, significado e sobre a real existência da moda brasileira, ignorando, por vezes, que mesmo nas cópias de grandes concorrentes internacionais existissem marcas culturais que revelam suas adequações (ou inexistência delas), as relações com o espaço, como o clima e com uma estética originária da miscigenação, que permeiam singularidades e geram a particularização da cultura brasileira (CASTILHO; GARCIA, 2001). 
Nesse sentido, Sabrá (2010) defende que a história responde por si, apontando que o Brasil conta com uma identidade cultural originária da mistura de três raças, conforme abordado anteriormente, com isso, o autor acredita que em toda a história da indumentária brasileira, recorreu-se à brasilidade, seja na "força da leveza, das raízes tão diversas, da docilidade quente do clima, das formas femininas, do dna da virilidade dos homens, da beleza da natureza" (SABRÁ, 2010, p.5).

Entretanto, para Avelar (2009) o processo de caracterização da moda brasileira é decorrente da história da formação da sociedade. De acordo com a autora, aprofundando-se na história brasileira consegue-se entender as razões pelas quais o brasileiro tem apego ao estrangeiro e explica que até o início do século XIX, antes da vinda da Família Real ao Brasil, a sociedade brasileira caracterizava-se como colonial e contentava-se com a extração predatória de suas matérias-primas e com a exportação da produção agrícola, aspectos que não contribuíam para a valorização de quaisquer elementos locais.

No entanto, após a chegada da Família Real, além da sociedade passar a realizar cópias dos modelos portugueses, os hábitos dos brasileiros passaram a ganhar características voltadas para o exterior, enaltecendo-se o que era trazido de outro país. Avelar (2009) complementa afirmando que durante todo o império até a metade do século XX a moda brasileira se baseou em criações europeias, sendo, de forma desproporcional, submissa à moda deste continente.

Algumas pesquisas acadêmicas no campo em estudo buscam detalhar, na medida do possível o processo de legitimação da moda no Brasil, que começou a ganhar, de forma discreta, características próprias a partir da década de 20 do século passado (1920), momento em que as indústrias têxteis nacionais começaram a nivelar sua capacidade de produção de tecidos às concorrentes europeias e às americanas, ou seja, estavam aptas a produzir bens equivalentes com preço competitivo (NEIRA, 2008; BONADIO, GUIMARÃES, 2010). Essa década é marcada pelo movimento modernista, pela semana da arte moderna em 1922, com a antropofagia (VILLAÇA, 2007) em que personalidades atuantes no segmento (editores de revistas de moda e dirigentes têxteis) começaram a se indagar se o mercado brasileiro têxtil deveria continuar seguindo as referências estéticas estrangeiras que chegavam ao Brasil por meio do cinema e revistas, uma vez que as características climáticas e culturais do país eram (e são) distintas das do sistema de criação-consumo de moda europeu (NEIRA, 2008). 
Como não havia uma história cultural no Brasil que estimulasse a criação, o segmento têxtil brasileiro continuou seguindo os padrões da estética europeia o qual se tornou uma referência absoluta no avançar da industrialização de têxteis e moda a partir de 1920 (NEIRA, 2008). Além disso, era considerado elegante, por parte das elites formadoras de opinião e consumidoras de moda, trajar-se de acordo com as referencias parisienses (BONADIO, GUIMARÃES, 2010). Logo a moda brasileira nessa época, se caracterizava por ser cópia dos europeus adaptada climaticamente (NEIRA, 2008), sendo a preocupação inicial a questão do clima (BONADIO, GUIMARÃES, 2010). Tais apontamentos encontram apoio nas citações do estilista Dener (in DÓRIA, 1998), de que a moda brasileira nasceu da necessidade climática, esse estilista afirmava que a moda nacional é tropical e, por isso, os tecidos mais leves e estamparias mais vivas deveriam e devem fazer parte do vestir do brasileiro.

Bonadio e Guimarães (2010) afirmam que mesmo com o fato de a indústria têxtil e de confecção ter se nivelado às concorrentes estrangeiras na década de 20 , a moda nacional entre 1930 e 1940, não expressava grandes movimentos e as revistas brasileiras de moda - na década de 40 - ainda dedicavam-se a apresentar a moda internacional.

No entanto, diante de tal conjuntura, o artista gráfico Alceu Penna, por meio de seus desenhos impressos na revista $O$ Cruzeiro, começou a propor um estilo brasileiro de moda (BONADIO, GUIMARÃES, 2010; SCHEMES, 2008), idealizando um dos primeiros exemplos de “estetização alegórica do Brasil na forma de roupas” (NEIRA, 2008, p. 2), o qual foi potencializado pelo seu sucesso no exterior, o figurino de Carmen Miranda. O traje de Carmen Miranda, que era caracterizado por frutas e balangandãs, foi levado para outros países, ajudando a construir o mito brasileiro por meio de uma estética tropical, coincidindo com a representação do Brasil desde a época de seu descobrimento (NEIRA, 2008).

Nesse sentido, o figurino carregado por essa artista brasileira, assim como os demais motivos explorados por Alceu Penna em suas ilustrações - o malandro, o calçadão de Copacabana, o chintz e a baiana (BONADIO, GUIMARÃES, 2010) - deram indícios da "constituição da imagem visual da brasilidade" na moda (NEIRA, 2008, p.4), tornando-se mais tarde "símbolos de brasilidade e seriam utilizados inúmeras vezes pela moda brasileira contemporânea no intuito de delinear um estilo nacional para a moda" (BONADIO, GUIMARÃES, 2010, p.155). 
De acordo com Messias (2008), somente na década de 60 que a moda no Brasil começou a ser, de fato, estruturada. Isto, segundo Messias (2008), aconteceu em função da chegada da indústria francesa - de fibras sintéticas e tecidos - Rhodia ao mercado brasileiro que, para difundir sua produção no novo mercado seguiu uma estratégia sugerida pelo publicitário Lívio Rangan, a qual se apoiava na produção de editoriais de moda e de desfiles que tinham como objetivo associar a invenção da moda brasileira às peças fabricadas com os produtos da Rhodia (MESSIAS, 2008). Como resultado, a vinda da Rhodia ao Brasil, estimulou o consumo de roupas em função da diminuição de parte dos custos de produção (matéria prima), assim como, propiciou, por meio do trabalho de Livio Ragan, a difusão da ideia da moda inspirada na tradição cultural e nas artes brasileiras (MESSIAS, 2008).

De acordo com Neira (2008), a Rhodia buscou realizar uma associação entre a arte brasileira e sua matéria-prima. Para tornar isso possível, explorou em editoriais de moda e em desfiles, elementos que conferissem brasilidade, tais como: a tropicália, a cultura caipira, o futebol, as paisagens naturais do país, os patrimônios históricos e o trabalho de artistas plásticos brasileiros na estamparia de tecidos (MESSIAS, 2008). A empresa Francesa realizou desfiles anualmente entre 1963 e 1970, na Fenit - Feira Nacional da Indústria Têxtil, criada em 1958 (MESSIAS, 2008) e ainda levou criações nacionais para serem desfiladas na Europa, nos Estados Unidos e no Japão ao associar-se à Revista $O$ Cruzeiro e à companhia aérea Varig (NEIRA, 2008). Cabe destacar que entre 1960 e 1970, o Brasil passou pelo golpe e Ditadura em 64, regime que passou a ser ainda mais restritivo em 68 com o AI-5. Neste contexto, Villaça (2007) aponta que a escolha de um estilo amplia-se, sendo no Brasil especificado por meio do Tropicalismo.

Em 1970 o conceito sobre a moda brasileira, se refletia somente em imagens, tendo assim, uma conotação beirando o folclore (NEIRA, 2008). Destaca-se, nesse período, o trabalho realizado pela mineira Zuzu Angel. De acordo com Villaça (2007), Zuzu explorou materiais nacionais, deu início a valorização de marcas brasileiras ao colocar sua etiqueta do lado de fora e, vinculou sua criação com representações do país, ao fazer alusões gráficas à morte de seu filho morto no regime militar. Ainda segundo Villaça (2007), nesta década, os costureiros já delineavam a moda nacional, apesar das cópias que ainda mostravam-se presentes, os trabalhos dos brasileiros passavam a ser apresentados em revistas femininas.

De acordo com Messias (2008), a década de 80 foi marcada pela constituição do Grupo 
Mineiro de Moda, pelo Grupo São Paulo de Moda e a Cooperativa de Moda. Porém, de acordo com a autora, somente na década de 90 que foi possível criar um calendário unificado de moda no Brasil, o qual, posteriormente conseguiu se integrar à agenda internacional de semanas de moda. Cabe destacar que até o final de 1980, os criadores brasileiros eram protegidos contra os produtos importados (AVELAR, 2009), proteção que pode ter lhes gerado comodidade.

Outro aspecto importante referente aos anos 80 é que, somente em meados dessa década que começaram a ser criados cursos de moda pelas instituições de ensino superior (PIRES, 2007), logo, a cultura de criação e desenvolvimento de produtos de moda assim como a identidade da moda brasileira, começaram a ser delineadas somente no final do século XX (BRAGA, 2006; COSTA, 2011).

Já, nos anos 90, em função da abertura do mercado, os estilistas brasileiros passaram a concorrer, de forma mais intensa, com grifes internacionais, o que demandou o reposicionamento de suas marcas e coleções, sendo que uma alternativa utilizada por muitos deles, foi a de buscar referências nos estereótipos da brasilidade (MESSIAS, 2009). De acordo com Avelar (2009) o mercado brasileiro como todo - o segmento do moda se incluía nele - não estava estruturado para concorrer com empresas internacionais, assim, os empresários brasileiros perceberam que para concorrer no mercado global não poderiam continuar copiando sem a adoção de recursos tecnológicos de produção.

Nesse sentido, Villaça (2007) aponta que a discussão sobre a identidade nacional começou a ser incitada entre estilistas, fotógrafos, produtores de moda, entre outros e o Brasil passou a ter sucesso no prêt-à-porter (peças de moda prontas para vestir) de Paris. Além disso, o corpo da mulher brasileira passou a ser objeto de desejo e progressivamente "instala-se o ir e vir do nacional e do estrangeiro no campo da moda, por ocasião dos desfiles" (VILLAÇA, 2007, p. 63). Avelar (2009) complementa os apontamentos de Villaça (2007), defendendo que nesse contexto o artesanato brasileiro começou a ser visto sob outra ótica, uma vez que o país não tinha uma cultura de criação e, assim, a utilização do artesanato passou a ser o ponto de partida para a criação com diferencial.

No entanto, Avelar (2009) pondera que a moda brasileira não implica necessariamente na utilização do artesanato, ou seja, o artesanato constitui uma dentre as diversas formas de 
buscar a particularidades que tornam uma criação original. Nesse sentido, não é a única, mas contribui fundamentalmente para o enriquecimento de coleções e imprime em peças parte da complexidade da cultura brasileira (AVELAR, 2009).

Seguindo a incorporação dos elementos da cultura brasileira na moda, Messias (2008; 2009) destaca o trabalho do designer Tufi Duek na década de 90, e aponta que esse criador colaborou para a discussão sobre a identidade brasileira na moda brasileira nessa década, por meio da utilização de referências da brasilidade em sua coleção, desfilada em 1994 e intitulada "Brasil, mostra a sua Cara". De acordo com Messias (2008; 2009) esse designer continuou buscando referencias no universo cultural brasileiro: em 2000, explorando a temática Carmen Miranda; em 2003 tendo como motivo uma obra de Jorge Amado (Dona Flor e seus dois maridos) e, em 2007 fez referências a Oscar Niemeyer. Alevar (2009) destaca o trabalho de Lino Villaventura, designer que, segundo a autora, recorre ao artesanato de forma inovadora.

Com a chegada do século XXI, o movimento de globalização se intensificou, nesse sentido Villaça (2007, p. 63) cita que cresceu a preocupação com a imagem do Brasil, país que deve ser explorado como um "celeiro de criatividade e talentos nos mais diversos campos". Com isso, essa autora aponta para a tendência da utilização do imaginário da arte no segmento da moda e sugere o empréstimo do campo artístico. Centeno (2010) reforça os apontamentos de Villaça (2007) ao defender que a nova representação do Brasil deve alicerçar-se nas novas regras do mercado globalizado, no sentido da busca pelo reencontro com as raízes históricas do país, mediante a utilização de ferramentas como o design para fixar originalidade às produções locais.

De acordo com Leitão (2009) o segmento em questão ainda está buscando construir raízes brasileiras a partir de narrativas explicitas que fazem parte do imaginário nacional e internacional, sobre sociedade e o povo brasileiro - conforme explorado anteriormente neste estudo. Leitão (2009) defende que o desenvolvimento da brasilidade na moda é caracterizado pela vontade de distinguir-se com uma produção autenticamente nacional.

Assim, Braga (2010) complementa a visão de Leitão (2009) e de Centeno (2010) ao citar que a ação de reconhecimento das características locais e aplicação das mesmas em produtos consiste no ato de agregar valor simbólico, reconhecendo o valor cultural daquela localidade. 
Esse autor aponta que os avanços tecnológicos e industriais tornaram o trabalho manual mais raro e mais procurado como forma de valorização cultural. Com isso, Braga (2010) pondera que a realidade imposta pela globalização, demanda que a diferenciação de qualquer produto deva primar pela valorização das características locais, ou seja, da cultura específica onde o produto foi elaborado.

Os apontamentos de Rybalowski (2008) seguem o mesmo raciocínio de Braga (2010), ao citar que um novo conceito de produto de moda que retoma formas, técnicas e aparência artesanal, surge a partir de uma reavaliação das limitações impostas pela racionalidade econômica da produção industrial. A autora acrescenta que o produto de moda com aspecto de artesanato prêt-à-porter, é manufaturado com requinte e cuidado, ao utilizar aviamentos e acabamentos especiais, agregando, portanto, ao produto qualidade de ordem estética, comercial e conceitual. Logo, Rybalowski (2008) acredita que o aspecto artesanal do que é ou parecer ser feito à mão, persiste como forte apelo para o consumidor, e acrescenta que a produção industrial com aura individual é produzida por criadores brasileiros.

Por fim, Centeno (2010) cita que somente a partir do ano 2000 que marcas e designers começaram a imprimir em suas coleções características mais contemporâneas e menos caricatas da cultura nacional, citando como exemplos: Osklen, Ronaldo Fraga, Lino Villaventura, Gilson Martins e Isabela Capeto. Tal desdobramento pode ter sido fruto das incitações sobre a identidade nacional da moda nos anos 90, conforme apontado por Villaça (2007) e da valorização do artesanato local como ponto de partida para oferecer ao mercado produtos de moda originais (AVELAR, 2009).

A compreensão sobre a trajetória do segmento da moda no Brasil permitiu a identificação de pesquisadores que abordam, em seus estudos, atributos de Brasilidade na moda. Tais atributos e estudos são explorados no item seguinte.

\subsubsection{Atributos de Brasilidade na Moda}

Para Feghali (2004), no segmento em estudo, o Brasil apresenta conceitos que remetem ao lema de curtir a vida, emergindo no contexto global, como uma alternativa ao expressar o oposto do comum, desfilando "modelos saudáveis que moldam o corpo e brincam com 
motivos e cores alegres, refletindo uma cultura assimilada como divertida" (FEGHALI, 2004, p.147).

De acordo com a Apex (2012) a moda brasileira tem ganhado espaço no mercado internacional, isso em função das cores, da ousadia e da diversidade das tradições culturais e do estilo de vida de uma nação miscigenada que são incorporados aos produtos. Segundo a Apex (2012), a riqueza de matérias-primas encontradas no Brasil, configura elemento estimulador da criatividade dos estilistas, tais como: fibras, gemas, metais, rendas e couros. Com isso, reforça-se a necessidade de buscar o entendimento do conceito de brasilidade na moda.

Em algumas pesquisas, identifica-se a busca pela formalização operacional do termo em estudo. Lucas (2010) cita que a moda no Brasil é um desfile de mestiçagem, reunindo rendas, bordados, chita com flores grandes coloridas, folhagens tropicais e frutas vistosas. No entendimento de Avelar (2009), os produtos brasileiros precisam agregar aspectos de originalidade em relação às criações de outros países. A autora aponta que a experimentação de alguns aspectos abre caminho para a diferenciação, esses elementos são: tecidos, formas e volumes, cores e justaposição de todas essas características.

Neira (2008, p.1) se aprofunda na busca pelo entendimento da Brasilidade na moda e corrobora com os apontamentos de Lucas (2010) e Avelar (2009) ao defender que o ideal nacionalista é traduzido na moda por meio de cores, volumes e formas que são próprios da "gramática visual da moda". Com isso, a última autora acredita que a moda brasileira é configurada pela utilização de cores primárias e secundárias, traços simplificados por meio de ferramental artesanal que resgatavam o aspecto da natureza tropical e adornos com detalhes de semente, penas, escamas, conchas ou contas.

Além disso, Neira (2008, p. 5) destaca a presença de formas reveladoras decotadas, curtas, esvoaçantes ou mesmo entreabertas, com características de peça de acabamento finalizado à mão, por meio de "amarrados, desfiados, tintos desuniformemente", lembrando, em parte, a nudez indígena. Logo, Neira (2008) defende que o conceito da moda brasileira deve resultar das características materiais bem definidas, tanto em sua materialidade (tecidos e adornos), quanto em sua forma modelada (o desenvolvimento e a confecção de cada peça). Nesse sentido, a autora argumenta que a moda brasileira se caracteriza a partir de algumas 
especificidades que a distingue de modas de outras nacionalidades e que se define em função do lugar ocupado pelo país.

Leitão (2009) aborda outra especificidade da cultura brasileira que é utilizada em demasia pelos criadores brasileiros. A autora centra-se no estudo sobre a utilização de elementos que fazem referência à fauna e a flora. Leitão (2009) entende que a natureza brasileira é exuberante e que é uma representação sedutora do país, sobretudo em outros mercados, podendo inspirar formas e cores na composição de imagens em estampas. A autora cita exemplos de referências da natureza que podem e que são utilizadas na moda, separando em dois movimentos distintos. Um sendo caracterizado pelo uso de matérias primas naturais como: pedras, contas de madeira, sementes, fios de palha; e o outro, que busca inspirações em representações da natureza por meio da utilização de imagens de flora e fauna em estampas, bem como a utilização de formas que as reproduzem em peças (exemplos peças com estampas de folhagens, frutas, coqueiros, flores, onça, papagaios, tucanos ou peças bordadas com araras em brilhos e lantejoula).

Seguindo a mesma linha de pensamento, Silveira, Pinheiro e Goya (2009) acrescentam ao debate ao defenderam que a criação da imagem do Brasil deve alicerçar-se na valorização da cultura nacional e no uso racional dos materiais relacionados ao design ecológico e inovador. Os apontamentos de Silveira et al. (2009), Neira (2008) e de Leitão (2009), confirmam, portanto, as citações de Freyre (2009), de que a Brasilidade na moda está na ecologia tropical e na miscigenação por meio de formas, cores e aparências.

No entendimento de Morace (2009) a brasilidade apresenta-se na moda por meio de cortes e tonalidades cromáticas tropicais, simplicidade, criatividade entre arte e matéria, na ironia e alegria de viver que são expressas em peças descontraídas com formas e texturas leves, as quais são comercializadas em lojas por moças e rapazes sorridentes, que transferem suas qualidades humana e relacional ao produto por meio de sorrisos naturais e gentileza. Com isso, Morace (2009) aponta atributos tangíveis e intangíveis da brasilidade na moda.

Castilho e Garcia (2001) contribuem para a construção do conceito ao citarem alguns elementos que fazem parte da brasilidade na moda, tais como: renda de bilro, labirinto, linho, cambraia de linho, bordados, filé, artesanato produzido à base de fibras de buriti, estamparia, textura (lãs trabalhadas, acrílico rústico). Braga (2010) também acrescenta ao 
desenvolvimento do conceito ao apresentar os seguintes aspectos que podem ser utilizados para inspiração na moda brasileira: bordado, fiação, renda, cestaria, encadernação, tipografia, gravura, entalhe, cerâmica, culinária, práticas religiosas e folclóricas.

Rybalowski (2008) apresenta temas da cultura brasileira que podem ser explorados e aplicados na moda, a saber: as manifestações culturais; os elementos naturais e as técnicas tradicionais. Fitas do Senhor do Bonfim, sementes, conchas, palhas diversas, rendas, tricô, crochê, aplicação de aviamentos, bordados, botões, entre outros. São alternativas que, segundo a autora, permitem ampliar as opções do processo criativo e acrescenta que "a viabilização e a utilização desses recursos não industrializados possibilitam uma linguagem e uma expressão únicas, características do país e diferenciadas da produção repetitiva e homogênea que segue as tendências estabelecidas” (RYBALOWSKI, 2008, p.107).

Aguiar e Caldas (2006) acrescentam que elementos da cultura indígena também fazem parte da brasilidade na moda e apontam que, por mais que as vestes dos índios sejam mínimas, vários de seus elementos foram incorporados pela sociedade e pela moda, como: a diversidade de materiais, peças, bijuterias, tatuagem, adornos, enfeites e vestes. As autoras apresentam alguns insumos de origem indígena que são e que podem ser utilizados como fonte de inspiração para produtos de moda, tais como: a carnaúba de onde se extrai sua palha para fazer vestes, madeira, conchas, sementes, dente de animais, dentre outros. Assim, os elementos citados podem ser utilizados na fabricação de bijuterias com sementes de plantas, e em macramés (técnica artesanal executada por meio de nós) de materiais vegetais (AGUIAR, CALDAS, 2006).

Centeno (2010) defende que a brasilidade deve ser apropriada pelo mercado e, para isso, dividiu os produtos que fazem referência à cultura brasileira em três categorias, denominandoos de:

1) "Os velhos repaginados": técnicas artesanais que haviam sido esquecidas em algumas partes do país e que estão sendo utilizadas novamente por designers conhecidos no mercado de moda brasileiro, contemplando rendas, crochê, os bordados, os fuxicos, retalhos, patchwork, nozinhos, além da chita e das sandálias havaianas;

2) "os símbolos nacionais": forma de conciliar as referências da cultura nacional com à modernidade por meio dos elementos que fazem menção à geográfica do país, como a natureza, o uso das cores verde e amarela; 
3) "temáticas ligadas ao país": são elementos que são facilmente identificados e reconhecidos, que estabelecem uma relação direta com o Brasil, como as praias, os coqueiros, as favelas, o samba, a cultura indígena e africada, a religiosidade e as imagens de Carmen Miranda.

Centeno (2010, p.8) aponta que os criadores brasileiros têm buscado referências na cultura brasileira, transformando-as com profissionalismo e cita que elementos como "a arte e o artesanato, o folclore, os grandes clássicos da literatura e seus personagens os discursos do morro e do asfalto, do carnaval e do funk, a essência do caipira e do homem da cidade" deixam de figurar somente no espaço da cultura popular e passam a ser referência para a criação de produtos no segmento da moda.

As especificidades que fazem parte da moda Brasileira levaram a Abest (Associação de Estilistas Brasileiros) e a Apex (Agencia Brasileira de Exportações e Investimentos) a firmar uma parceria dando origem ao projeto $+\mathrm{B}$, o qual tem como objetivo transformar o país em repertório criativo (ABEST, 2012). Deste modo, o $+\mathrm{B}$ parte do pressuposto de enxergar a beleza individual do brasileiro e sua miscigenação mostrando-se enriquecedora para a pesquisa e que pode ser utilizada como referência para os designers que buscam criar coleções e produtos de moda e design. O grande desafio do projeto tem sua consistência nas múltiplas culturas do país, ou seja, em descobrir na imensidão do seu território, as riquezas culturais e transformá-las em conceito que representam a simplicidade e a alegria de viver do brasileiro. Para materializar a pesquisa o projeto criou um caderno bilíngue que tem edições anuais desde 2008 (ABEST, 2012).

Com base nos apontamentos dos estudiosos em moda e brasilidade, montou-se o quadro 5 com o intuito de organizar os elementos que compõem a brasilidade por atributos. Tal quadro foi utilizado na pesquisa empírica. Como uma das questões de pesquisa da fase empírica do estudo era a de identificar quais são os atributos que compõem a imagem do país de origem no segmento da moda, elencou-se aos atributos de brasilidade na moda encontrados na literatura e buscou-se verificar em campo se novos atributos poderiam ser acrescentados ao quadro, conforme poderá ser observado no capítulo de análise dos dados. 
Quadro 5 - Atributos de brasilidade na moda

\begin{tabular}{|c|c|}
\hline Atributo & $\begin{aligned} \text { Elementos } \\
\end{aligned}$ \\
\hline Estilo de vida & $\begin{array}{l}\text { Lema de curtir a vida (FEGHALI, 2004); que transmite ousadia e a diversidade de tradições } \\
\text { culturais; o estilo de vida de uma nação miscigenada que são incorporados aos produtos } \\
\text { (APEX, 2012);Na ironia e alegria de viver (MORACE, 2009) }\end{array}$ \\
\hline $\begin{array}{l}\text { Representações } \\
\text { do Brasil e } \\
\text { símbolos } \\
\text { nacionais }\end{array}$ & $\begin{array}{l}\text { Inspirações em representações da natureza por meio da utilização de imagens de flora e } \\
\text { fauna (em estampas), a utilização de formas que as reproduzem em peças com estampas de } \\
\text { folhagens, frutas, coqueiros, flores, onça, papagaios, tucanos ou peças bordadas com araras } \\
\text { em brilhos e lantejoula (LEITÃO, 2009). A Ecologia tropical e na miscigenação (FREYRE, } \\
\text { 2009); inspiração em encadernação, tipografia, gravura, entalhe, cerâmica, culinária, práticas } \\
\text { religiosas e folclóricas (BRAGA, 2010); nas manifestações culturais (RYBALOWSKI, } \\
\text { 2008); Conciliação das referências da cultura nacional com à modernidade por meio dos } \\
\text { elementos que fazem menção à geográfica do país, como a natureza, o uso das cores verde e } \\
\text { amarela; elementos que são facilmente identificados e reconhecidos, que estabelecem uma } \\
\text { relação direta com o Brasil, como as praias, os coqueiros, as favelas, o samba, a cultura } \\
\text { indígena e africada, a religiosidade e as imagens de Carmen Miranda(CENTENO, 2010). }\end{array}$ \\
\hline Cores & $\begin{array}{l}\text { Motivos e cores alegres (FEGHALI, 2004; APEX, 2012; FREYRE, 2009), cores primárias e } \\
\text { secundárias (NEIRA, 2008), tonalidades cromáticas tropicais (MORACE, } \\
\text { 2009); coordenação e composição de cores (CASTILHO; GARCIA, 2001; DENER in } \\
\text { DÓRIA, 1998), }\end{array}$ \\
\hline $\begin{array}{l}\text { Matérias Primas } \\
\text { Naturais }\end{array}$ & $\begin{array}{l}\text { Fibras, gemas, metais (APEX, 2012); semente, penas, escamas, conchas, contas (NEIRA, } \\
\text { 2008); pedras, contas de madeira, sementes, fios de palha (LEITÃO, 2009); artesanato } \\
\text { produzido à base de fibras de buriti (CASTILHO, GARCIA, 2001); os elementos naturais: } \\
\text { sementes, conchas, palhas diversas (RYBALOWSKI, 2008). }\end{array}$ \\
\hline $\begin{array}{l}\text { Aplicações e } \\
\text { Técnicas } \\
\text { artesanais }\end{array}$ & $\begin{array}{l}\text { Rendas (APEX, 2012; LUCAS, 2010); os bordados (LUCAS, 2010), acabamentos } \\
\text { manuais - amarrados, desfiados, tintos (NEIRA, 2008); Textura (lãs trabalhadas, acrílico } \\
\text { rústico), bordados, filé, renda de bilro, labirinto (CASTILHO, GARCIA, 2001); bordado, } \\
\text { fiação, renda, cestaria (BRAGA, 2010); técnicas tradicionais e utilização de rendas, tricô, } \\
\text { crochê, aplicação de aviamentos, bordados, botões, Fitas do Senhor do Bonfim entre outros. } \\
\text { (RYBALOWSKI, 2008); bijuterias com sementes de plantas, técnica dos indígenas e } \\
\text { macramés (técnica artesanal indígena executada por meio de nós) de materiais vegetais } \\
\text { (AGUIAR, CALDAS, 2006); rendas, crochê, os bordados, os fuxicos, retalhos, patchwork, } \\
\text { nozinhos (CENTENO, 2010). }\end{array}$ \\
\hline Tecidos & $\begin{array}{l}\text { Chita (LUCAS, 2010; CENTENO, 2010); linho (CASTILHO, GARCIA, 2001), tecidos } \\
\text { leves (DENER in DÓRIA, 1998), traçado de fibras têxteis vegetais (índios); cestaria, } \\
\text { ecológicos, algodão natural, fibra de buriti, linho, cambraia, chita, juta, (CHATAIGNIER, } \\
\text { 2006; FREYRE, 2009). }\end{array}$ \\
\hline Estampa & $\begin{array}{l}\text { Flores grandes coloridas, folhagens tropicais e frutas vistosas (LUCAS, 2010); traços } \\
\text { simplificados por meio de ferramental artesanal que resgatavam o aspecto da natureza } \\
\text { tropical (NEIRA, 2008); estamparia (CASTILHO, GARCIA, 2001); estamparias vivas } \\
\text { (DENER in DÓRIA, 1998), ilustrações de Alceu Penna como: o malandro, o calçadão de } \\
\text { Copacabana, o chintz e a baiana (BONADIO, GUIMARÃES, 2010) }\end{array}$ \\
\hline $\begin{array}{l}\text { Formas e } \\
\text { volumes }\end{array}$ & $\begin{array}{l}\text { O desenvolvimento e a confecção de cada peça, podendo ser: reveladoras decotadas, curtas, } \\
\text { esvoaçantes ou mesmo entreabertas, lembrando, em parte, a nudez indígena (NEIRA, 2008); } \\
\text { cortes, simplicidade, criatividade entre arte e matéria, peças descontraídas com formas e } \\
\text { texturas leves (MORACE, 2009) }\end{array}$ \\
\hline
\end{tabular}

Fonte: elaborado pela autora

A partir dos apontamentos, antes da pesquisa de campo, observou-se que a imagem do país de origem (Brasil) no contexto da moda é um constructo em desenvolvimento e que abarca atributos, os quais são as bases do conceito, a saber: estilo de vida do povo brasileiro, as representações do Brasil e símbolos nacionais; as cores; as matérias-primas naturais; as aplicações e técnicas artesanais; os tecidos; as estampas e as formas/volumes. 


\subsection{Síntese da fundamentação teórica}

A partir do arcabouço teórico apresentado nos itens anteriores, observa-se que o ambiente competitivo atual, caracterizado pela oferta de produtos e serviços superior a sua demanda e em que as operações são realizadas no âmbito global, fez com que as empresas passassem a entender e suprir os anseios dos consumidores, para manter uma posição competitiva vantajosa.

Viu-se, assim, que uma empresa consegue obter uma vantagem competitiva quando é capaz de gerar valor econômico superior ao de seus concorrentes (BARNEY; HESTRELY, 2007) quando entrega os mesmos benefícios que seus competidores, mas com custos menores (vantagem por meio da liderança de custos) ou quando entrega benefícios que excedam os disponibilizados pelos seus concorrentes (vantagem por meio da diferenciação) (WENCHENG et al.; 2011).

Logo, as empresas devem conquistar seus consumidores de modo a manter uma posição competitiva vantajosa, implementando estratégicas com base em vantagens competitivas de origem interna ou externa à organização e dependem da estratégia competitiva adotada pela empresa (LAMBIN, 2000; WEN-CHENG et al., 2011; PORTER, 1989). Como segmento em estudo é o da moda, indústria em que os consumidores são influenciados por benefícios e buscam expressar e construir sua personalidade por meio do vestuário (RYBALOWSKI, 2008), a fonte de vantagem competitiva que embasou o estudo é a externa, por meio da diferenciação.

A fundamentação teórica evidenciou as diversas formas de diferenciação que uma empresa pode utilizar para distinguir sua oferta, destacando-se, para fins deste estudo, a imagem do país de origem como forma de diferenciação da oferta (FINESTRALI; GARRIDOR, 2010; GIRALDI; TORNAVOI, 2004; 2005), uma vez que a pesquisa tem foco na moda no contexto do mercado internacional.

Posto isso, foram destacadas as características, a dinâmica, os agentes e o movimento de internacionalização da moda para familiarização com o segmento em estudo. Buscou-se também clarificar os atributos que compõem a imagem do país de origem, no caso do Brasil, por meio do estudo da brasilidade. Assim, foram expostos diversos pontos de vista sobre o 
termo e contextualizou-se a imagem do país de origem no segmento da moda, abordando-se os atributos da brasilidade na moda, que foram apresentados por estudiosos que desenvolvem pesquisas nesse segmento.

Quadro 6 - Referencias utilizadas na fundamentação teórica

\begin{tabular}{|c|c|}
\hline Tema & Fundamentação teórica \\
\hline 2.1 Competitividade & Porter (1999); Zatta et al. (2011); Bruno et al. (2009) \\
\hline $\begin{array}{l}\text { 2.1.1 Fontes de Vantagem } \\
\text { Competitiva }\end{array}$ & $\begin{array}{l}\text { Ansoff (1990); Toledo e Anselmo (2003); Porter (1989); Barney e Hesterly } \\
\text { (2007); Wen-Cheng et al. (2011); Lambin (2000); Day e Wensley (1988); } \\
\text { Cater (2003); Orsato (2006). }\end{array}$ \\
\hline $\begin{array}{l}\text { 2.1.1.1 Fontes de Vantagem } \\
\text { Competitiva Interna }\end{array}$ & $\begin{array}{l}\text { Lambin (2000); Porter (1989); Lambin (2000); Barney e Hesterly (2007); } \\
\text { Saes (2008). }\end{array}$ \\
\hline $\begin{array}{l}\text { 2.1.1.2 Fontes de Vantagem } \\
\text { Competitiva Externa }\end{array}$ & Porter (1989); Lambin (2000). \\
\hline $\begin{array}{l}\text { 2.1.1.3 Formas de } \\
\text { diferenciação }\end{array}$ & $\begin{array}{l}\text { Mintzberg (2006); Kotler e Keller (2006); Danskin et al. (2005); Wen- } \\
\text { Cheng et al. (2011); King e Lenox (2001); Orsato (2006); Elkinton (1994). }\end{array}$ \\
\hline $\begin{array}{l}\text { 2.1.1.4 Formas de } \\
\text { diferenciação no segmento do } \\
\text { moda }\end{array}$ & $\begin{array}{l}\text { Kikuchi e Silva (2011); Rybalowski (2008); Emerenciano e Pires (2006); } \\
\text { Rocha et al (2005); Danskin et al. (2005); Zatta et al. (2011); Brïdson e } \\
\text { Evans (2004). }\end{array}$ \\
\hline $\begin{array}{l}\text { 2.1.2 A imagem do país de } \\
\text { origem como fonte de } \\
\text { vantagem competitiva }\end{array}$ & $\begin{array}{l}\text { Finestrali e Lapuente-Garidor (2010); Giraldi e Tornavoi (2004;2005); } \\
\text { Schooler (1965); Giraldi et al. (2011a; 2011b); Agrawal e Kamakura } \\
\text { (1999); Gürhan-Canli e Maheswaran (2000); Kotler e Gertner (2002) } \\
\text { Al-Sulati e Baker (1998); Usunier (2006); Roth e Diamantopoulos (2009). }\end{array}$ \\
\hline $\begin{array}{l}\text { 2.2 Contextualização do } \\
\text { segmento de moda }\end{array}$ & Costa e Rocha (2009); IEMI (2011); Hansen (2004) \\
\hline $\begin{array}{l}\text { 2.2.1 Panorama do Mercado } \\
\text { do Moda }\end{array}$ & $\begin{array}{l}\text { Feghali (2004); Rech (2008); Braga (2006); IEMI (2011); BNDES (2009); } \\
\text { Costa e Rocha (2009); Abit (2011); Filho (2011 in IEMI, 2011); Zatta et a.l } \\
\text { (2011); Manetti (2006); Abest (2012). }\end{array}$ \\
\hline 2.2.1.1 Dinâmica do Setor & $\begin{array}{l}\text { Rocha et al. (2005); Goldsmith et al. (2012); Law et al. (2004); D’Almeida } \\
\text { (2008); Feghali (2004); Braga (2006) }\end{array}$ \\
\hline 2.2.1.2 Agentes do Setor & $\begin{array}{l}\text { Lambin (2000); Oliveira (2012); Apex (2012); Abit (2012); Apex (2011 in } \\
\text { IEMI, 2011); TexBrasil (2012); Abest (2010); Pires (2007); MDIC (2009); } \\
\text { Afonso (2010). }\end{array}$ \\
\hline 2.2.2 O consumidor de Moda & $\begin{array}{l}\text { Frings (2001); D'Almeida (2008); Braga (2004); Lage (2011); Durand } \\
\text { (1988); Armoni (2007); Konig (1969); Lipovetsky (2009); Cavalheiro } \\
\text { (2001); Freyre (2009), Nacif (2007); Feghali (2004;2008); Frings (2001); } \\
\text { Goldsmith et al (2012); Shim e Bickle (1994); Rybalowski (2008). }\end{array}$ \\
\hline $\begin{array}{l}\text { 2.2.3 O movimento de } \\
\text { internacionalização no } \\
\text { segmento do moda }\end{array}$ & $\begin{array}{l}\text { Messias (2009); IEMI (2011); Costa e Rocha (2009); Secani e Jorge (2005); } \\
\text { Abest (2012); Moore et al. (2000); Vicente (2009); Apex (2012); TexBrasil } \\
\text { (2012); Abit (2012); Leitão (2009); Manetti (2006) }\end{array}$ \\
\hline 2.3 A Brasilidade & $\begin{array}{l}\text { Schwarz (1987); Burity (2002); Ortiz (2006); Finestrali e Lapuente-Garidor } \\
\text { (2010); Holanda (1971); Freyre (1995; 2009); Martins (2002); Bastide } \\
\text { (1980); Caldas (2006); DaMatta (2001); Morace (2009); Sebrae (2002). }\end{array}$ \\
\hline 2.3.1 A Brasilidade e a Moda & $\begin{array}{l}\text { Braga (2010); Freyre (2009); Dalpra (2009); Euromonitor (2012); } \\
\text { Rybalowski (2008); Leitão (2009); Simai (2011); Nadaff (2001); Abest } \\
\text { (2012); Chataignier (2010). }\end{array}$ \\
\hline $\begin{array}{l}\text { 2.3.1.1A Moda Brasileira e a } \\
\text { Brasilidade na Moda }\end{array}$ & $\begin{array}{l}\text { Chataignier (2006; 2010); Castilho e Garcia (2001); Avelar (2009); } \\
\text { Sabrá(2010); Meira (2008); Bonadio e Guimarães (2010); Villaça (2007); } \\
\text { Dener (in DÓRIA, 1998); Schemes (2008); Messias (2008; 2009) Pires } \\
\text { (2007); Centeno (2010); Leitão (2009); Braga (2010); Rybalowski (2008). }\end{array}$ \\
\hline $\begin{array}{l}\text { 2.3.1.2Atributos da } \\
\text { Brasilidade na Moda }\end{array}$ & $\begin{array}{l}\text { Bonadio e Guimarães (2010); Feghali (2004; 2008); Apex (2012); Lucas } \\
\text { (2010); Avelar (2009); Neira (2008); Leitão (2009); Silveira et al. (2009); } \\
\text { Freyre (2009); Morace (2009); Castilho e Garcia (2001); Braga (2010); }\end{array}$ \\
\hline
\end{tabular}


Rybalowski (2008); Aguiar e Caldas (2006); Centeno (2010); Abest (2012).

Os temas que foram fundamentados, assim como os autores utilizados estão reunidos no quadro 6. 


\section{ASPECTOS METODOLÓGICOS DA PESQUISA EMPÍRICA}

De acordo com Sampieri, Collado e Lucio (2006), após a realização da pesquisa bibliográfica o pesquisador poderá julgar se é valido realizar uma pesquisa de campo sobre a temática estudada. Deve-se optar pelo enfoque e a natureza do estudo de acordo com o objetivo almejado.

Assim sendo, esse capítulo visa apresentar os aspectos metodológicos para o desenvolvimento da pesquisa empírica realizada, buscando, assim, apresentar a metodologia utilizada no estudo e os motivos para sua escolha.

\subsection{Natureza da pesquisa}

A natureza do estudo é exploratória, tipo de pesquisa que visa contribuir para a formalização do conhecimento do tema em estudo. Conforme citam Sampieri et al. (2006), os estudos exploratórios são utilizados quando o objetivo da pesquisa consiste em examinar um problema de pesquisa ou tema que foi pouco estudado e do qual se tem dúvidas.

Marconi e Lakatos (2010) defendem que o estudo exploratório tem como premissa a investigação de pesquisa empírica com objetivo de formular questões ou um problema, com tripla finalidade: desenvolver hipóteses, aumentar a familiaridade do pesquisador com um ambiente, fato ou fenômeno, para a que este possa realizar uma pesquisa futura com maior precisão, ou modificar e clarificar conceitos.

Assim sendo, optou-se pelo estudo exploratório uma vez que se buscou a literatura que relaciona as variáveis em estudo - imagem do país de origem, fontes de vantagens competitivas, moda, atributos de brasilidade e mercado internacional - porém, poucos estudos foram encontrados, não havendo corpo teórico robusto para se realizar um estudo quantitativo e descritivo.

Verificou-se assim, a incipiência da temática, uma vez que são escassos os estudos que contextualizam os atributos da imagem do país de origem como fonte de vantagem competitiva no contexto da moda brasileira, a partir de consultas realizadas em Banco de 
Dados Bibliográficos Dedalus (USP), nos Anais dos 7 colóquios de Moda, na Biblioteca Digital de Teses e Dissertações (USP), na biblioteca e na base de dados Ebsco, Jstor e Proquest da Fundação Instituto de Administração (FIA) e no Google Acadêmico. Nestas buscas, verificaram-se alguns estudos que tratam de parte das variáveis que a presente pesquisa busca relacionar como: a imagem do país de origem e fontes de vantagens competitivas; moda brasileira e internacionalização, sendo duas dissertações e duas teses.

\subsection{Abordagem da pesquisa}

De acordo com Sampieri et al. (2006) existem dois enfoques principais de pesquisa, o quantitativo e o qualitativo. O quantitativo busca responder às questões de pesquisa e testar hipóteses previamente estabelecidas, ao passo que o estudo qualitativo almeja descobrir e refinar questões de pesquisa (SAMPIERI et al., 2006). Assim, Marconi e Lakatos (2010) citam que o método qualitativo difere do quantitativo não somente por não empregar instrumentos estatísticos, mas também pelos instrumentos de coleta de dados.

Neste estudo, optou-se pela abordagem qualitativa. O estudo buscou identificar, analisar e interpretar dados e informações com diferentes graus de profundidade e complexidade. Logo, para esse tipo de estudo, Sampieri et al. (2006), assim como Marconi e Lakatos (2010), sugerem a abordagem qualitativa.

De acordo com Flick (2009), a pesquisa qualitativa é profunda, constituindo um método que vai além dos contextos especializados de pesquisa, ao buscar entender, descrever e, em algumas situações, explicar os fenômenos sociais intrínsecos de diversas maneiras diferentes, analisando experiências de indivíduos ou grupos, examinando interações e comunicações que estejam se desenvolvendo; e investigando documentos semelhantes de interações ou experiências, mostrando ser a abordagem adequada para os objetivos desta investigação. 


\subsection{O universo de pesquisa}

O universo da pesquisa empírica foi constituído por agentes de mercado, mais especificamente, agentes demandantes e agentes de apoio à internacionalização da moda brasileira e estruturação do segmento.

Os agentes demandantes entrevistados são representados neste estudo por compradores internacionais de moda (B2B), confeccionistas internacionais e por proprietários de pontos de vendas em que marcas brasileiras são comercializadas. São, portanto, profissionais que representam empresas internacionais do segmento de moda, que veem ao Brasil para realizar negócios no período da Fashion Week de São Paulo. Além dos compradores que participam dos eventos no Brasil, foram entrevistados outros compradores internacionais por intermédio dos agentes de apoio à inserção de produtos de moda no mercado internacional.

Foram entrevistados, também, agentes de apoio à internacionalização, que são profissionais que atuam na área de gestão e internacionalização da moda em associações do segmento, em consultorias e profissionais que participaram da estruturação do setor em estudo. São, portanto, profissionais que ocupam cargos estratégicos em associações do segmento, como Abit, Abest e Apex, assim como, profissionais que ajudam a estruturar o setor, tais como organizadores de eventos importantes para o ramo (Casa de Criadores e Mercado Mundo Mix).

\subsection{Definição da amostra de pesquisa}

A amostra é uma parcela convenientemente selecionada do universo, ou seja, é um subconjunto do universo (MARCONI; LAKATOS, 2010). Conforme apontam Godoi e Mattos (2006) a decisão da quantidade de pessoas a se entrevistar e quantas vezes entrevistar é uma decisão inevitável, chegando a ser incômoda.

Desse modo, no presente estudo, a amostra foi por conveniência do pesquisador. Foram entrevistados demandantes e de apoio à inserção do produto de moda no mercado internacional. Para seleção dos entrevistados, respeitaram-se alguns critérios, conforme 
indicado no quadro 7.

Quadro 7 - Critérios para seleção de entrevistados por unidade de pesquisa

\begin{tabular}{|c|c|}
\hline \multicolumn{2}{|c|}{ Unidade de pesquisa } \\
\hline $\begin{array}{l}\text { Agentes de Apoio à internacionalização e } \\
\text { estruturação do segmento }\end{array}$ & Agentes Demandantes \\
\hline \multicolumn{2}{|c|}{ Critérios } \\
\hline $\begin{array}{l}\text { Pertencer à comunidade de atores da moda que } \\
\text { tenham presença no mercado. }\end{array}$ & $\begin{array}{l}\text { Trabalhar no segmento da moda há, pelo menos, } 3 \\
\text { anos. }\end{array}$ \\
\hline Trabalhar no ramo há, pelo menos, 5 anos & $\begin{array}{l}\text { Comprar ou pesquisar a moda brasileira há, pelo } \\
\text { menos } 2 \text {, anos }\end{array}$ \\
\hline Ser influente no setor e formador de opinião & $\begin{array}{l}\text { Trabalhar em uma empresa que compre de marcas } \\
\text { Brasileiras há, pelo menos, } 2 \text { anos. }\end{array}$ \\
\hline $\begin{array}{l}\text { Já ter participado de algum processo ou transação } \\
\text { internacional no segmento em estudo }\end{array}$ & $\begin{array}{l}\text { Acessibilidade para conceder entrevista ou } \\
\text { responder ao questionário }\end{array}$ \\
\hline
\end{tabular}

Fonte: elaborado pela autora

No que se refere ao número de respondentes, buscou-se entrevistar tantos respondentes quantos fossem necessários para o pesquisador se familiarizar com o tema, conforme sugerido por Mattar (2007, p.11) “o número de entrevistas a realizar não é definido, e deverão ser realizadas tantas quantas forem necessárias".

\subsection{Definições teóricas e operacionais dos conceitos}

Considerando-se o problema de pesquisa proposto - Quais atributos da imagem do país de origem representam fonte de vantagem competitiva no mercado internacional? - e o contexto em que foi estudado, segmento da moda, fez-se necessária a definição dos seguintes termos: atributos da imagem do país de origem; fontes de vantagem competitiva; mercado internacional e moda.

\section{Atributos da imagem do país de origem:}

A imagem do país de origem refere-se ao resultado da sua geografia, história, música, arte, proclamações, cidadãos famosos entre outras características nacionais (KOTLER; GERTNER, 2002), assim como, às conotações simbólicas e emocionais do país de origem que o transformam em um atributo de imagem e interfere nas avaliações e decisões de compra que os consumidores fazem no tocante aos produtos fabricados naquele país (GIRALDI, 
TORNAVOI, 2004; 2005; GIRALDI et al., 2011a; GIRALDI et al., 2011b).

O estudo aborda os atributos do país de origem no contexto da moda, ou seja, atributos que resultam da imagem do Brasil que podem ser utilizados em produtos de moda. Assim sendo, considerou-se a definição de atributos da brasilidade na moda.

\section{Atributos de Brasilidade na moda:}

A brasilidade na moda consiste na presença de elementos que fazem referência a características peculiares da cultura e da identidade Brasileira em produtos e serviços no segmento da moda. Ou seja, versa sobre a utilização de atributos que compõem um estilo miscigenado, a partir da cultura das cinco regiões brasileiras. A Brasilidade também abrange atributos intangíveis como o estilo de vida do brasileiro, apresentando elementos que remetem ao lema de curtir a vida por meio da naturalidade do ambiente e das pessoas. Tal definição foi adaptada a partir da opinião de pesquisadores em moda e em comportamento e associações, como Feghali (2004), Abest (2012), Morace (2009), Rybalowki (2008), Avelar (2009) e Braga (2010).

Em termos operacionais, os atributos de brasilidade na moda consistem na utilização dos elementos em produtos de moda, os quais estão detalhados na fundamentação teórica: representações do Brasil e símbolos nacionais; cores; matérias primas naturais; aplicações e técnicas artesanais; estilo de vida do brasileiro; estampa; formas e cores. A definição operacional foi adaptada a partir da opinião de pesquisadores em moda e em comportamento, como Rybalowki (2008), Avelar (2009), Morace (2009), Castilho e Garcia (2001), Braga (2010), Dener (in DÓRIA, 1998), Neira (2008), Freyre (2009), Lucas (2010), Centeno (2010), Aguiar e Caldas (2006); Chataignier (2006) e Bonadio e Guimarães (2010). Cabe destacar que o estudo também busca identificar outros atributos que fazem parte do conceito de brasilidade na moda e que não foram identificados na revisão da literatura. 


\section{Fontes de Vantagens Competitivas:}

Uma empresa consegue obter uma vantagem competitiva quando é capaz de gerar valor econômico superior ao de seus concorrentes. Sendo o valor econômico conceituado como a diferença entre os benefícios percebidos pelo consumidor relacionados à compra de produtos/serviços de uma organização e o custo de produção e comercialização de tais produtos/serviços. Desse modo, a vantagem competitiva ocorre quando a empresa apresenta características ou atributos em seus produtos ou marca que lhe conferem certa superioridade em face aos concorrentes imediatos. Tais atributos podem ser próprios do produto ou decorrentes de serviços necessários ou agregados, ou ainda referentes aos modos de produção, distribuição ou venda do produto pela empresa. Nesse sentido, as vantagens competitivas podem ter origem externa ou interna à organização e dependem da estratégia competitiva adotada pela empresa. Os apontamentos encontram respaldo nas citações de Lambin (2000), Porter (1980; 1989); Mintzberg (2006) e Barney e Hesterly (2007).

O estudo aborda as fontes de vantagem competitiva de origem externa à organização, que, em termos operacionais, ocorrem por meio da adoção da estratégia de diferenciação, em que a empresa busca oferecer produtos/serviços de valor singular para os compradores (PORTER, 1989). A empresa pode diferenciar sua oferta: 1) por imagem; 2) por suporte; 3) por qualidade; 4) por design; 5) inovação; 6) sustentabilidade ou 7) pela imagem do país de origem (ORSATO; 2006; FINESTRALI; GARRIDO, 2010; GIRALDI; TORNAVOI, 2004; 2005; MINTZBERG; 2006; KOTLER, KELLER, 2006). A pesquisa considerou a forma de diferenciação por meio da imagem do país de origem, uma vez que o estudo abordou a competição no âmbito internacional.

\section{Mercado Internacional:}

O mercado internacional é composto por diferentes canais, compradores B2B e consumidores finais. Este estudo se limitará a pesquisar o mercado B2B. Em termos teóricos, B2B (Business to Business) diz respeito a transações entre empresas e é a nomenclatura atual para o que se denominava, até 1980, de mercado industrial. Atribui-se também o nome de mercado organizacional ou mercado entre empresas. Existem três tipos de mercado organizacionais: mercado revendedor, mercado governamental e mercado industrial (LAMBIN, 2000). 
Neste estudo, o B2B é representado pelo comprador internacional, o qual tem como objetivo a obtenção de ganho por meio da venda de produtos de moda (roupas) que foi comprado anteriormente. Esse mercado é formado por empresas que adquirem produtos com a finalidade de revendê-los em seus mercados de origem (LAMBIN; 2000; CAMPOMAR; 2012).

No âmbito operacional, o B2B internacional de moda, é representado por empresas compradoras de produtos brasileiros, ou seja, são empresas que adquirem produtos de moda brasileira (roupas), para ofertar aos consumidores finais e ou varejistas da localidade onde operam. São, portanto, agentes que se dispõem a vir ao Brasil participar de eventos de moda (Fashion Week) para comprar peças de moda, e empresas que exportam produtos e vestes de marcas brasileiras (associadas à Abit e Abest), por meio do projeto comprador da TexBrasil (projeto de incentivo à exportação no segmento do moda firmado entre a Apex e a Abit).

\section{Moda:}

Em termos teóricos, moda é o conjunto formado pelos elementos que compõem o traje e por acessórios que devem fixá-lo ou complementá-lo (NACIF, 2007). Para efeitos deste estudo, entende-se, no âmbito operacional, que a moda é composta por peças e coleções de vestes desenvolvidas e comercializadas por marcas e designers brasileiros, que ofertam produtos com valor agregado, ou seja, que buscam diferenciar sua oferta para competir no mercado internacional.

\subsection{Modelo conceitual teórico da pesquisa}

A partir da questão-problema apresentada no capítulo 1 e, também apresentada na sessão de definições de termos (3.4), elaborou-se um modelo conceitual teórico da pesquisa que contempla as variáveis do estudo e suas relações, conforme pode ser observado na ilustração 6. 


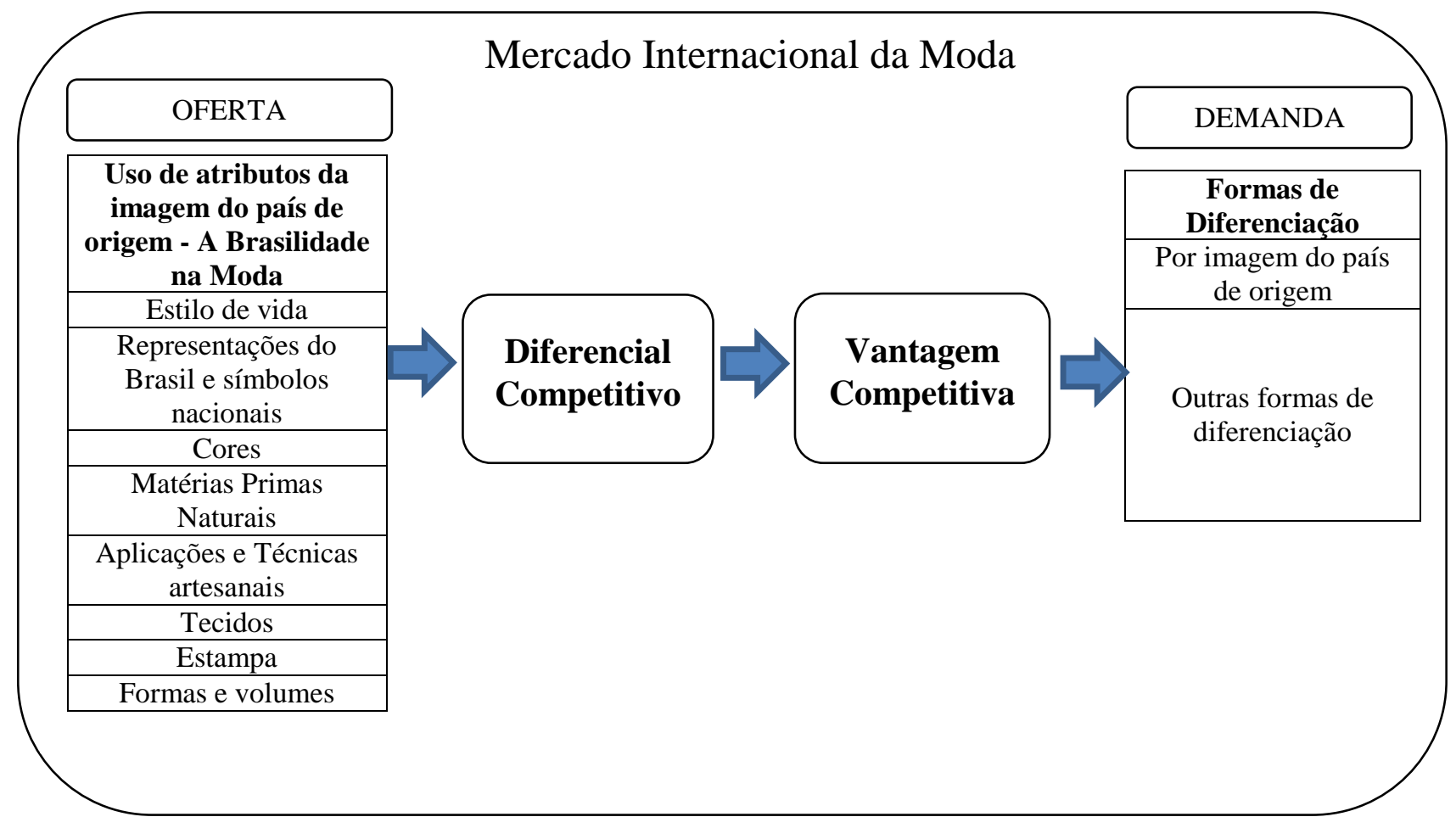

Ilustração 6 - Modelo conceitual teórico da pesquisa

Fonte: elaborado pela autora

\subsection{Coleta de dados}

A coleta de dados foi realizada por meio de entrevistas semiestruturadas, instrumento de coleta de dados que concede ao entrevistador liberdade para desenvolver cada situação na direção em que este considere adequada (MARCONI; LAKATOS, 2010).

Foi utilizada a pesquisa centralizada no problema, que se caracteriza por três aspectos centrais, a saber: 1) a centralização no problema (pesquisador voltado para um problema social relevante), neste estudo, a competitividade do segmento do moda brasileiro no contexto internacional; 2) orientação ao objeto (que os métodos sejam modificados ou desenvolvidos com respeito a um determinado objeto de pesquisa), nesta pesquisa, a imagem do país de origem no contexto da moda brasileira como fonte de vantagem competitiva; e, que seja orientada pelo processo (orientada no processo de pesquisa e no entendimento do referido objeto de pesquisa) (FLICK, 2009). 
Para tanto, utilizou-se um roteiro, ou guia de pesquisa, contendo os tópicos relativos ao problema que foi estudado (FLICK, 2009). Com esse instrumento, o entrevistador teve liberdade de fazer perguntas e flexibilidade para ordenar e elaborar perguntas durante a entrevista (GODOI; MATTOS, 2006). Elaborou-se dois roteiros de entrevista, um para os agentes demandantes e outro para os agentes de oferta e de apoio. Tais instrumentos foram elaborados a partir do arcabouço teórico e estruturados considerando-se as questões de pesquisa da fase empírica e a questão problema da dissertação.

\section{Quadro 8 - Temas abordados nos roteiros de entrevista}

\begin{tabular}{|l|l|}
\hline \multicolumn{1}{|c|}{ Agentes ofertantes e de apoio ao setor } & \multicolumn{1}{|c|}{ Agentes demandantes } \\
\hline Caracterização do agente & Caracterização do agente \\
\hline $\begin{array}{l}\text { Compreensão sobre os atributos que compõem } \\
\text { a imagem do país de origem no contexto da } \\
\text { moda, ou seja, brasilidade na moda. }\end{array}$ & $\begin{array}{l}\text { Atratividade para comprar produtos de moda } \\
\text { brasileira }\end{array}$ \\
\cline { 2 - 2 } Brasilidade na moda & $\begin{array}{l}\text { Diferenciação no produto de moda } \\
\text { imagem do país de origem no contexto da moda, ou } \\
\text { seja, brasilidade na moda. }\end{array}$ \\
\hline Brasilidade na Moda e diferenciação & $\begin{array}{l}\text { Atributos da brasilidade na moda como fonte de } \\
\text { vantagem competitiva }\end{array}$ \\
\hline
\end{tabular}

Logo, as entrevistas foram realizadas com base em dois roteiros de pesquisa muito semelhantes, com alguns ajustes (apêndice 1 e 2). Ambos os roteiros serviram de orientação para a condução da pesquisa empírica para responder a questão problema proposta. O quadro 8 reúne os temas abordados nos roteiros de entrevista.

Os instrumentos foram testados em junho de 2012 com dois estudantes de pós-graduação e com um gestor que atua no segmento em estudo. Alguns ajustes se fizeram necessários na forma da colocação das questões com relação à Brasilidade na moda e no tocante a forma de como abordar os fatores de diferenciação, sugeriu-se a linguagem empresarial à de estratégia. Recomendou-se também a inserção de uma tabela em que o entrevistador visualizava os atributos da brasilidade na moda para elaborar questionamentos sobre a importância de cada atributo da imagem do país de origem no contexto da moda e sua valorização por parte do mercado internacional. 


\subsection{Análise dos dados}

A sugestão de uma "nova realidade no texto produzido" (FLICK, 2009, p. 266), foi elaborada a partir da analise dos dados, que foi realizada por meio da análise de discurso, conforme poderá ser observado próximo capítulo. Essa metodologia de interpretação de dados mostrouse adequada para analise em função da coleta ter sido realizada mediante entrevistas, em que considerou-se o conteúdo da fala e, por isso, as interpretações foram embasadas nas transcrições das entrevistas (FLICK, 2009).

Gill (2002) aponta que a análise de discurso apresenta quatro principais temas: a preocupação com o discurso; a ênfase no discurso como uma forma de ação; a visão da linguagem como construtiva e construída; e a crença na organização retórica do discurso. A análise dos dados desta pesquisa foi pautada nesses temas e, a partir dos ensinamentos de Flick (2009) e de Gill (2002), seguiram-se quatro etapas para realização da análise de dados:

1) Transcrição das gravações das entrevistas e leitura das informações;

2) Codificação das informações em itens e subitens de acordo com os principais termos utilizados para alicerçar o estudo;

3) Análise e comparação dos resultados da investigação com os apontamentos identificados na teoria;

4) Descrição e comparação dos discursos dos entrevistados, para identificar padrões nos dados.

Para realizar a análise dos dados elaborou-se uma planilha eletrônica, na qual as respostas dos entrevistados foram organizadas em forma de matriz e puderam-se verificar os temas recorrentes nas respostas. As respostas obtidas por meio dos questionários respondidos por agentes demandantes também foram dispostos em uma planilha eletrônica para análise.

Os aspectos metodológicos do estudo empírico podem ser observados no quadro 9, que busca explicar de forma resumida e visual o que foi exposto até o momento sobre os procedimentos metodológicos. 
Quadro 9 - Síntese dos procedimentos metodológicos da pesquisa empírica

\begin{tabular}{|l|l|}
\hline \multicolumn{1}{|c|}{ Caracterização } & \multicolumn{1}{|c|}{ Aporte teórico } \\
\hline Natureza: exploratória & Sampieri et al. (2006); Marconi e Lakatos (2010). \\
\hline Abordagem: qualitativa & $\begin{array}{l}\text { Sampieri et al. (2006); Flick (2009); Marconi e } \\
\text { Lakatos (2010). }\end{array}$ \\
\hline $\begin{array}{l}\text { Amostra: agentes de mercado do segmento da } \\
\text { moda (compradores internacionais e agentes de } \\
\begin{array}{l}\text { apoio à inserção da moda brasileira no mercado } \\
\text { internacional). }\end{array}\end{array}$ & $\begin{array}{l}\text { Marconi e Lakatos (2010); Godoi e Mattos (2006); } \\
\text { Bauer e Aarts (2002); Mattar (2007). }\end{array}$ \\
\hline $\begin{array}{l}\text { Coleta de dados: entrevista semi-estruturada } \\
\text { (centrada no problema). }\end{array}$ & $\begin{array}{l}\text { Flick (2009); Marconi e Lakatos (2010); Godoi e } \\
\text { Mattos (2006). }\end{array}$ \\
\hline Análise dos dados & Flick (2009) e de Gill (2002). \\
\hline
\end{tabular}




\section{ANALISE DA PESQUISA EMPÍRICA}

O presente capítulo destina-se à apresentação da análise dos dados e está dividido em três partes. Inicia-se com as explicações sobre a coleta de dados, incluindo-se a caracterização dos entrevistados e a descrição das entrevistas. Na segunda parte analisam-se os dados por meio da análise de discurso, relatando-se os apontamentos dos entrevistados com relação à imagem do país de origem no contexto da moda brasileira e formas de diferenciação para a oferta no segmento da moda, assim como, confrontam-se os dados com o referencial teórico estudado. A parte final sintetiza os resultados do estudo.

\subsection{Realização das entrevistas}

As entrevistas foram realizadas em duas etapas, a primeira etapa entre Junho e Julho de 2012, época em que se realizaram dois eventos de moda: 1) o São Paulo Fashion Week - semana em que marcas e designers apresentam suas criações ao público e compradores por meio de desfiles e mediante show rooms para venda de coleções ; e 2) o Premiére Vision Brasil - feira em que fornecedores de jeans, moda urbana, fibras e fios, desenho têxtil, estamparia e aviamentos expõem seus produtos em stadings e recebem compradores.

Durante o período dos dois eventos acima descritos, foram entrevistados cinco agentes demandantes (compradores internacionais) e um agente de apoio (profissional que trabalha na Abit). Dentre os agentes demandantes, consideraram-se somente as entrevistas de três profissionais, pois os demais não respeitavam os critérios de seleção para entrevista por não conhecerem a moda brasileira, uma vez que estavam comprando pela primeira vez coleções de moda brasileira nos eventos.

Tais entrevistas foram realizadas presencialmente. Desse modo, para entrevistar os agentes demandantes, a pesquisadora esteve presente no stading da Abest/Abit durante os eventos, local em por onde os compradores passam e concedem entrevistas quando visitam o evento. Assim como, a pesquisadora deslocou-se até a Abit para realizar a entrevista com o agente de apoio. 
A segunda etapa da coleta de dados ocorreu entre outubro e novembro de 2012, época em que realizaram-se dois eventos de moda: uma nova edição do São Paulo Fashion Week, seguida da edição do Rio Fashion (semana que tem o mesmo objetivo que a São Paulo Fashion Week mas ocorre no Rio de Janeiro com os criadores e marcas que atuam no mercado carioca). Durante esse período forma entrevistados quatro agentes de apoio e um agente demandante.

Assim sendo, nove entrevistas foram realizadas, sendo cinco com agentes de apoio e quatro com agentes demandantes. O quadro 10 apresenta a qualificação dos nove respondentes válidos.

Quadro 10 - Qualificação dos entrevistados

\begin{tabular}{|c|c|c|c|c|c|}
\hline Nome & Entrevistado & Nacionalidade & $\begin{array}{c}\text { Nacionalidade } \\
\text { da empresa } \\
\text { em que } \\
\text { trabalha }\end{array}$ & $\begin{array}{l}\text { Tempo em } \\
\text { que trabalha } \\
\text { no segmento } \\
\text { da moda }\end{array}$ & Função atual \\
\hline $\begin{array}{l}\text { Fernando } \\
\text { Pimentel }\end{array}$ & A1 & Brasileiro & Brasileira & 35 anos & Superintendente da Abit \\
\hline $\begin{array}{l}\text { André } \\
\text { Hidalgo }\end{array}$ & A2 & Brasileiro & Brasileira & 15 anos & $\begin{array}{l}\text { Diretor da Casa de } \\
\text { Criadores }\end{array}$ \\
\hline $\begin{array}{l}\text { Antonio } \\
\text { Haslauer da } \\
\text { Costa }\end{array}$ & A3 & Brasileiro & Americana & 25 anos & Diretor da AHadvisoring \\
\hline $\begin{array}{l}\text { Evilásio } \\
\text { Miranda }\end{array}$ & A4 & Brasileiro & Brasileira & 6 anos & $\begin{array}{l}\text { Gerente de Moda e } \\
\text { Design da Abit }\end{array}$ \\
\hline Geni Rodia & A5 & Brasileira & Brasileira & 35 anos & $\begin{array}{l}\text { Consultora da Abit e } \\
\text { Coordenadora de Cursos } \\
\text { da Escola São Paulo }\end{array}$ \\
\hline Nic Cox & A6 & Inglês & Russa & 20 anos & $\begin{array}{l}\text { Comprador, jornalista e } \\
\text { produtor de moda }\end{array}$ \\
\hline Nancy & A7 & Peru & Peruana & 6 anos & $\begin{array}{l}\text { Compradora e designer } \\
\text { de moda }\end{array}$ \\
\hline Andrea Lopez & A8 & Colômbia & Colombiana & 3 anos & Designer de moda \\
\hline $\begin{array}{l}\text { Renoux } \\
\text { Hugues }\end{array}$ & A9 & Francês & Francesa & 4 anos & $\begin{array}{l}\text { Proprietário da Loja } \\
\text { Sable Chaud }\end{array}$ \\
\hline
\end{tabular}

Conforme sugerido por Flick (2009), as entrevistas foram gravadas, com o consentimento dos entrevistados, e a pesquisadora também documentou o processo de coleta de dados por meio de fichas de documentação - para documentar o contexto e a situação da coleta (FLICK, 2009), de modo que tais instrumentos foram consultados ao longo de todo o processo de análise dos dados. As gravações foram transcritas com o intuito de "[...] eliminar as imprecisões das anotações de campo e ampliar a possibilidade de acesso público dos resultados, com elevado detalhamento", conforme sugere Godoi (2006, p.314).

As duas primeiras entrevistas com agentes de apoio duraram em torno de uma hora e foram 
agendadas previamente. Ao passo que as três primeiras entrevistas com agentes de demanda foram realizadas durante as feiras, por isso, as entrevistas foram realizadas com os profissionais que se disponibilizaram a conceder informações no momento em que estavam trabalhando (selecionando coleções para comprar), logo, as entrevistas duraram menos tempo (em torno de 26 minutos). Em função disso, a pesquisadora percebeu a necessidade de entrevistar mais agentes. Assim, a pesquisadora contatou mais três agentes de apoio e um agente demandante e agendou estas entrevistas, sendo duas realizadas presencialmente e duas por Skype, que duraram cerca de uma hora. Utilizou-se o Skype como ferramenta de comunicação uma vez que dois agentes estavam em outros países (EUA e França).

Durante as entrevistas observou-se que os participantes mencionaram todos (oito) os atributos da imagem do país no contexto da moda que foram encontrados na literatura, no entanto, quatro atributos tiveram mais destaque. Além disso, os entrevistados mencionaram a Brasilidade na moda como fonte de vantagem competitiva. O quadro 11 apresenta os principais aspectos das entrevistas.

Quadro 11 - Aspectos relacionados às entrevistas

\begin{tabular}{|l|l|l|l|l|}
\hline Entrevistado & $\begin{array}{c}\text { Tipo de } \\
\text { entrevista }\end{array}$ & $\begin{array}{c}\text { Duração } \\
\text { da } \\
\text { entrevista }\end{array}$ & $\begin{array}{c}\text { Língua em que a entrevista } \\
\text { foi conduzida }\end{array}$ & $\begin{array}{c}\text { Total de atributos da imagem } \\
\text { do país de origem no contexto } \\
\text { da moda mencionados }\end{array}$ \\
\hline $\begin{array}{l}\text { Fernando } \\
\text { Pimentel }\end{array}$ & Presencial & $46 \mathrm{~min}$ & Portuguesa & 4 \\
\hline André Hidalgo & Presencial & $53 \mathrm{~min}$ & Portuguesa & 5 \\
\hline $\begin{array}{l}\text { Antonio } \\
\text { Haslauer } \\
\text { Costa }\end{array}$ & Skype & $57 \mathrm{~min}$ & Portuguesa & 4 \\
\hline $\begin{array}{l}\text { Evilásio } \\
\text { Miranda }\end{array}$ & Presencial & $58 \mathrm{~min}$ & Portuguesa & 4 \\
\hline Geni Rodio & Presencial & $76 \mathrm{~min}$ & Portuguesa & 4 \\
\hline Nic Cox & Presencial & $32 \mathrm{~min}$ & Inglesa & 5 \\
\hline Nancy & Presencial & $24 \mathrm{~min}$ & $\begin{array}{l}\text { Espanhola (auxílio } \\
\text { tradutora da ABIT) }\end{array}$ & 4 \\
\hline Andrea Lopez & Presencial & $22 \mathrm{~min}$ & $\begin{array}{l}\text { Espanhola (auxílio da } \\
\text { tradutora da ABIT) }\end{array}$ & 4 \\
\hline Renoux Hugues & Skype & $82 \mathrm{~min}$ & Inglesa & 6 \\
\hline
\end{tabular}

Ao longo das entrevistas os dados foram documentados por meio de gravações (gravação realizada durante as entrevistas), editados por meio da transcrição para a formatação de uma "nova realidade no texto produzido" conforme aponta Flick (2009, p. 266). A última fase foi elaborada a partir da análise dos dados, conforme apresentado no item seguinte. 


\subsubsection{Entrevistas com agentes de apoio}

Foram entrevistados cinco profissionais que atuam em associações ou instituições que apoiam o desenvolvimento da moda Brasileira e sua inserção no mercado internacional de modo a responder o problema proposto pelo estudo. A seguir serão apresentados os entrevistados e relatadas as entrevistas realizadas.

\section{Entrevistado A1 - Fernando Pimentel (ABIT)}

$\mathrm{O}$ agente de apoio identificado nesse estudo como Entrevistado A1, chama-se Fernando Pimentel e trabalha na ABIT (Associação Brasileira da Indústria Têxtil), sediada em São Paulo, como Diretor Superintendente da Associação desde 2005. A formação do entrevistado é em Economia e Administração e especialização em Marketing. Segundo relatado pelo entrevistado ele se considera um militante da indústria têxtil brasileira há trinta e cinco anos.

Segundo Pimentel, a sua trajetória profissional no segmento da moda iniciou-se de forma acidental. Seus familiares eram de Barbacena (Juiz de Fora), uma zona têxtil grande. Pimentel estagiou em diversas áreas de engenharia, para seguir a carreira do Pai, mas em um determinado momento, o pai de um amigo seu, Dr. Celso, o convidou para trabalhar na empresa que dirigia a Ferreira e Guimarães, uma empresa centenária que ainda atua no mercado. A primeira área em que o entrevistado trabalhou nesta indústria têxtil foi na de vendas, mas especificamente no segmento de pesquisa de mercado, área que não era comum de se ter em empresas na época. Depois Pimentel passou a trabalhar na área de economia e finanças com projetos (durante a década de 70, 80).

No ano de 1980, o proprietário da indústria, Dr. Celso faleceu, e o entrevistado passou a ser assessor da diretoria na área de economia e finanças, em seguida mudou de área e assumiu a área de vendas em produtos de estamparia. Depois assumiu toda área de produto (tintos, estampados, índigo). De modo que a experiência profissional do entrevistado é fundamentalmente no setor têxtil, sendo considerada por ele como uma experiência rica em um setor só, em diversas áreas na mesma empresa (produção, economia finanças, vendas, desenvolvimento de produto, pesquisa de mercado) o que proporcionou a ele a visão holística da empresa e do segmento da moda. 
O superintendente da Abit acredita que a moda brasileira reflete o povo que vive no Brasil, ou seja, aponta que é uma moda alegre, descontraída e que os brasileiros estão tendo, à medida que o país está crescendo econômica e socialmente, mais vontade de usar o que é feito no Brasil.

Pimentel ressalta que o país é composto por diversas realidades e culturas, cada estado revela uma cultura diferente. Assim, para ele a moda nacional deve se apropriar, de forma não caricata, dos elementos da cultura brasileira para fazer uma moda nacional que tenha uma linguagem universal. $\mathrm{O}$ entrevistado acredita que a identidade da moda brasileira está em processo de consolidação e que é importante utilizar referências locais, mas não deixar de pensar no âmbito global, ou seja, de que as ideias e inspirações são compartilhadas entre culturas e sociedades em torno do mundo.

O entrevistado comenta ainda que a moda brasileira ainda não se diferencia no mercado internacional de forma marcante, pois o processo de internacionalização é recente, teve início há uma década. Mas diz que a moda brasileira tem espaço no mercado internacional e que o mundo está observando o trabalho realizado por designers brasileiros. Para Fernando Pimentel, o Brasil é um país muito rico, em que designers podem se apropriar de diversos elementos da imagem do Brasil, como a biodiversidade, a fauna, a flora, a sustentabilidade. Além disso, acredita que a moda brasileira é uma moda leve e menciona os seguintes atributos como elementos diferenciadores de produto quando foi indagado sobre a brasilidade na moda: cores, estampas, estilo de vida e símbolos e manifestações culturais.

Pimentel menciona que há motivação por parte das marcas e designers brasileiros em se internacionalizar, mas que esse é um processo muito caro e que demanda aportes financeiros elevados. No entanto, governo e associações do segmento estão desenvolvendo um trabalho intenso de capacitação e qualificação de empresas para atender o mercado externo.

Para o entrevistado o produto de moda brasileira pode ter sua imagem consolidada no mercado internacional, a exemplo da moda Japonesa, por meio do estilo de vida do brasileiro e mediante o trabalho de designers que apresentem novidades, com elementos de brasilidade, com qualidade de produção e com a utilização de materiais brasileiros, ou seja, não se pode simplesmente seguir tendências que são ditadas pelos europeus. 
No seu entendimento, espera-se uma moda diferente do Brasil, uma moda que remeta ao clima tropical, mas ressalva que a moda brasileira não fará sucesso no exterior somente pelo fato de ser feita no Brasil, mas sim em função de competência e qualidade em design, da melhoria do processo de qualidade para apresentar uma moda com estilo de vida que o mercado possa entender e aceitar. Pimentel cita ainda que há muitos entraves que atrapalham a internacionalização da moda brasileira.

\section{Entrevistado A2 - André Hidalgo (Casa de Criadores)}

O entrevistado A2 é um agente de apoio chamado André Hidalgo. O entrevistado estudou cinema, linguística e jornalismo, tendo como a última atividade, sua profissão. Trabalha no ramo da moda há 15 anos e é fundador e Diretor da Casa de Criadores, onde, desde 1997 trabalha junto a jovens estilistas, promovendo eventos duas vezes ao ano para lançar novas coleções.

Desde a $1^{\text {a }}$ edição da casa de criadores, o evento foi bem recebido pelo mercado de moda. Os estilistas precisavam de um espaço, assim, quando o mercado percebeu que o evento tinha boa aceitação, foi naturalmente crescendo (na $1^{\mathrm{a}}$ e na $2^{\mathrm{a}}$ edição teve seis participantes, já na $3^{\mathrm{a}}$ teve oito e depois doze) e foi aumentando tanto em número de participantes quanto de patrocinadores. O objetivo principal da Casa de Criadores era o de criar um espaço para maior aproximação entre os estilistas participantes e o mercado da moda brasileira.

Desde seu início, a Casa de Criadores já lançou e projetou designers como Marcelo Sommer, Cavalera, Ronaldo Fraga, Marcelo Quadros, Carlota Joaquina, André Lima, Karlla Girotto, Mário Queiroz, V.Rom, Lorenzo Merlino, Fábia Bercsek, Priscila Darolt, Simone Nunes, Erika Ikezili, Giselle Nasser, Samuel Cirnansck, Rita Wainer, Elisa Chanan, Juliana Jabour, Icarius, Jeziel Moraes, Gêmeas, Walério Araújo, João Pimenta e Gustavo Silvestre, entre várias outras marcas expressivas no contexto da moda nacional. Há uma estimativa de que um terço dos estilistas que participam do SPFW foi lançado pela Casa de Criadores.

A casa de Criadores surgiu no mercado da moda em um momento importante, conforme explica o entrevistado:

A Casa de criadores foi criada no novo boom da moda, foi um boom muito 
consistente, pela $1^{\text {a }}$ vez a moda brasileira começou a se levar a sério e a ser levada a sério de fato, a moda quase que formou um movimento não estético ainda, mas um movimento comercial mesmo, forte de as pessoas terem interesse, o fato de se organizar um calendário da moda brasileira, foi super positivo para essa questão comercial para compradores, o próprio mercado se organizar, se regulamentar, isso realmente deu uma super fortalecida, porque a moda brasileira passou a ter uma série de eventos que o comprador pode ir lá e adquirir, as feiras divulgam a moda brasileira, fez como que a nossa moda passasse a ser levada a sério.

Para Hidalgo a moda brasileira é resultado de elementos que caracterizam o Brasil e está evoluindo para ter um design próprio, respeitando o consumidor global. Para ele a moda praia brasileira se destaca no mercado internacional. Logo, André Hidalgo acredita que a identidade da moda brasileira é constituída por elementos como: a sensualidade (formas e volumes), cores, exuberância, o estilo de vida do brasileiro, criatividade e estampas.

O entrevistado menciona o momento econômico-social que o Brasil vive como elemento impulsionador para a consolidação da imagem do Brasil na moda no contexto internacional. Segundo o ele, o mercado internacional busca um produto de moda com design e com bom preço.

Assim, Hidalgo acredita que a moda brasileira se diferenciará no exterior, de forma marcante, a partir do momento em que designers utilizarem sua criatividade e ousadia com elementos da brasilidade em peças, unindo a isso conceito, qualidade e bom preço. Para o entrevistado, a moda brasileira ainda não se consolidou no mercado internacional, mas cita que as pessoas estão curiosas para saber o que se tem feito no Brasil em temos de moda, mas menciona que alguns estilistas brasileiros ainda copiam modelos europeus.

Hidalgo acredita que o mercado externo é receptivo a moda brasileira e tem expectativa de encontrar um produto diferente de moda feita no Brasil, isso em função da imagem que ainda persiste sobre o país, que está relacionada ao paraíso, à praia, a natureza, ao exótico. Junto a isso, o entrevistado cita que o Brasil é uma economia emergente e que receberá dois grandes eventos nos próximos anos, por isso, o interesse pelo Brasil e seus atributos é cada vez maior por parte de consumidores de outros países. 


\section{Entrevistado A3 - Antônio Haslauer da Costa (AHadvisoring)}

O entrevistado A3 dirige uma empresa de consultoria chamada AHadvisoring, trabalha para empresas no segmento da moda e de cosméticos, prestando serviços de gestão de marcas, imagem e conecta ao Brasil diversas operações. Sua empresa de consultoria opera em diversos negócios que orbitam no eixo moda-aspiracional-cosmética-beleza-publicaçãobranding. Tem como um de seus clientes a loja de departamentos Macy’s nos EUA e foi responsável pela escolha, capacitação e alinhamento das marcas Brasileiras ao mercado americano para o evento Brasil: a magical journey que aconteceu na loja de departamentos de Nova Iorque durante três meses (verão americano de 2012).

Iniciou sua carreira no segmento da moda há vinte e cinco anos. Foi CEO de um grupo de moda baseado em Nova Iorque, em seguida deixou o eixo Nova Iorque - Milão e começou a trabalhar como consultor para o então Grupo Fórum com Tufi Duek, onde encabeçou o processo de internacionalização da marca, que teve início em 1986, ainda em um período, segundo o entrevistado, "muito embriônico da consciência da moda no Brasil". Neste processo, realizou um trabalho de qualificação do portfólio da marca e da imagem da marca e implantou a marca Tufi Duek nos EUA e, a partir dos EUA, inseriu a marca no Canadá, na Europa, na Ásia e no Oriente Médio.

A área de atuação do entrevistado não se restringe ao segmento da moda, ele atua junto a empresas de beleza, de cosméticos. Ele acredita que o executivo de negócios de moda, deve gerir imagem, os atributos aspiracionais, de beleza, o luxo. Assim sendo, o entrevistado acredita que a moda é um segmento que prepara o executivo para atuar em outras áreas que demandem um tipo de gestão fortemente relacionada à experiência e à imagem.

Na opinião de Antônio a moda brasileira é um estilo de vida. Ele cita que o país ainda não desenvolveu uma imagem do país no contexto da moda, mas acredita que o Brasil é um país que tem boa aceitação, por parte do mercado externo, que há muito interesse pelo Brasil em diversas áreas, como: moda, design, cinema, música, culinária e arquitetura, e que há muito potencial na brasilidade que pode e deve ser explorada. Assim, comenta que os designers brasileiros que possuem uma identidade brasileira bem desenvolvida que entendem a realidade do mercado global, são profissionais que tem potencial para inserção em mercados internacionais. 
Para Haslauer, o mercado internacional da moda demanda produtos com tendências atemporais, assim como, exige qualidade, design e constância em termos de visão de produto e qualidade, que possam transmitir um estilo próprio. Segundo ele, o mercado internacional busca no produto de moda brasileira elementos básicos de referencial brasileiro como: cores, vibração, alegria, sensualidade, leveza, estampas que traduzem o estilo de vida do brasileiro.

No entanto, o entrevistado menciona que a identidade da moda brasileira ainda está em processo de desenvolvimento, que envolve o descobrimento e apropriação de elementos brasileiros e a viabilidade financeira dos produtos que ainda são muito caros no exterior.

O entrevistado acredita que o produto de moda brasileiro se diferenciará no mercado internacional a partir do momento em que houver uma consciência, por parte dos agentes da moda brasileira, em desenvolver produtos inovadores. Menciona ainda que a utilização dos atributos de brasilidade na moda representa fonte de vantagem competitiva no mercado internacional, sem apelo à caricatura, com design, sensualidade e utilizando elementos expressivos do Brasil.

No entanto, Haslauer menciona alguns entraves à inserção da moda brasileira no mercado internacional e acredita que a primeira ação a se fazer é uma análise critica com relação aos produtos que estão sendo ofertados pelas marcas brasileiras, pois ainda há resquícios de cópias. Ele recorre à história da moda no Brasil para explicar os motivos pelos quais marcas brasileiras se habituaram a copiar modelos europeus, cita que ainda existem marcas que persistem em reproduzir modelos e isso denigre a identidade que se busca disseminar sobre o produto de moda brasileira.

Haslauer menciona outros entraves à internacionalização da moda brasileira, como o custo Brasil, a penalização fiscal e a falta de senso de precificação de produtos por parte das marcas. Para o entrevistado, a criatividade da moda brasileira é o elemento mais apreciado pelo mercado internacional e deve ser explorada.

Por fim, o entrevistado cita que existe um interesse genuíno, por parte do mercado externo, pelo Brasil em diversas áreas e aponta para a importância da mobilização dos agentes de mercado para que este interesse no Brasil possa se traduzir em negócios. 


\section{Entrevistado A4 - Evilásio Miranda da Costa (ABIT)}

O entrevistado A4, chamado Evilásio Miranda da Costa trabalha no segmento da moda desde 2006. É bacharel em Relações internacionais e pós-graduado em comércio exterior. Sua área de atuação é em moda e design, atualmente trabalha na Abit (há dez meses), onde gerencia a área de moda e design, desenvolvendo trabalhos em capacitação em design de micro e pequenas empresas e, também, desenvolve o projeto promoção internacional, por meio do núcleo de marcas dentro do programa TexBrasil.

O entrevistado sempre trabalhou na área de comércio exterior e promoção internacional. Começou a trabalhar no segmento da moda quando estava na Apex em Brasília no ano de 2006, onde gerenciou os projetos da Abit, os da Abest, os da Abicalçados, os da Assintecal e da CICB (Centro das indústrias de Curtumes do Brasil), todas associações no segmento de moda e realizou este trabalho por três anos.

Em 2009 mudou-se para São Paulo para gerenciar a Abest (Associação Brasileira dos Estilistas), tanto os projetos de internacionalização como as demais ações da entidade, mas principalmente o projeto de internacionalização. Ficou na Abest por pouco mais de dois anos e depois deu início ao seu trabalho atual na Abit.

Na opinião de Miranda o mercado internacional de moda é divido em nichos, sendo que alguns mercados buscam preço, outros um bom produto e outros a exclusividade. Ele acredita que o mercado busca produtos de moda de qualquer país, não exclusivamente do Brasil, mas que tenham identidade, qualidade, com um preço adequado ao que é oferecido, vindo de uma marca que tenha profissionalismo e consistência entre uma coleção e outra. Logo, o entrevistado acredita ser difícil um comprador buscar um produto pelo fato deste ser brasileiro, no seu entendimento o comprador está buscando os mesmos atributos que busca em produtos de qualquer fornecedor do mundo.

Miranda cita que foi realizado um estudo pela Abit, sobre imagem da moda brasileira, em que jornalistas compradores e especialistas internacionais foram entrevistados com o intuito de se entender quais atributos fazem parte da moda brasileira. $\mathrm{O}$ resultado apontou os seguintes atributos: autenticidade, que os brasileiros são vibrantes, diversos e sustentáveis. Já no entendimento do entrevistado, a moda brasileira envolve atributos como cores, estampas, 
formas e volumes e o estilo de vida do brasileiro.

Assim, Miranda cita que o produto de moda brasileira que vende no mercado internacional é o produto que tenha equilíbrio entre qualidade, consistência e preço adequado, que seja colorido, vibrante e descontraído.

Para o entrevistado, a moda brasileira tem uma identidade que está se construindo, pois a história da moda nacional ainda é muito recente, até a abertura do mercado comercial a moda feita no Brasil era referenciada nas coleções europeias. Miranda menciona que na atualidade há um movimento da sociedade brasileira que busca valorizar o Brasil, ou seja, as pessoas começam a valorizar a cultura brasileira, a história do Brasil e a iconografia do país que estão sendo transferidos para a moda. Ele cita que o brasileiro está rejeitando produtos copiados da Europa e, assim, acredita que o Brasil está desenvolvendo uma identidade de moda buscando referencial em sua história, geografia e iconografia.

Para Miranda o mercado internacional valoriza, na moda brasileira, o estilo de vida, a sensualidade, a sensação de relaxamento e descontração. Ele acredita que os atributos da brasilidade podem representar fonte de vantagem competitiva, porém, são elementos que podem ser apropriados por qualquer marca e cita um varejista Francês que utiliza fotos do Rio de Janeiro para fazer sua publicidade e identidade da marca.

Por fim, o entrevistado comenta que uma das principais barreiras à internacionalização da moda feita no Brasil é a mentalidade do empresário brasileiro, pois este pensa em fazer negócios no curto prazo e não entende a importância de realizar um bom trabalho de exportação. Além disto, aponta como entrave a dificuldade de acesso à matéria-prima de boa qualidade.

\section{Entrevistado A5 - Geni Rodio Ribeiro (ABIT e Escola São Paulo)}

A última entrevistada que faz parte dos agentes de apoio chama-se Geni Rodio, que é formada em Publicidade e Propaganda e trabalha no segmento da moda há trinta e cinco anos. A entrevistada começou sua trajetória neste segmento no final dos anos 1970 pela fiação, na Polyenka e permaneceu trabalhando nesta indústria por onze anos. Lá aprendeu sobre fio e têxtil, pois visitava clientes e trabalhava no desenvolvimento de produtos de fios com foco em 
marketing. Nesta época, somente as grandes empresas que tinham poucas pessoas que entendessem minimamente de moda, esta pessoa desenvolvia uma cartela de cores e desenvolvia as estampas.

No começo da década de 80 ela começou a ter contato com as sedas sintéticas e ela menciona que até os dias de hoje a indústria brasileira tem dificuldades para produzir tecidos similares aos que são desenvolvidos fora do Brasil. Durante a época que trabalhou na Polyenka montou um grupo de estudos de cores, de comportamento, de tendências que integrava profissionais de tecelagem, de malharia e dos grandes magazines. A cartela de cores desenvolvida pelo grupo de estudos passou a ter grande importância no varejo, os produtos passaram a ser desenvolvidos com base no trabalho realizado pelo grupo.

Depois foi convidada para trabalhar na maior empresa de tecelagem que era cliente da Polyenka, na área de desenvolvimento de produto têxtil, passando a desenvolver tecidos (não só cores e fios como fazia na Polyenka). Neste momento, as indústrias têxteis começavam a sentir a necessidade de ter alguém no seu quadro de profissionais que entendesse mais de moda para dar uma identidade à coleção.

No final da década de 80, Rodio também trabalhou como consultora, auxiliando na elaboração da grade curricular dos cursos de moda que começavam a ser criados no Brasil. Junto a isso, foi a primeira lojista da Benetton em São Paulo e acabou tendo quatro franquiadas da marca italiana em São Paulo. A oportunidade de trabalhar com lojas a aproximou ao varejo, enriquecendo sua experiência no segmento.

Depois trabalhou na Vicunha (indústria têxtil) e, em 2003 foi trabalhar na Abit para atuar no programa de apoio a exportação, o TexBrasil, que é um programa inteiramente voltado para a internacionalização das empresas brasileiras que queiram participar deste programa de apoio. A sua experiência tanto na Polyenka, quanto na Vicunha e na Benetton foram fundamentais para ela conhecer o mercado internacional, seus atores, assim como passou a entender do comportamento do mercado internacional para desenvolver parcerias. Com isso, quando iniciou o trabalho na Abit, ela sabia das fragilidades da indústria têxtil brasileira, uma indústria caraterizada pela exportação de matérias-primas (fibras de algodão). Assim, Rodio comenta que ajudou a desenvolver um projeto de estruturação e capacitação das empresas que têm interesse em fazer parte do TexBrasil, para que tais empresas consigam atender a 
demanda internacional.

Atualmente trabalha como consultora na Abit, na Abest e coordena e ministra aulas nos cursos de moda da Escola São Paulo.

Para Rodio o mercado, no âmbito nacional e internacional, demanda um produto de moda que seja diferenciado, pois, segundo ela, atualmente vive-se um momento em que há um excesso de oferta de produtos, assim, para uma empresa ter sucesso diante desta conjuntura, deve diferenciar seu produto. Ela aponta que esta estratégia se mostra ainda mais importante se o empresário de moda almeja inserir seu produto entre fronteiras, uma vez que a estrutura industrial têxtil brasileira não permite que se concorra por meio da estratégia de liderança em custos.

Rodio comenta que existem empresas que fazem parte de um grupo da indústria que produz vestuário e outras que desenvolvem a moda. Na primeira, ela menciona que não há um envolvimento do empresário, um comprometimento com o desenvolvimento da moda e, assim, só se reproduz produtos que se destacaram como tendência nos desfiles europeus. Ao passo que o empresário que está comprometido com o desenvolvimento do produto, busca diferenciar-se.

Para Geni Rodio, a diferenciação da empresa começa por meio da criação de uma identidade, o que ela denomina "uma raiz para contar a sua história". O segundo passo para diferenciação é fazer o produto de um jeito brasileiro, com criatividade, que imprima o estilo de vida do brasileiro e que atenda ao desejo do mercado globalizado.

Ela destaca, que junto à criação de uma identidade e da utilização do jeito de ser do brasileiro na criação de uma marca, que também devem ser desenvolvidos no produto, a empresa, para se diferenciar, deve atentar as seguintes características de produto: ser interessante, bonito, confortável, bem feito, com design, qualidade e boa modelagem.

A entrevistada acredita ser fundamental que a empresa tenha o suporte e serviço adequado para atender o cliente. Ela também cita a importância da diferenciação por meio da inovação e da sustentabilidade nos processos da empresa e acredita que esse é um bom momento para as marcas de moda brasileira buscarem a diferenciação por meio da imagem do país de origem. 
Para Rodio a moda brasileira ainda está construindo a sua identidade, ela acredita que esse é um trabalho longo e que demanda histórico, elemento que a moda brasileira ainda não tem, pois a moda nacional é jovem e por isso a sua identidade ainda está em desenvolvimento. Rodio acredita que a moda brasileira é feita de cor, alegria, comportamento, conforto. Assim, os atributos da brasilidade na moda em sua opinião são: cores, estampas, o estilo de vida e as formas e volumes. No entanto, Rodio não gosta de estereotipar, ela menciona que os atributos devem ser utilizados de forma suave, sem exagero para não produzir um produto caricato da moda brasileira.

A entrevistada acredita que o Brasil tem uma característica que nenhum outro país no mundo tem. Característica que se deu em função da história do Brasil de sua colonização e imigração, que resultou na miscigenação cultural entre índios, negros e europeus. Para ela essa mistura gera alegria e entusiasmo que conferem ao povo brasileiro um DNA muito forte, um estilo de vida que deve ser explorado de forma positiva para fazer negócios.

A entrevistada comenta que o Brasil vive um momento econômico e social muito importante, por ser um destino interessante de investimento em função da Copa e das Olimpíadas, por ser um país emergente e por ser interpretado pela mídia internacional como um país interessante, além de ser um destino turístico.

Segundo Rodio, o resultado da inserção da moda brasileira no mercado internacional ainda é pequeno, pois a moda brasileira tem uma história recente e começou a buscar mercado entre fronteiras há pouco tempo de forma profissionalizada. Mas cita duas marcas que estão fazendo um bom trabalho de inserção internacional, a Cecília Prado e a Alessa. Segundo a entrevistada essas marcas têm uma história e estão construindo suas imagens pautadas pelas suas identidades, com autenticidade, persistência e consistência.

A entrevistada acredita que a brasilidade na moda representa uma fonte de vantagem competitiva para competir no mercado internacional de moda, pois o Brasil "exerce um fascínio [...] existe uma simpatia muito grande pelo Brasil”, no entanto, ela menciona que essa não deve ser a única forma de sustentação da oferta.

Por fim, a entrevistada cita alguns entraves à internacionalização da moda brasileira, como a falta de profissionalismo das empresas com relação à prestação de suporte e serviço. Ela 
menciona que serviço de atendimento e entrega de produto realizado por muitas marcas brasileiras é visto com desconfiança, ou seja, os compradores internacionais não se sentem seguros ao comprar coleções brasileiras. A entrevistada acrescenta como entraves: o custo Brasil, o câmbio, a logística deficiente, as plataformas de produção e a falta de mão de obra qualificada e motivada.

\subsubsection{Entrevistas com agentes de demanda}

Dando continuidade a pesquisa, foram entrevistados quatro agentes de demanda. Tais entrevistados e as descrições das entrevistas serão apresentadas a seguir.

\section{Entrevistado A6 - Nic Cox (Garderob)}

O agente demanda, identificado neste estudo como Entrevistado A6, chama-se Nic Cox. Ele é Inglês e atualmente trabalha para um varejista Russo de moda chamado Garderob, cujo escritório central e ponto de vendas fica em Moscou, porém, ele trabalha a partir de Londres.

O entrevistado trabalha no segmento da moda há vinte anos. Durante esses anos trabalhou como stylist (produtor de moda), comprador de moda e jornalista. Também trabalhou algumas vezes para varejistas brasileiros de moda, trazendo roupas de designers internacionais para o Brasil. Para Cox um bom produto de moda tem que seguir tendência, ser usável, deve ter um bom preço e ser bem manufaturado.

A empresa em que trabalha atualmente compra produtos de moda brasileira há quatro anos por meio de show rooms em Nova Iorque e, somente, em 2012 que começou a comprar diretamente das marcas brasileira, por esse motivo que o comprador estava do São Paulo Fashion Week. Cox já veio ao Brasil outras três vezes para assistir desfiles.

O entrevistado disse que a moda brasileira tem boas coleções de primavera e verão, destacando-se a moda praia e lingerie de luxo. No entanto, a moda brasileira não oferece coleções de outono e inverno adaptadas ao clima do hemisfério Norte. Ele menciona que compra moda praia e piscina, mas que os produtos de moda brasileira ainda representam uma 
pequena parte do mix de produtos que a empresa em que ele oferece ao mercado Russo. Cox tem o intuito de aumentar o percentual do produto brasileiro no mix da marca, uma vez que percebe que as pessoas estão interessadas no Brasil e estão procurando produtos brasileiros.

O entrevistado cita que um produto de moda diferenciado deve ser um produto que segue tendência, deve ser usável (ou seja, adaptado ao público local), com bom preço e ser bem manufaturado.

Ele menciona que com o a globalização, o mundo está cada vez menor, por isso, a moda tem que ser adaptada à linguagem global. Ele valoriza a moda brasileira, por isso vem ao Brasil fazer compras, mas comenta que o produto de moda e seu design devem ser de qualidade, independente de sua origem.

A moda brasileira, na opinião do entrevistado, tem uma identidade que está evoluindo e se tornando cada vez mais internacionalizada. Os designers brasileiros estão mostrando seus trabalhos fora do Brasil, sua moda começa a ter uma linguagem global, sem perder as raízes brasileiras. Assim, para o entrevistado, a identidade da moda brasileira envolve mais elementos do que somente matérias primas naturais, texturas, cores e trabalhos feitos à mão.

Logo, Cox menciona como atributos de brasilidade na moda: matérias primas naturais, cores, aplicações e técnicas artesanais e o estilo de vida. Comenta que a moda brasileira, para fazer sucesso no mercado internacional, não pode ser caricata, tão pouco se apoiar somente em trabalhos feito à mão. Para ele o mercado valoriza o estilo de vida do brasileiro que se reflete numa boa moda casual.

No entanto, o entrevistado menciona que o consumidor final, apesar de se interessar pelo Brasil, ainda não tem compreensão sobre a imagem do Brasil na moda, mas valoriza, principalmente pelo estilo de vida.

\section{Entrevistado A7 - Nancy Huam Matute (Empório JLC)}

A segunda agente de demanda entrevistada chama-se Nancy Huam Matute, identificada neste estudo como Entrevistado A7. Matute trabalha em uma empresa de confecção e varejo 
Peruana chamada Empório JLC que está no mercado há mais de quinze anos. O empório JLC comercializa cerca de cento e vinte mil peças por estação em seus dezoito pontos de vendas. A empresa compra produtos de moda Brasileira há dois anos.

A entrevistada é designer, trabalha no segmento da moda há seis anos e começou sua trajetória como estagiária, ainda na faculdade, na mesma empresa que trabalha até hoje. No início sua função era desenhar fichas técnicas. Atualmente é designer na empresa e ajuda a comprar matéria-prima. Nessa função, já veio ao Brasil três vezes, sendo uma para olhar a moda brasileira e as demais para comprar em feiras.

Segundo a entrevistada o Brasil representa a Europa na América do Sul, assim, compradores que não podem ir até a Europa para pesquisar moda, vão ao Brasil, pois sabem que nesse país há boas referências de moda. Ela menciona que os brasileiros trazem as tendências europeias para a América do Sul e adaptam ao público latino.

Para a entrevistada um bom produto de moda deve ter qualidade. Segundo ela, a moda brasileira reflete o estilo de vida do brasileiro, por meio da ousadia, criatividade, sem limites para criação. Ela resume a moda brasileira na seguinte palavra: extravagancia.

Matute menciona que o brasileiro não tem medo de ousar, experimentar novas tendências, desfazer tendências, usar decotes e comprimentos menores para sair na rua usando o que quiser do modo que desejar.

Assim, a entrevistada cita os seguintes atributos da brasilidade: cores, estampas, tecidos, estilo de vida e formas e volumes e acredita que a moda brasileira se diferencia por meio das cores, das estampas, dos tecidos e especialmente na moda praia.

\section{Entrevistado A8 - Andrea Lopez (Saha Modamar)}

A entrevistada A8, é um agente de demanda, chama-se Andrea Lopez, é designer e trabalha na Saha modamar, confecção de moda praia sediada em Bogotá, na Colômbia.

A entrevistada começou sua carreira no segmento da moda na área de pesquisas e marketing 
de moda em uma fábrica e atualmente é designer. A empresa para a qual trabalha atualmente está no mercado há seis anos, distribui suas peças em pontos de vendas em mais de vinte cinco países e compra produtos de moda Brasileira há quatro anos, mas as compras de produtos brasileiros se intensificaram no último ano.

Lopez menciona que o Brasil é uma grande referência para ela e diz que quando desenvolve novos produtos, tem como hábito pesquisar em sites de marcas brasileiras como: Rosa Chá, Água de Coco, Salinas, Cia Marítma, magazines brasileiros, ente outras, para inspirar-se. Assim, ela cita que quando pensa em moda brasileira logo se lembra de moda praia.

Segundo Lopez, o consumidor final ainda não entende os atributos da moda brasileira, mas estilistas internacionais se inspiram no Brasil para desenvolver suas coleções.

Os atributos que a entrevistada considera em um produto de moda são: qualidade, estampa, cores e o preço. Para ela, o produto de moda brasileira apresenta os seguintes elementos diferenciadores: tecidos, confecção, formas e volumes, estampas e cores.

\section{Entrevistado A9 - Renoux Hugues (Sable Chaud)}

O entrevistado A9 é de origem Francesa, seu nome é Renoux Hugues, ele é proprietário de uma loja de moda brasileira em Paris chamada Sable Chaud. Hugues trabalha no segmento da moda desde 2008 e iniciou seu trabalho nesse segmento em função da moda praia brasileira. Isso aconteceu porque ele comprou peças de moda praia para sua esposa e percebeu que era um produto que era demandado na sua cidade, uma vez que a moda praia francesa é, segundo ele, antiga.

A partir da ideia de montar um negócio de moda praia, ele começou a pesquisar empresas de moda praia brasileira por meio de sites de busca e entrou em contato com alguns produtores brasileiros que lhes enviaram amostras. Com as amostras em mãos, Hughes e sua esposa organizaram um desfile privativo em um loft com modelos. Para esse desfile convidaram profissionais que trabalhavam no departamento comercial da varejista Francesa Printemps que foram ao evento e gostaram da moda praia brasileira, assim, convidaram Hughes para fazer o desfile na loja da Printemps e depois ofereceram oito metros quadrados para Hughes 
comercializar as peças de moda praia brasileira durante três meses (temporada de verão) na loja. Durante este período Hughes vendeu mais de Dezoito mil Euros.

No final de Julho de 2008, Hughes não tinha mais peças para comercializar, por isso, foi ao Brasil e fez pedidos a diversos designers brasileiros e em março de 2009 abriu sua loja no bairro de Marais em Paris, para comercializar moda praia brasileira.

Segundo Hughes a moda brasileira ainda não tem uma imagem formada no mercado externo. Para ele há que se explicar o conceito da moda brasileira e ele tenta fazer isso, no seu ponto de vendas, abordando elementos que rementem a ecologia, a sustentabilidade e a forma como o produto é manufaturado. Ele cita que seus clientes têm uma imagem positiva do Brasil, mas que se restringe aos cariocas, a um país de clima tropical, otimista, à vida praiana e de bon vivant.

O entrevistado acredita que a moda brasileira tem uma identidade e discorda de pessoas que dizem que a moda brasileira copia o design europeu. Pelo contrário, ele menciona que já viu marcas europeias se inspirarem em estampas brasileiras para fazer suas coleções de verão.

Hughes entende que o Brasil é um país miscigenado, que é maior do que a Europa, por isso tem diversas culturas misturadas e tal diversidade se reflete na moda por meio de vários conceitos. Assim, a marca que utilizar elementos da cultura brasileira para desenvolver seu conceito deve explicar a nuance da brasilidade na qual se apoia.

O entrevistado menciona que a Brasilidade é um espírito e que esse conceito é conhecido fora do Brasil, no entanto, na moda ainda não se tem uma imagem do Brasil formada, ou seja, o público consumidor final não tem uma imagem consolidada sobre a moda brasileira, compram em sua loja porque gostam da imagem do Brasil, da sua ecologia, do fato de o Brasil não ter inimigos e de ser um país em ascensão.

Assim, Hughes não disse de forma direta o que ele entende por elementos que compõem a brasilidade na moda, mas, por meio dos questionamentos feitos ao longo da entrevista, podese perceber que os atributos de brasilidade na moda para ele são: cores, estampas, tecidos e estilo de vida. 
Durante a entrevista Hughes mencionou algumas deficiências da moda brasileira que vão além do custo da mercadoria, tais como: 1) as marcas brasileiras não desenvolvem coleções de inverno adaptadas ao clima europeu, ou seja, durante as estações de outono e de inverno, o varejista europeu não tem como vender moda brasileira; 2) falta de comprometimento com as entregas, o comprador faz um pedido e não recebe a mercadoria no prazo acordado; 3) elevada rotatividade nas empresas brasileiras, o que dificulta o desenvolvimento de um relacionamento de parceria entre a marca brasileira e o comprador internacional; 4) a qualidade do processo de costura é ruim, pois o trabalho é realizado em facções; 5) custo do transporte para entrega das peças é caro e demorado.

\subsection{Análise dos dados}

A análise iniciou-se com a preparação do material escolhido, ou seja, a transcrição das gravações e a leitura cuidadosa das mesmas, conforme preconizado por Flick (2009). Os textos foram sintetizados, buscando-se eliminar os trechos que não seriam relevantes para responder o problema de pesquisa e as repetições. Os trechos iniciais e finais das entrevistas (apresentações e saudações) também foram excluidos, assim como os elementos utilizados para manter a conversação e os trechos que desviavam dos temas da pesquisa.

A partir da preparação, os trechos foram codificados em eixos de acordo com os principais termos utilizados para alicerçar o estudo que deram origem às dimensões e sub-dimensões, as quais serviram de base para a análise. As dimensões e sub-dimensões estão relacionadas no quadro 12.

Quadro 12 - Dimensões e sub-dimensões da análise de dados

\begin{tabular}{|c|c|}
\hline Dimensão & Sub-dimensão \\
\hline \multirow{3}{*}{$\begin{array}{l}\text { A imagem do país de origem no } \\
\text { contexto da moda brasileira }\end{array}$} & A imagem do país de origem e Brasilidade \\
\hline & Identidade da Moda Brasileira \\
\hline & Atributos de Brasilidade na Moda \\
\hline \multirow{4}{*}{ 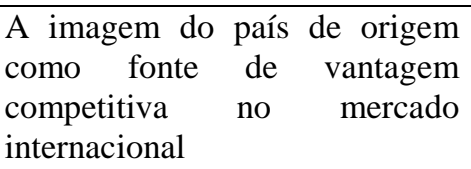 } & A moda brasileira no mercado internacional \\
\hline & A apropriação dos atributos da imagem do país de origem na moda \\
\hline & Formas de diferenciação do produto de moda no mercado internacional \\
\hline & Entraves à inserção da Moda Brasileira no mercado Internacional \\
\hline
\end{tabular}

Para dar início à análise dos dados, considerou-se o discurso de todos os entrevistados com relação a cada sub-dimensão do estudo e confrontou-se as falas com os apontamentos 
estudados na teoria.

\subsubsection{A imagem do país de origem no contexto da moda brasileira}

Para compreender a imagem do Brasil no contexto da moda internacional e se há uma imagem consolidada da moda brasileira no mercado internacional, fez-se necessário compreender o entendimento dos entrevistados sobre as seguintes sub-dimensões: a imagem do país de origem - Brasilidade; identidade da moda brasileira, e os atributos de brasilidade na moda, conforme pode ser observado nos itens seguintes.

\subsubsection{A imagem do país de origem e a brasilidade}

Conforme estudado no capítulo de fundamentação teórica, viu-se que a imagem do país é o resultado da sua geografia, história, música, arte, proclamações, cidadãos famosos entre outras características nacionais (KOTLER; GERTNER, 2002), e que as conotações simbólicas e emocionais do país de origem o transformam em um atributo de imagem, interferindo nas avaliações (GIRALDI et al,, 2011b) e decisões de compra que os consumidores fazem no tocante aos produtos fabricados naquele país (GIRALDI, TORNAVOI, 2004; 2005; GIRALDI et al., 2011a).

De acordo com os achados do estudo de Giraldi et al. (2011b), a imagem do Brasil no exterior, na categoria população, remete a sensualidade e beleza da mulher brasileira, a receptividade, por meio da afetividade e hospitalidade e a cultura, em função da comida e do carnaval. No âmbito da política, o Brasil é visto como um país com corrupção, desigualdade social e violência. No aspecto da natureza, as praias, o clima e as belezas naturais configuram a imagem do Brasil. Quanto à categoria que se referia aos esportes, citaram-se ídolos (como Airton Senna) e o futebol. Por fim, quanto às palavras que remetiam à economia, destacou-se a ascensão e produtos (GIRALDI et al., 2011b).

Autores como Ortiz (2006), Holanda (1971), Freyre (1995, 2009), Martins (2002), Bastide (1980), Lucas (2010), DaMatta (2001), Finestrali e Garrido (2010), Morace (2009) e Sebrae (2002), complementam a discussão sobre a imagem do Brasil por meio do debate realizado na 
sessão 2.3 da fundamentação teórica sobre o conjunto de características da cultura e da identidade brasileira.

A pesquisa empírica admite parte dos achados de Giraldi et al. (2011b) e dos apontamentos dos demais autores. Isso pode ser compreendido por meio da fala de alguns dos entrevistados quando indagados sobre os atributos da Brasilidade e em outros comentários ao longo das entrevistas.

No entendimento de Fernando Pimentel (A1) alegria, otimismo, improviso, pouco planejamento, entusiasmo, flexibilidade, competência em como ultrapassar as adversidades, a biodiversidade, o espírito aberto, o clima tropical e ar livre são características quem compõem a imagem do Brasil. Pimentel acrescenta que o Brasil "é um país rico, diversificado, não é hostilizado, pode ser criticado, mas não é hostilizado, não é um país de guerra, tem oportunidades". Seguindo o mesmo raciocínio, André Hidalgo (A2) aponta a ascensão econômica do país, a exuberância, a ousadia e a natureza como elementos que fazem parte da imagem do Brasil.

Para Geni Rodio (A5) o Brasil desperta interesse no mundo pelo fato de ser um destino para investimentos atrativo, por ser um país emergente e se destacar na mídia internacional. Para ela o Brasil é um país intenso em cor, alegria, comportamento e em conforto. Essa entrevistada caracteriza o Brasil conforme o trecho a seguir:

\begin{abstract}
O Brasil é um país quente, é um país que tem uma simplicidade natural, nós somos de uma origem simples nós somos um país que foi colônia e virou império da noite para o dia, é o único país no mundo que passou por essa experiência, então eu acho que toda essa influência que nós temos da cultura negra, da cultura indígena, da cultura da miscigenação da cultura do negro, com o imigrante com o índio, isso deu uma diferença que os outros países não têm. Os Estados Unidos também tinha índio, também tinha negro, mas não tem essa cultura miscigenada que nós temos, sabe? Então isso nos deu um estilo de vida muito diferente, isso nos deu uma alegria, um entusiasmo, brasileiro é um povo entusiasmado, é alegre. Tem problema, é lógico que tem problema, é gente como em qualquer lugar do mundo [...] Agora nós temos uma característica de algumas coisas que são unânimes no Brasil que é muito difícil de encontrar em outros lugares e isso nos dá um dna muito forte.
\end{abstract}

Geni Rodio (A5) aponta mais dois aspectos importantes que fazem parte da imagem do Brasil, um sobre a imagem de sensualidade transmitida ao mercado internacional e o outro se refere a um exemplo de alegria e simplicidade do povo brasileiro. Ela comenta que "o Brasil se encarregou durante cem anos de vender uma imagem sensualizada da mulher brasileira, 
tudo que se mostrou do Brasil lá fora é de uma imagem sempre de um paraíso nu [...] nós ainda somos vistos como um dos grandes destinos de turismo sexual". Por outro lado, mostrando os contrastes do Brasil, a entrevistada cita a apresentação do Gari sambando na cerimônia de encerramento das Olimpíadas de Londres, que na opinião dela encantou o mundo, para exemplificar a alegria, a musicalidade, a descontração, a simplicidade e a simpatia do povo brasileiro.

Geni (A5) também cita a imagem do Brasil com relação à prestação de serviços. Ela menciona que os brasileiros passam desconfiança "uma imagem de quem não conta a verdade, de quem deixa tudo para a última hora, de quem não dá retorno, infelizmente nós temos essa imagem". Pode-se compreender que essa imagem do brasileiro está relacionada ao apontamento de Caldas (2006) sobre o jeitinho de ser do brasileiro, da prática social que visa encontrar um modo de contornar regras.

Na opinião de Antonio Haslauer da Costa (A3) "o Brasil tem uma aceitação em geral muito grande, seja para a moda, para o design, para o cinema [...] quando você pensa em Brasil vai pensar em: cores, vibração, alegria e sensualidade”.

Para Evilásio Miranda (A4) a sociedade brasileira está passando por um movimento de valorização de sua cultura, passando a observar e usufruir de sua história, de sua iconografia e destaca que marcas estão enaltecendo o fato de serem de origem brasileira em sua comunicação, tentando resgatar o espírito brasileiro. O processo de valorização da cultura nacional mencionado por Miranda representa o início do fortalecimento da imagem do Brasil no exterior, pois, conforme destacado pelo estudo do Sebrae (2002), a imagem do Brasil no exterior somente será valorizada a partir do momento em que o país se perceber de modo positivo, identificando o valor daquilo que é característica própria de seu povo.

Os entrevistados Cox (A6) e Lopez (A8), mencionam que o momento é propício para o Brasil, pois o mundo está interessado em conhecer mais o país e os produtos ofertados pelo Brasil. Eles citam que o povo brasileiro tem um estilo de vida descontraído, alegre e simples que está começando a encantar o mundo, por isso, as pessoas estão curiosas para entender a cultura brasileira e como essa pode ser transposta para produtos. Já para a entrevistada Matute (A7) o Brasil é um país extravagante, ousado, sem limites e representa uma grande economia na América do Sul. 
Segundo o agente de demanda Renoux Hughes (A9), os clientes que compram moda brasileira em sua loja em Paris têm uma imagem do país relacionada ao estilo de vida praiano e boêmio dos cariocas. Ele menciona que:

Todo mundo pensa que o Brasil é engraçado, um país quente, otimista, essa é a imagem positiva, mas a negativa é que com essa imagem é difícil vender algo muito caro do Brasil, porque não esperamos este tipo de produto.

No entanto, o entrevistado A9 aponta que a imagem do Brasil está se tornando mais forte no aspecto econômico e que os brasileiros não são nacionalistas, mas têm orgulho de serem brasileiros pela sua música, sua cultura, pelo relacionamento entre as pessoas. Ele diz "vocês têm o mesmo espírito que os africanos de viver em comunidade. Por isso que todo mundo gosta de estar no Brasil, isso é uma vantagem, e a gente adora ir ao Brasil que tem um clima muito amistoso".

A fala de Hughes (A9) vai ao encontro dos apontamentos de Freyre (2009), de que a brasilidade é um modo característico e específico de ser do povo brasileiro, resultado de sua história e miscigenação social e cultural.

Importante destacar que a maioria dos entrevistados mencionou que o Brasil vive um momento econômico e social importante, pois além de ser um destino turístico muito procurado, é uma economia emergente em ascensão, é destino de investimentos externos e receberá dois grandes eventos de repercussão mundial nos próximos anos (Copa de 2014 e das Olimpíadas de 2016). Por essas características o país desperta interesse por parte de consumidores. De acordo com Antonio Haslauer da Costa (A3):

Há um interesse genuíno pelo Brasil em todas as áreas, moda, comida, life style, existe um interesse generalizado no Brasil é um momento que já está em andamento esse interesse, e é preciso que o Brasil se mobilize rapidamente para que isso possa se traduzir em negócios.

Logo, entende-se que esse momento mostra-se oportuno para realizar ações pontuais para o fortalecimento da imagem do Brasil, assim, conforme menciona DaMatta (2001), o brasileiro deve explorar sua capacidade de sintetizar, relacionar e conciliar, para criar zonas e valores ligados à esperança, à alegria e ao futuro, no sentido de utilizá-las nas diversas esferas da vida (cultura, política, religião, economia e relações interpessoais). 
A partir das falas dos entrevistados observaram-se os principais componentes da imagem do Brasil no contexto deste estudo. O quadro 13 reúne os apontamentos encontrados na revisão da literatura que também foram identificados na pesquisa de campo.

\section{Quadro 13 - Elementos da Imagem do País de Origem}

\begin{tabular}{|c|c|}
\hline $\begin{array}{c}\text { A imagem do Brasil de acordo com a } \\
\text { fundamentação teórica }\end{array}$ & Entrevistados que mencionaram tais elementos \\
\hline $\begin{array}{l}\text { Sensualidade e beleza da mulher brasileira (GIRALDI } \\
\text { et al., 2011b); a sensualidade dos corpos (MORACE, } \\
\text { 2009) }\end{array}$ & $\begin{array}{l}\text { André Hidalgo (A2); Antonio Haslauer da Costa } \\
\text { (A3); Geni Rodio Ribeiro (A5); Nancy Huam Matute } \\
\text { (A7); Andrea Lopez (A8); Renoux Hughes (A9). }\end{array}$ \\
\hline $\begin{array}{l}\text { Afetividade e hospitalidade (GIRALDI } \text { et al., 2011b); } \\
\text { solidariedade e índole relacional (SEBRAE, 2002) }\end{array}$ & $\begin{array}{l}\text { Fernando Pimentel (A1); Geni Rodio Ribeiro (A5); } \\
\text { Nic Cox (A6); Renoux Hughes (A9). }\end{array}$ \\
\hline Cultura, comida e carnaval (GIRALDI et al., 2011b) & $\begin{array}{l}\text { Fernando Pimentel (A1); Antonio Haslauer da Costa } \\
\text { (A3); Renoux Hughes (A9). }\end{array}$ \\
\hline Desigualdade social (GIRALDI et al., 2011b). & Geni Rodio Ribeiro (A5); Renoux Hughes (A9). \\
\hline $\begin{array}{l}\text { Natureza, praia, clima e belezas naturais (GIRALDI et } \\
\text { al., 2011b); (SEBRAE, 2002) }\end{array}$ & $\begin{array}{l}\text { Fernando Pimentel (A1); André Hidalgo (A2); } \\
\text { Geni Rodio Ribeiro (A5); Nic Cox (A6); Nancy } \\
\text { Huam Matute (A7); Andrea Lopez (A8); Renoux } \\
\text { Hughes (A9). }\end{array}$ \\
\hline $\begin{array}{l}\text { Ascensão econômica e produtos (GIRALDI et al., } \\
\text { 2011b) }\end{array}$ & $\begin{array}{l}\text { Fernando Pimentel (A1); André Hidalgo (A2); } \\
\text { Antonio Haslauer da Costa (A3); Evilásio Miranda da } \\
\text { Costa (A4); Geni Rodio Ribeiro (A5); Nic Cox (A6); } \\
\text { Nancy Huam Matute (A7); Renoux Hughes (A9). }\end{array}$ \\
\hline $\begin{array}{l}\text { Vasta gama de manifestações culturais (FINESTRALI; } \\
\text { GARRIDO, 2010); (SEBRAE, 2002). }\end{array}$ & $\begin{array}{l}\text { Fernando Pimentel (A1); Antonio Haslauer da Costa } \\
\text { (A3); Geni Rodio Ribeiro (A5). }\end{array}$ \\
\hline $\begin{array}{l}\text { Miscigenação de raças (FREYRE, 1995; 2009), } \\
\text { pluralidade do Brasil (BASTIDE, 1980), mito das três } \\
\text { raças (ORTIZ, 2006); A identidade Cultural: } \\
\text { Multicultural; multirracial; miscigenação } \\
\text { benéfica;“inespecificidade" (SEBRAE, 2002). }\end{array}$ & $\begin{array}{l}\text { Fernando Pimentel (A1); André Hidalgo (A2); } \\
\text { Antonio Haslauer da Costa (A3); Geni Rodio Ribeiro } \\
\text { (A5); Renoux Hughes (A9). }\end{array}$ \\
\hline $\begin{array}{l}\text { Valores: alegria de viver; espontaneidade nos } \\
\text { relacionamentos humanos; a simplicidade no } \\
\text { cotidiano; o acesso a uma experiência que proporciona } \\
\text { felicidade para todos (carnaval); neutralidade dos } \\
\text { produtos (frescor no consumo); a riqueza e a variedade } \\
\text { das cores; os sorrisos e a naturalidade do ambiente e } \\
\text { das pessoas (MORACE, 2009). }\end{array}$ & $\begin{array}{l}\text { Fernando Pimentel (A1); André Hidalgo (A2); } \\
\text { Antonio Haslauer da Costa (A3); Evilásio Miranda da } \\
\text { Costa (A4); Geni Rodio Ribeiro (A5); Nic Cox (A6); } \\
\text { Renoux Hughes (A9). }\end{array}$ \\
\hline Adaptabilidade e abertura ao novo (SEBRAE, 2002). & $\begin{array}{l}\text { Fernando Pimentel (A1); André Hidalgo (A2); } \\
\text { Geni Rodio Ribeiro (A5). }\end{array}$ \\
\hline $\begin{array}{l}\text { O problema da especificidade: Dificuldade em } \\
\text { configurar uma imagem unitária do Brasil, em função } \\
\text { de elementos que contribuem para uma imagem } \\
\text { abrangente do Brasil, por meio dos traços - } \\
\text { geográficos, culturais e sociais - que são fortemente } \\
\text { ligados a realidades locais de caráter específico } \\
\text { (SEBRAE, 2002) }\end{array}$ & Geni Rodio Ribeiro (A5); Renoux Hughes (A9) \\
\hline $\begin{array}{l}\text { O prestígio das expressões artísticas: na literatura na } \\
\text { poesia, no cinema, na arquitetura, nas instalações, na } \\
\text { música popular e na pintura (SEBRAE, 2002). }\end{array}$ & $\begin{array}{l}\text { Fernando Pimentel (A1); Antonio Haslauer da Costa } \\
\text { (A3); Evilásio Miranda da Costa (A4); Geni Rodio } \\
\text { Ribeiro (A5); Renoux Hughes (A9). }\end{array}$ \\
\hline $\begin{array}{l}\text { A ambiguidade, que pode ser exemplificada por meio } \\
\text { do jeitinho brasileiro - prática social que visa } \\
\text { encontrar um modo de contornar regras (CALDAS, } \\
\text { 2006). }\end{array}$ & Geni Rodio Ribeiro (A5). \\
\hline
\end{tabular}




\subsubsection{A identidade da moda brasileira}

Conforme observado na fundamentação teórica, autores como Castilho e Garcia (2001) apontam que frequentemente levantam-se questionamentos sobre a real existência da moda brasileira, cujo resgate de suas origens parece ser tão frágil. De acordo com a literatura, a moda brasileira começou a configurar sua identidade na década de 1920, momento em que as indústrias têxteis nacionais começaram a nivelar sua capacidade de produção de tecidos às concorrentes europeias e às americanas, ou seja, estavam aptas a produzir bens equivalentes com preço competitivo (NEIRA, 2008; BONADIO, GUIMARÃES, 2010).

No entanto, a identidade da moda brasileira não se desenvolveu de forma expressiva até o final da década de 1980, isso em função da proteção de mercado e da valorização do produto internacional (AVELAR, 2009), assim, a moda nacional era caracterizada pela reprodução, adaptada ao clima tropical, de produtos lançados em desfiles europeus.

Com a abertura do mercado, no governo do então Presidente Fernando Collor de Mello, as marcas e estilistas viram-se obrigados a diferenciar suas ofertas para sobreviverem no mercado nacional e explorarem novos mercados (MESSIAS, 2009). Entende-se que foi a partir dessa necessidade, junto à criação de cursos de moda, que a cultura de criação e desenvolvimento de produtos de moda, assim como a identidade da moda brasileira, começaram a ser delineadas de forma expressiva pelas marcas e estilistas brasileiros (BRAGA, 2006; COSTA, 2011).

Logo, a partir da teoria, entende-se que a identidade da moda brasileira é recente, ou seja, começou a se configurar a partir do final dos anos 1980. As entrevistas com os agentes de mercado da moda confirmam os apontamentos encontrados na literatura. Tais ratificações podem ser observadas a partir dos discursos dos entrevistados quando foram incitados sobre a existência da identidade da moda brasileira.

De acordo com a entrevistada Geni Rodio Ribeiro (A5) a moda brasileira é jovem, pois tem um histórico recente e menciona que, por isso, a identidade da moda brasileira está em construção. O entrevistado Antônio Haslauer da Costa (A3) corrobora com a opinião de Geni, afirmando que "o Brasil ainda não desenvolveu uma linguagem muito clara do que que é a moda brasileira no sentido moda pela moda [...] está em processo de desenvolvimento de sua 
identidade, de descobrimento de identidade”. Seguindo a mesma linha de raciocínio, André Hidalgo (A2) cita que "a moda brasileira é o conjunto de coisas que caracterizam a moda Brasil, eu acho que em todas elas a gente ainda tá caminhando, mas eu acho que tá caminhando para ter um design próprio".

No entendimento de Nic Cox (entrevistado A6) a moda brasileira tem uma identidade sim, pois é desenvolvida e manufaturada no Brasil. No entanto, o entrevistado menciona que a moda brasileira tem uma identidade que está evoluindo ao mesmo tempo em que a moda brasileira está se tornando mais internacionalizada.

Já na opinião da entrevistada Nancy Matute (A7), a moda brasileira tem uma identidade que ainda deriva das tendências lançadas na Europa. Ela menciona que "na América do Sul, o Brasil é como se fosse a Europa". Ela acredita que a moda brasileira traz boas referências de moda da Europa e adapta para o público latino em termos de cores, estampas e formas.

O entrevistado Fernando Pimentel (A1), assim como Evilásio Miranda (A4), se aprofundaram quando foram indagados sobre a identidade da moda brasileira, conforme pode ser observado nos trechos a seguir:

Entrevistado Fernando Pimentel (A1):

A moda brasileira vai ganhando identidade, não pode dizer que ela tem uma identidade plenamente consolidada e nem que ela não tem uma identidade. $\mathrm{O}$ mundo se auto-alimenta (Europa está aqui farejando algo que ele precisa levar de fresh para lá, os daqui estão vendo o que a cultura Europeia a tradição o design europeu de qualidade), o mundo está neste processo de intercambiar ideias e propostas e a moda brasileira, que durante muitos anos foi taxada de uma moda copista, vai ganhando uma dinâmica própria, o próprio país ao melhorar a sua capacidade de consumo e referencia pessoal, começa acreditar mais em si e começa a ousar mais a partir dos seus valores. É bobagem dizer que o Brasil faz uma moda que ninguém conhece, todo mundo está vendo a moda brasileira com o open innovation e os estilistas que antes ditavam o que ia ser usado hoje eles absorvem e retransaformam aquilo que eles estão vendo nas ruas porque a moda mudou muito [...] a moda brasileira caminha para obter uma identidade, vai passar por aquilo que nós somos, e o que nós somos: um país diverso com muitas manifestações culturais, que tem esse espírito mais extrovertido, que tem uma vida ao ar livre como algo quase que permanente porque é um país tropical, ensolarado, com praia e tudo isso se traduz e tem uma linguagem também metropolitana, cosmopolita, esse amalgama vai evoluir.

Entrevistado Evilásio Miranda da Costa (A4):

Ela tem uma identidade que está se construindo, na verdade a moda brasileira é muito jovem e sempre foi muito referenciada pelo o que vinha de fora. Hoje como a 
gente tá valorizando mais o Brasil e o fato de sermos brasileiros e termos uma cultura, uma história própria e uma iconografia própria isso também tá sendo transferido para a moda, tanto que cada vez mais você vê marcas se identificando como 'a sou uma marca brasileira, quero resgatar esse espírito brasileiro' e as pessoas valorizando essas coisas e rejeitando a cópia e, a gente tem uma identidade que tá se desenvolvendo a partir de diversas coisas, porque, como a gente tá num momento que o mundo, diversos sistemas de moda já desenvolveram a sua identidade, a gente sabe mais ou menos como buscar, então parte até de uns clichês, a Itália tem manufatura, a França tem o luxo, o Japão tem o minimalismo, o que que o Brasil tem? Então já tem uma tentativa de responder a essa pergunta e de traçar uma trajetória mais científica de construir o que que é a moda Brasileira.

De acordo com o entrevistado Renoux Hughes (A9), a moda brasileira tem sim uma identidade. Ele menciona "eu sempre me surpreendo, porque designers sempre dizem que o problema é que os estilistas brasileiros copiam o design da Europa. No meu ponto de vista isso não é verdade porque tudo o que eu vi não é cópia”. Ele cita que uma rede varejista de moda europeia copiou um modelo de uma marca brasileira conhecida pelas suas estampas. Assim, para ele é incorreto afirmar que a moda brasileira segue a moda europeia. No entanto, Hughes acredita que mais importante que identidade é o conceito de moda e, segundo ele a moda brasileira tem muitos conceitos, mas tem uma identidade universal, pois é feita por um povo miscigenado (Italianos, Judeus, Negros, Japoneses).

A partir do exposto, observa-se que a identidade da moda brasileira está em processo de construção, confirmando os apontamentos verificados na literatura. Para entender como está sendo construída a imagem do país de origem na moda, buscou-se compreender, empiricamente, os atributos que compõem a imagem do Brasil no contexto da moda, ou seja, os atributos da brasilidade na moda, elementos que fazem parte da construção da identidade da moda nacional. Esta sub-dimensão será analisada no item seguinte.

\subsubsection{Atributos de Brasilidade na Moda}

Uma das questões de pesquisa da fase empírica buscava responder quais atributos que compõem a imagem do país de origem no segmento da moda brasileira. Assim, os entrevistados foram questionados sobre seu entendimento com relação à brasilidade e como a imagem do país de origem se reflete na moda.

Observou-se, a partir da revisão da literatura e com base nos apontamentos de autores como 
Feghali (2004), Lucas (2010), Avelar (2009), Neira (2008), Leitão (2009), Silveira et al. (2009), Freyre (2009), Morace (2009), Castilho e Garcia (2001), Braga (2010), Rybalowski (2008), Aguiar e Caldas (2006), Centeno (2010), Dener (in DÓRIA, 1998), Chataignier (2006), Bonadio e Guimarães (2010) e Apex (2012), que os principais atributos de brasilidade na moda são: estilos de vida, representações do Brasil e símbolos nacionais, cores, matérias-primas naturais, aplicações de técnicas artesanais, tecidos, estampa, formas e volumes.

Logo, em campo, verificou-se que dentre os oito atributos identificados na literatura, todos foram mencionados, mas somente quatro foram apontamos com maior frequência e nenhum novo atributo foi citado pelos entrevistados. Os atributos que foram mais citados são: cores, estampas, formas e volumes e o estilo de vida. $\mathrm{O}$ atributo representações do Brasil e símbolos nacionais também foi mencionado, mas com menor frequência e, especificamente para a moda praia, mencionou-se o atributo tecidos. Tais achados podem ser confirmados por meio das falas dos entrevistados.

O entrevistado Fernando Pimentel (A1) mencionou os atributos: cores, estampas, representações de símbolos nacionais e o estilo de vida. Tais apontamentos podem ser interpretados por meio do seguinte trecho:

\begin{abstract}
A brasilidade na moda deve respeitar as características regionais, é uma moda mais clara, transparente, mais colorida, que representa um pouco de tudo não é o preto básico, o cinza básico, (Europa está começando a usar e abusar de cores para enfrentar o ambiente de crise) Brasil explora o alto astral, e tem a característica da estampa que é muito bem utilizada, do xadrezes, é influenciada pelas novelas, pela música, pelas manifestações artísticas que tem uma representatividade muito grande no processo de identidade nacional.
\end{abstract}

Já André Hidalgo (A2) mencionou cinco atributos de brasilidade na moda: cores, representações e símbolos nacionais, estampas, formas e volumes e o estilo de vida do brasileiro. O seguinte trecho confirma os apontamentos do entrevistado A3:

A brasilidade é essa coisa de ser sexy, de ser colorida, exuberante, de ter um quesinho tropical, que remete a essa coisa tropical, e há movimentos culturais que remetam a isso também como a própria tropicália, se você ver tem alguns elementos que são recorrentes na moda brasileira, eu quando penso em moda brasileira eu lembro de uma coisa colorida, de estampas, estampas de aves de tucanos, essa coisa que realmente é nossa [...] Tem essa coisa da exuberância, do sensual, as roupas estão sempre meio abertas, o colo a mostra, o comprimento, ou uma abertura na latera [...] A gente tem uma vocação, até pelo clima, pelas condições climáticas de ser exuberante, de usar aquela coisa leve, que muito tempo atrás achava-se que isso era limitante. 
Os entrevistados Antonio Haslauer da Costa (A3) e Evilásio Miranda da Costa (A4) fizeram menção a quatro atributos: o estilo de vida, formas e volumes, cores e estampas como atributos de brasilidade na moda. Antonio Haslauer da Costa (A3) destaca que os estúdios de estampa brasileiros são superiores aos Europeus e aos Americanos.

Outro aspecto importante mencionado por Antonio Haslauer da Costa (A3) é o de que, no seu entendimento, o principal atributo da brasilidade é o estilo de vida. Para Antonio, por meio da correta apropriação do estilo de vida do brasileiro que uma marca poderá ofertar elementos tangíveis e intangíveis em seus produtos. Para ele o estilo de vida do brasileiro é uma:

Mistura de praia, tropical, design, arquitetura, sofisticação. Todos componentes juntos, criam o lifestyle do Brasil, não é só a estampa de folhas e a miscigenação do Brasil. O que é importante no consumo é a experiência, tem que ter uma narrativa, tem que ter um conteúdo e o Brasil é muito rico disso e quando você apresenta uma proposta do Brasil nesse contexto é uma proposta muito contundente, muito poderosa.

Para Geni Rodio Ribeiro (A5) a brasilidade na moda é traduzida por meio das cores, estilo de vida (alegria e comportamento), pelas formas e volumes (sensualidade e conforto) e estampas. Ela cita o exemplo da Farm. Tais atributos podem ser identificados no seguinte trecho:

Na moda a brasilidade se reflete por meio da apropriação dessas coisas, dessa
alegria, dessa simpatia, desse colorido, desse jeito de ser e começar, minimamente, a
ter, por exemplo, o que que a Farm fez? A Farm é uma moda jovem, uma moda que
vende um estilo híper carioca de ser (que é bem diferente do paulista), é um jeito
que todo mundo gosta. Esse jeito de ser é uma força da moda brasileira. E a Farm
montou a sua loja conceito, a sua flagship em São Paulo, na Vila Madalena e teve a
coragem de colocar pagode no sábado de manhã com caldinho de feijão, e isso é se
apropriar do que é nosso. [...]. Não precisa por pagode e um monte de gente
sambando na passarela, mas você pode por um mix de cores, você pode criar
emoções através da iconografia e das forças que a gente tem. É um conjunto de
coisas. Para a entrevistada Nancy Huam Matute (A7) a moda brasileira é "extravagante, com atitude, sem limites, em que não há tabus. O brasileiro faz a própria moda, o brasileiro não tem receio de se vestir como deseja". Assim, no entendimento de Matute (A7) e de Lopez (A8) os atributos de brasilidade na moda são representados por: formas e volumes, tecidos, cores e estampas. Ambas mencionam que a moda praia brasileira é uma referência para elas.

Para o entrevistado Renoux Hughes (A9), a imagem do Brasil na moda ainda não é compreendida no mercado internacional, ou seja, os consumidores finais ainda não têm um conceito formado sobre a moda brasileira. Ele diz que não é simples compreender a moda brasileira uma vez que: 
O Brasil tem o tamanho da Europa inteira, então você tem que considerar que na mesma semana de moda você tem que apresentar diversos "países" (belgas, dinamarqueses, portugueses, franceses....) gaúcho de Porto Alegre, o do Amazonas de Manaus, são culturas, histórias completamente diferentes, e o Brasil é tão grande, diferente, isso reflete na moda e por isso que é interessante. Você tem um grande mix de cultura, um grande mix de design de moda, mas é interessante porque tudo isso está dentro de uma cultura principal. Os brasileiros tem uma energia boa, são especiais, eles tem uma identidade real.

O entendimento de Renoux Hughes (A2) fortalece os apontamentos de Lucas (2010), autor que acredita que a moda no Brasil é um desfile de mestiçagem. Mas, mesmo diante da complexidade em interpretar a moda brasileira, Hughes (A9) comenta que a brasilidade se reflete na moda por meio do: estilo de vida do brasileiro, das estampas - que segundo ele são muito criativas, pelas cores e por representações do Brasil e símbolos nacionais. Ele acrescenta que na moda praia o tecido também se destaca e que o atributo formas e volumes é o mais procurado pelas suas clientes.

No entendimento do entrevistado Nic Cox (A6) a brasilidade na moda é representada por trabalhos feitos a mão, matérias primas naturais, cores, estampas e pelo estilo de vida do brasileiro que, para ele, é um estilo casual. No entanto, o entrevistado menciona que a moda brasileira não se restringe somente a utilização destes atributos, ele acredita que o design dos estilistas brasileiros é criativo e deve ser adaptado ao que o consumidor global demanda. Assim, ele pondera que os produtos brasileiros de moda não podem ser caricatos, ou seja, que a apropriação dos atributos da brasilidade na moda deve ser feita de uma forma não exagerada e que não deixe o produto com muitas informações.

É importante destacar que outros entrevistados também fizeram menção à forma como utilizar a brasilidade na moda para não tornar o produto caricato. Rodio (A5) cita que não se pode estereotipar a identidade brasileira na moda, ela acredita que a apropriação da brasilidade deve ser feita, no entanto não de modo caricato, mas sim de uma forma discreta que transmita uma mensagem do Brasil sem exagero, sem ser explicitado. Por meio do seguinte trecho a entrevistada expressa seu ponto de vista sobre a brasilidade na moda:

Tudo faz parte eu acho dessa autenticidade, primeiro que nós temos um universo de inspiração que é absurdo, e ele não precisa ser explícito, porque fazer uma inspiração brasileira em cima de palmeiras e tucanos acho que não precisa né. São nuances geometria, sabe você tem um monte de coisas para trabalhar o que você quiser, dentro desse universo de cores e de inspiração e necessariamente você não precisa só trabalhar com isso, você pode trabalhar isso aliado a outras fontes de inspiração que você queira de uma viagem que você fez ao Nepal, porque a moda tem essa liberdade. 
Fernando Pimentel (A1) também segue o raciocínio de Geni (A5), ao citar que não se deve utilizar as inspirações de forma explícita, conforme pode ser observado no trecho a seguir “descobre-se também as nossas manifestações culturais como um fermento, ingrediente de criação, não é para sair fantasiado de cangaceiro, mas elementos desta cultura podem fazer parte de pitadas das roupas que são desenvolvidas".

Diante dos apontamentos dos entrevistados, percebe-se que existem quatro atributos da brasilidade na moda que são mais reconhecidos, pois foram apontados por mais entrevistados, que são: cores, estampas, formas e volumes e o estilo de vida, conforme pode ser observado no quadro 14.

Quadro 14 - Atributos de Brasilidade na Moda na ótica dos entrevistados

\begin{tabular}{|c|c|c|c|c|c|c|c|c|c|c|}
\hline $\begin{array}{ll}\text { Atributo } & \text { Entrevistado } \\
\end{array}$ & A1 & A2 & $\mathbf{A 3}$ & A4 & A5 & A6 & A7 & A8 & A9 & Total \\
\hline Estilo de vida & $\mathrm{X}$ & $\mathrm{X}$ & $\mathrm{X}$ & $\mathrm{X}$ & $\mathrm{X}$ & $\mathrm{X}$ & & & $\mathrm{X}$ & 7 \\
\hline $\begin{array}{l}\text { Representações do } \\
\text { símbolos nacionais }\end{array}$ & $\mathrm{X}$ & $\mathrm{X}$ & & & & & & & $\mathrm{X}$ & 3 \\
\hline Cores & $\mathrm{X}$ & $\mathrm{X}$ & $\mathrm{X}$ & $\mathrm{X}$ & $\mathrm{X}$ & $\mathrm{X}$ & $\mathrm{X}$ & $\mathrm{X}$ & $\mathrm{X}$ & 9 \\
\hline Matérias primas naturais & & & & & & $\mathrm{X}$ & & & & 1 \\
\hline Aplicações e técnicas artesanais & & & & & & $\mathrm{X}$ & & & & 1 \\
\hline Tecidos & & & & & & & $\mathrm{X}$ & $\mathrm{X}$ & $\mathrm{X}$ & 3 \\
\hline Estampa & $\mathrm{X}$ & $\mathrm{X}$ & $\mathrm{X}$ & $\mathrm{X}$ & $\mathrm{X}$ & $\mathrm{X}$ & $\mathrm{X}$ & $\mathrm{X}$ & $\mathrm{X}$ & 9 \\
\hline Formas e volumes & & $\mathrm{X}$ & $\mathrm{X}$ & $\mathrm{X}$ & $\mathrm{X}$ & & $\mathrm{X}$ & $\mathrm{X}$ & $\mathrm{X}$ & 7 \\
\hline $\begin{array}{l}\text { Total de atributos mencionados } \\
\text { por cada entrevistado }\end{array}$ & 4 & 5 & 4 & 4 & 4 & 5 & 4 & 4 & 6 & \\
\hline
\end{tabular}

No entanto, os entrevistados sugerem que a forma como tais atributos devem ser apropriados em produtos e na identidade da marca de moda são essenciais para que a imagem do produto de moda brasileiro não seja caricata. Fernando Pimentel (A1) refere-se à forma como se deve se apropriar da brasilidade como "essa pitada mais bacana de Brasil". Nesse sentido, Antonio Haslauer da Costa (A3) comenta que a empresa que busca levar sua moda para o mercado internacional deve ser muito sábia para saber escolher os componentes da brasilidade que atendam a expectativa do mercado para não ofertar um produto com apelo de caricatura.

Assim, observou-se que os atributos de brasilidade na moda encontrados na literatura foram confirmados pelo estudo de campo. Porém, há um achado da pesquisa empírica que merece especial destaque, pois não foi identificado na revisão da literatura. Esse refere-se ao modo como os entrevistados sugerem que os atributos da brasilidade na moda devem ser explorados pelas marcas de moda e estilistas, conforme explicado por meio das falas dos entrevistados. 


\subsubsection{A imagem do país de origem como fonte de vantagem competitiva}

Para compreender se a imagem do país de origem, no contexto da moda, representa fonte de vantagem competitiva no mercado internacional, os entrevistados foram indagados sobre alguns aspectos da moda brasileira, sobre as formas de diferenciação de produtos de moda e depois foram perguntados, de forma direta, se acreditavam na imagem do país de origem como fonte de vantagem competitiva. Por isso, essa dimensão foi divida em outras subdimensões que serão analisadas a seguir.

Antes, porém, faz-se necessário destacar o apontamento de um dos entrevistados com relação à forma de obtenção de vantagem competitiva que as marcas de moda devem considerar para competir no mercado internacional. A entrevistada Geni Rodio (A5), em seu discurso, menciona as formas de obtenção de vantagem competitiva, sendo via fonte interna, por meio da estratégia de liderança de custos, ou externa à organização, por meio da diferenciação da oferta - conforme apontado por autores como Lambin (2000), Barney (1991) Wen-cheng et al. (2011) e Porter (1989).

Segundo Geni Rodio (A5) o mercado tem excesso de oferta de produtos de moda, ela menciona "overdose de oferta de produtos de moda em qualquer lugar". Assim, para ela, uma empresa que quer concorrer no mercado internacional precisa distinguir sua oferta, pois o Brasil não tem estrutura para concorrer por preço. No trecho seguinte, compreende-se que a entrevistada acredita que a estratégica de posicionamento que as marcas de moda brasileiras devem adotar para competir no mercado externo deve ser por meio da diferenciação, ou seja, que a fonte de vantagem competitiva a ser explorada neste segmento é a externa:

Se não existe falta eu tenho que fazer de alguma forma diferente se eu não fizer, concorrer por concorrer, eu vou ter que concorrer com preço e preço não é o nosso grande diferencial. Essa bandeira do preço a gente não tem, a gente simplesmente não vai ter, esse não é o nosso negócio.

Seguindo o mesmo raciocínio de Geni (A5), André Hidalgo (A2) e menciona "eu acho que o design que vai ser o grande diferencial da moda brasileira, porque preço não vai ser".

As falas da entrevista A5 e do entrevistado A2 confirmam os apontamentos encontrados na literatura de que empresas brasileiras estão buscando implementar estratégias com foco na 
comercialização de produtos de moda com maior valor agregado e na valorização de suas marcas para transações entre fronteiras (VICENTE, 2009).

\subsubsection{A moda brasileira no mercado internacional}

De acordo com apontamentos de Vicente (2009), Abest (2012), Apex (2012), Abit (2012) e Leitão (2009) a moda brasileira busca visibilidade no mercado internacional e os designers brasileiros têm se destacado em mídias internacionais, ganhando cada vez mais importância no contexto internacional (ABEST, 2012).

Viu-se também que a moda brasileira nos últimos anos ganhou destaque no mercado externo em função das cores, da diversidade e da ousadia dos produtos elaborados no Brasil (APEX, 2012; LEITÃO, 2009).

Por meio das entrevistas observou-se que os apontamentos da fundamentação teórica se confirmam e que a Brasilidade é um atributo importante para a internacionalização. No entanto, outros aspectos precisam ser tratados para consolidar o posicionamento da moda brasileira no mercado internacional. Com isso, entende-se que a inserção do produto de moda no mercado internacional ainda é baixa e os agentes de apoio à internacionalização, assim como os agentes ofertantes de moda brasileira, estão desenvolvendo projetos para estruturar o segmento para poderem atender às demandas internacionais. Tais achados são confirmados por meio da fala dos entrevistados, como ser verá adiante.

No entendimento do entrevistado Fernando Pimentel (A1), a moda brasileira ainda não se consolidou no mercado externo de maneira marcante, pois a internacionalização da moda nacional é recente, o projeto mais estruturado da internacionalização da moda brasileira foi iniciado em 2001. Assim, o entrevistado acredita que os designers brasileiros para se firmarem no mercado internacional devem utilizar a imagem do Brasil na moda mas devem respeitar o consumidor global. Ele acredita que os atributos da brasilidade: cores, estilo de vida, matérias-primas naturais e formas e volumes são os mais valorizados pelo mercado internacional, conforme pode ser observado no trecho a seguir:

Levar o que é novo, a personalidade brasileira, as características brasileiras, que são e contam com a boa vontade de que o Brasil hoje é uma referência positiva, antes era negativa, levar aquilo que ele é. Levando referências que o Brasil tem com uma 
linguagem universal, explorando materiais que o Brasil tem e que possam ser usados na linguagem universal porque é isto faz o produto diferente. Não pode fazer o mesmo que o europeu faz, se chega com um produto com uma matéria prima trabalhada, que tem essa pitada mais bacana de Brasil mas que o sujeito lá na Europa entenda que pode ser usado lá. Tem que levar o que é o Brasil, a qualidade de produção, os materiais que pouco se vê.

Ainda no entendimento de Fernando (A1), o Brasil está sendo mais valorizado no contexto internacional, mas ele se indaga até quando e acredita que isso dependerá da competência dos brasileiros.

Segundo o entrevistado André Hidalgo (A2) o mercado internacional valoriza o estilo de vida no brasileiro, assim como as cores, as aplicações e técnicas artesanais, as estampas e as formas e volumes. Para ele, há um movimento de internacionalização da moda brasileira, mas ainda é incipiente conforme observa-se no trecho seguinte:

As pessoas não estão falando moda brasileira lá fora, os brasileiros querem achar que estão falando, mas não é assim.... é obvio que as pessoas estão curiosas é obvio que as pessoas querem saber o que está sendo feito aqui, o Brasil é a bola da vez, mas não existe ainda um desejo de consumo pela moda brasileira, não a altura dos investimentos que a gente tem feito aqui que os próprios eventos como o SPFW e tudo mais,

No entendimento de A2 a moda brasileira ganhará mais destaque no mercado internacional à medida que reunir em sua oferta cor, sensualidade, conceito, qualidade e bom preço.

Para o entrevistado Antonio Haslauer da Costa, a mercado internacional valoriza na moda brasileira atributos como: o estilo de vida, cores, aplicações e técnicas artesanais, formas e volumes e estampas. Ele cita que o mercado internacional busca os mesmos atributos que busca de qualquer outro país, mas espera que o produto brasileiro tenha uma identidade que remeta a elementos básicos de referencial brasileiro e acredita que o mercado de moda brasileiro precisa compreender melhor os elementos que compõem a brasilidade na moda.

Além disso, o entrevistado menciona que o produto brasileiro deve ter atributos que justifiquem que o comprador internacional deixe de comprar de outra marca mundial para comprar de uma marca brasileira. Seu ponto de vista pode ser compreendido por meio da leitura de sua fala:

Se você é um comerciante que está operando no mercado há 10, 15 anos, provavelmente a proveniência do seu produto é da Europa, do Japão e do EUA, são marcas que com certeza você conhece com ressonância de mercado muito grande, se você vai apostar numa proveniência nova, numa marca nova, essa marca precisa 
justificar essa sua decisão, precisa trazer atributos que fortifiquem essa decisão de abandono de marcas tradicionais e de adquirir uma marca nova, que é um investimento importante, é uma investida. O produto brasileiro apresenta sem dúvida esses atributos, a partir do momento em que existe uma consciência do Brasil de missão da marca em termos de inovação, em termos de identidade, em termos de qualidade, em termos de missão de estilo que perdure, eu acredito que sim. Acho que existe uma grande necessidade de identificar componentes do made in brazil que são únicos ao Brasil e que muitas vezes são olhados com certo desdenho pelos fashionistas que tem um deslumbre mais expressivo com coisas de fora e pensar mais no algodão, da Paraíba, pensar na renda, em algumas dicas que são nossas, em alguns quesitos que são tipicamente brasileiros que poderiam ser laboratorizados para se tornar uma grande voz na moda internacional.

O entrevistado Evilásio Miranda (A4) segue o mesmo raciocínio de Antonio Haslauer da Costa e cita que o mercado internacional procura no produto de moda brasileira o mesmo que busca em qualquer fornecedor do mundo, ou seja, um produto com identidade, qualidade, com preço adequado oferecido por uma marca que tenha consistência no seu design e serviço. Evilásio, porém, não acredita que o comprador internacional esteja buscando um produto só por este ser brasileiro e diz:

Ele tá buscando do Brasil o mesmo que ele busca de todo fornecedor do mundo, um produto que tenha identidade, que tenha qualidade, e que tenha um preço adequado para o que ele oferece, vindo de uma marca que tenha profissionalismo, ou seja, que entregue o pedido tudo na data certinha e de uma marca que tenha consistência de produto e de estilo, que de uma coleção para a outra não pira e faz uma coisa totalmente diferente. Então eu acho que não é uma procura que diz respeito somente ao produto brasileiro, mas a qualquer produto.

No entanto, Evilásio Miranda (A4) menciona que o mercado internacional valoriza na moda brasileira o estilo de vida, a sensualidade, a forma descontraída e feliz das pessoas. Assim, os atributos de brasilidade na moda que esse entrevistado acredita que o mercado internacional valoriza são: o estilo de vida, as matérias primas naturais, as formas de volumes, as aplicações e técnicas artesanais e as estampas. Cabe destacar que Evilásio Miranda acredita que tais atributos podem ser apropriados por qualquer marca de qualquer país e cita o exemplo de uma marca francesa chamada Pain de Sucre (Pão de Açúcar) que utiliza, em suas publicidades, fotos do Rio de Janeiro.

Sob o ponto de vista da entrevistada Geni Rodio (A5) o mercado internacional valoriza os seguintes atributos na moda brasileira: o estilo de vida, as cores, as matérias primas naturais, a estampa e as formas. No entanto, a entrevistada pondera que o resultado da inserção da moda brasileira no mercado internacional ainda é muito pequeno. Mas ela cita que algumas marcas estão conseguindo conquistar mercado entre fronteiras e diz que o sucesso dessa inserção está 
sendo construído com base na identidade da marca, na sua autenticidade, persistência e consistência em design e cita dois exemplos como pode ser observado no trecho seguinte:

Tem algumas marcas que conseguiram buscar e encontrar um jeito de comunicar, por exemplo, você tem a Cecília Prado, que faz um trabalho exclusivamente de tricô, ela vem de uma família que vende tricô lá de Jacutinga, que é um polo produtor, e ela se apropriou disso, ela fez um trabalho com uma identidade muito própria muito forte, e ela acreditou e foi para fora, e também não se constrói uma imagem da noite para o dia. Não adianta você ter um produto, ir fazer uma tentativa, e voltar [...], se você não persistir você não desenvolve isso. A Alessa, é outra pessoa que fez um caminho interessante, ela trabalha quase, basicamente em cima de cor e estampa, e ela tem uma forma muito própria de fazer as estampas dela. Ela não tá preocupada com a moda com a tendência com nada, ela faz a estampa de acordo com o interesse dela e aquilo que é inspiração dela e ela encontrou um caminho, encontrou alguns clientes é pequeno, é um trabalho ainda, mas é uma empresa que está conseguindo manter seus clientes fora do Brasil.

De acordo com o entrevistado Nic Cox (A6), que compra coleções de moda do Brasil há quatro anos, a moda Brasileira ainda representa uma pequena parte das transações da sua empresa, ele quer aumentar o mix de produtos brasileiros, pois, segundo ele este "é o momento de comprar do Brasil, as pessoas estão procurando o Brasil, estão interessadas no Brasil. Agora é o momento de considerar as coisas e mudar”. Para o entrevistado A6 a moda brasileira que se destaca no mercado internacional é a das estações de verão e primavera. Ele diz que a moda brasileira não é adaptada para inverno da Rússia, assim, ele compra produtos de moda praia e piscina.

Na opinião de Cox (A6), o consumidor final ainda não valoriza a moda brasileira, ele acredita que a imprensa e mídia valorizam, e depois o público final começará a conhecer o produto de moda brasileiro e demanda-lo, ou seja, primeiro os compradores e os jornalistas valorizam depois as pessoas seguem. Ele menciona, porém que as pessoas valorizam a moda casual que o Brasil faz e o estilo de vida do brasileiro que se reflete nesta moda casual, por isto, o entrevistado acredita que a moda brasileira não deve se apoiar somente no que é feito a mão, mas sim em boa moda, com design globalizado.

Para entrevistadas Matute (A7) e Lopez (A8) a moda praia brasileira é referencia para elas. Seus consumidores não compreendem a imagem do Brasil na moda, mas valorizam as estampas e cores dos atributos da brasilidade na moda.

Por fim, o entrevistado Renoux Hughes (A9), menciona que seus consumidores não têm uma 
imagem de moda do Brasil, ou seja, não compreendem o conceito da moda brasileira, mas gostam do Brasil, valorizam a sustentabilidade e a ecologia que o produto de moda brasileiro carrega e principalmente gostam do Brasil por ser um país sem inimigos. Por isso, o entrevistado entende que seu público valoriza os seguintes atributos de brasilidade na moda: estilo de vida, formas e volumes, cores, estampas representações do Brasil e símbolos nacionais e matérias primas naturais.

A partir da análise das respostas dos entrevistados, percebe-se que a inserção da moda brasileira no mercado internacional ainda está em estágio inicial, assim, há necessidade de se comunicar a imagem do Brasil no contexto da moda no mercado internacional e com esae objetivo viu-se que trabalhos de associações estão sendo desenvolvidos.

Observou-se também que o mercado ofertante de moda brasileira precisa compreender e utilizar, de forma adequada, os atributos que compõem a imagem do Brasil na moda. No âmbito desta pesquisa, identificou-se que os atributos da brasilidade que são mais valorizados pelo mercado internacional são: estilo de vida, formas e volumes, cores e estampas. Na moda praia os tecidos também são valorizados. As matérias primas naturais e as aplicações e técnicas artesanais também são atributos valorizados, mas não tanto quanto o estilo de vida, formas e volumes, cores e estampas.

Assim, é importante verificar se os designers brasileiros já estão se apropriando de tais atributos para distinguir sua oferta. Ao longo das entrevistas, alguns agentes de mercado mencionaram marcas que estão desenvolvendo um bom trabalho de identidade de marca aliado aos atributos da brasilidade. Por isso, criou-se uma subdimensão, neste capítulo, para relacionar os profissionais que foram mencionados pelos entrevistados.

\subsubsection{A apropriação dos atributos da imagem do país de origem na moda}

De acordo com Fernando Pimentel (A1) a apropriação da brasilidade na moda é crescente, já é entendida e qualificada. Ele percebe que os designers brasileiros estão utilizando os atributos da brasilidade, pois "são bonitos, são originais, estão sendo descobertos e o Brasil está gostando mais de si, acho que é um conjunto de fatores, são bonitos, já existiam, mas eles não eram valorizados". 
Fernando Pimentel (A1) cita que os designers Ronaldo Fraga e Walter Rodrigues têm explorado de forma interessante a brasilidade. Outros designers e marcas mencionados pelo entrevistado A1, que utilizam a brasilidade na moda, mas cada um com sua particularidade são: Isabela Capeto, Glória Coelho, Farm, Osklen, Blue Man, Hui Clo, Maria Bonita, Ellus, Iódice, Fórum.

Na opinião de Antonio Haslauer da Costa (A3) a marca Osklen tem capacidade de representar o estilo de vida do brasileiro. Ele também menciona Lenny e Água de Coco no segmento de moda praia. Tanto Evilásio Miranda (A4), quanto Geni Rodio (A5) e Antonio Haslauer da Costa (A3) mencionam o trabalho de Cecília Prado com o tricô.

A Neon é outra marca que foi citada por André Hidalgo (A2), Antonio Haslauer da Costa (A3) e Renoux Hughes (A9) pela brasilidade em suas estampas.

Diferente de Fernando Pimentel (A1) que acredita que a Brasilidade na moda é qualificada, Geni Rodio (A5) entende que ainda há muito trabalho a ser feito no sentido de entendimento da brasilidade e da forma como as marcas devem se apropriar desses atributos sem produzir caricaturas. Ela menciona que a Alessa, a Farm e o designer Ronaldo Fraga fazem um bom trabalho de comunicação da identidade e dos atributos que utilizam da brasilidade.

A entrevistada Andrea Lopez (A8), citou Rosa Chá, Água de Coco, Salinas e Cia. Marítima como marcas que se apropriam dos atributos da brasilidade. Nic Cox (A6) citou Adriana Degreas e Renoux Hughes (A9) mencionou André Lourenço, Clube Bossa, Ronaldo Fraga e Reinaldo Lourenço.

\subsubsection{Formas de diferenciação do produto de moda no mercado internacional}

Conforme apresentado no item 2.1.1 (Fontes de Vantagem Competitiva) da fundamentação teórica, existem algumas formas que as empresas podem utilizar para distinguir suas ofertas, as quais podem ser observadas no quadro 15 e que foram discutidas anteriormente nesta dissertação. 
Quadro 15 - Formas de distinção de oferta

\begin{tabular}{|c|c|}
\hline Forma de diferenciação & Aporte teórico \\
\hline Por Produto & Kotler e Keller (2006) \\
\hline Por imagem & Mintzberg (2006); Kotler e Keller (2006); \\
& Zatta et al. $(2011) ;$ \\
Brïdson e Evans (2004).
\end{tabular}

Neste estudo buscou-se compreender quais atributos da imagem do país de origem representam uma fonte de vantagem competitiva. No entanto, ao longo da pesquisa de campo, observou-se que os agentes de mercado mencionaram outras formas importantes de diferenciação no segmento da moda para competição no mercado internacional. Assim, observa-se que a diferenciação no segmento da moda deve abranger diversos aspectos da oferta, ou seja, a distinção da oferta deve abarcar diversos elementos, como poderá ser compreendido por meio da fala dos entrevistados.

De acordo com o entrevistado Fernando Pimentel (A1) as marcas de moda devem distinguir sua oferta fundamentalmente com base na diferenciação por design e por qualidade, com um preço adequado. Ele menciona que a diferenciação por imagem, por suporte e serviço, por sustentabilidade, por inovação e pela imagem do país de origem também são importantes, no entanto, o design e a qualidade são os principais elementos distintivos da oferta de moda em sua opinião.

No entendimento de André Hidalgo (A2), o mercado internacional busca em produtos de moda o design com bom preço. Ele acredita que para ter um bom design, a marca deve ousar e estar sempre inovando seus produtos, por isso, também destaca a diferenciação por inovação. 
Segundo opinião de Antonio Haslauer da Costa (A3), o mercado internacional busca em produtos de moda "tendências atemporais", que, segundo ele são: "qualidade, pertinência, autoridade, constância em termos de visão de produto e qualidade de produto [...] que o produto tenha uma voz, e que essa voz se traduza em uma inspiração, que seja um estilo na verdade". Logo, percebe-se que a qualidade do produto e o seu design, são as principais formas de diferenciação apontadas pelo entrevistado.

Antonio Haslauer da Costa (A3) destaca também outras duas formas de diferenciação. A distinção por suporte e serviços, que para ele são pontos que devem ser desenvolvidos pelas marcas brasileiras, pois representa uma fragilidade da moda brasileira. Destaca também a diferenciação pela imagem do país de origem, pois ele acredita que existe muito interesse pelo Brasil, mas que ainda deve-se construir uma imagem da moda brasileira e uma apropriação adequada dos atributos que são expressivos do Brasil tornar esta forma de distinção mais efetiva para as empresas que a utilizarem.

Para Evilásio Miranda da Costa (A4), o mercado internacional busca em produtos de moda: identidade, qualidade ofertados a preços justos, com serviços e suporte adequados, vindo de uma marca com consistência entre as coleções. Assim, ele entende que a imagem da marca, que é reproduzida por meio da identidade da marca é a principal forma de distinção na moda no contexto internacional.

No entendimento de Geni Rodio (A5), no mercado de moda a oferta deve se distinguir por meio de um conjunto de formas de diferenciação. Ela menciona que a oferta deve ser uma combinação entre design, atendimento (suporte e serviço), obrigatoriamente com qualidade que abrange conforto e modelagem a um preço adequado. Para ela sustentabilidade e inovação também são formas distintivas importantes que devem fazer parte do processo de desenvolvimento do produto. Rodio (A5) acredita que a imagem do país de origem também é uma forma de distinção importante, porém deve fazer parte da proposta de distinção da oferta, pois de forma isolada não suprirá a necessidade de atributos que o mercado demanda.

A fala de Geni Rodio (A5) vai ao encontro dos apontamentos de Zatta et al. (2011). Tais autores citam que o agente ofertante deve ter consciência de que oferecer um produto com qualidade e preço adequado ao seu público alvo, não são os únicos atributos para conquistar e manter seus clientes. Assim, acreditam que os fatores que diferenciam produtos de moda são: 
(1) inovação, no sentido de permitir a melhoria dos processos ao aumentar a produtividade e agregar valor aos produtos; (2) o design, não só do produto, mas a forma como esse é apresentado ao público, abarcando desde a logomarca, a embalagem, o material de comunicação e a sinalização no ponto de vendas, podendo ser incorporado na cadeia produtiva, e (3) identidade por meio do design único.

Para o entrevistado Nic Cox (A6) a oferta diferenciada de moda deve balancear o design e a qualidade, com um bom preço. Além disso, o comprador deve sentir-se seguro de que receberá o pedido comprado, por isso, suporte e serviço mostram-se importantes na proposta de oferta. Ele cita que a imagem do país também é importante e que, no caso do Brasil, deve ser explorada em função do posicionamento econômico que o Brasil vive nesse momento.

A entrevistada Nancy Matute (A7) acredita que um produto diferenciado no segmento da moda deve se distinguir por design e pela qualidade. A entrevistada Andrea Lopez (A8), concorda com a opinião de Matute, mas acrescenta que a imagem do país de origem também tem importância no conjunto da oferta.

No entendimento do entrevistado Renoux Hughes (A9), suporte e serviços, design, qualidade, sustentabilidade e a imagem do país de origem, são as formas de distinção que devem ser combinadas para se ofertar uma boa proposta de moda. Hughes evidencia a importância do apelo da sustentabilidade na oferta confirmando os apontamentos de autores como Rocha et al. (2005) e Emerenciano e Pires (2006) de que o segmento deve considerar no processo de desenvolvimento de produto de moda e do seu design, uma série de elementos, como a busca pela sustentabilidade; o impacto ambiental e suas consequências, a inter-relação entre a economia e a globalização.

Renoux Hughes (A9) menciona também que as marcas de moda brasileira ainda precisam se desenvolver muito na parte de suporte e prestação de serviços. Por fim, destaca fortemente a importância de transmitir a mensagem da brasilidade por meio do produto e da marca.

Interessante notar que os entrevistados Fernando Pimentel (A1), Geni Rodio (A5) e Renoux Hughes (A9) citam que a diferenciação por imagem da marca no mercado internacional é importante, porém muito custosa, pois demanda a abertura de pontos de vendas e investimento em mídias, representando uma forma de distinção difícil de ser utilizada pelas 
marcas. $\mathrm{O}$ quadro 16 resume as formas de diferenciação destacadas pelos entrevistados para oferta no segmento da moda no mercado internacional.

Quadro 16 - Formas de diferenciação da oferta de moda no entendimento dos entrevistados

\begin{tabular}{|c|c|c|c|}
\hline Entrevistados & $\begin{array}{l}\text { Principais formas de } \\
\text { diferenciação no } \\
\text { entendimento do } \\
\text { entrevistado }\end{array}$ & $\begin{array}{c}\text { Outras formas de } \\
\text { diferenciação importantes, } \\
\text { porém menos relevantes }\end{array}$ & $\begin{array}{c}\text { Formas de } \\
\text { diferenciação } \\
\text { pouco destacadas }\end{array}$ \\
\hline Fernando Pimentel (A1) & $\begin{array}{l}\text { Design, qualidade com preço } \\
\text { adequado. }\end{array}$ & $\begin{array}{l}\text { Imagem da marca, suporte e } \\
\text { serviços, sustentabilidade, } \\
\text { inovação e pela imagem do } \\
\text { país de origem }\end{array}$ & \\
\hline André Hidalgo (A2) & $\begin{array}{l}\text { Design, imagem da marca e } \\
\text { inovação. }\end{array}$ & $\begin{array}{l}\text { Qualidade, sustentabilidade } \\
\text { e pela imagem do país de } \\
\text { origem }\end{array}$ & Suporte e serviços \\
\hline $\begin{array}{ll}\text { Antonio } & \text { Haslauer } \\
\text { Costa (A3) } & \end{array}$ & $\begin{array}{l}\text { Suporte e serviços, design, } \\
\text { qualidade, inovação e pela } \\
\text { imagem do país de origem }\end{array}$ & $\begin{array}{lll}\text { Imagem da marca } & \text { e } \\
\text { sustentabilidade } & & \end{array}$ & \\
\hline Evilásio Miranda (A4) & $\begin{array}{l}\text { Imagem da marca e } \\
\text { qualidade }\end{array}$ & $\begin{array}{l}\text { Suporte e serviços, design, } \\
\text { inovação e pela imagem do } \\
\text { país de origem }\end{array}$ & Sustentabilidade \\
\hline Geni Rodio (A5) & $\begin{array}{l}\text { Suporte e serviço, design, } \\
\text { qualidade e pela imagem do } \\
\text { país de origem }\end{array}$ & Sustentabilidade e Inovação & Imagem da marca \\
\hline Nic Cox (A6) & $\begin{array}{l}\text { Design, qualidade e serviços } \\
\text { e suporte }\end{array}$ & $\begin{array}{l}\text { Imagem do país de origem, } \\
\text { sustentabilidade e inovação }\end{array}$ & Imagem da marca \\
\hline Nancy Huam Matute (A7) & Qualidade e design & $\begin{array}{l}\text { Imagem do país de origem, } \\
\text { sustentabilidade, serviços e } \\
\text { suporte e inovação }\end{array}$ & Imagem da marca \\
\hline Andrea Lopez (A8) & $\begin{array}{l}\text { Qualidade, design e pela } \\
\text { imagem do país de origem }\end{array}$ & $\begin{array}{l}\text { Imagem da marca, } \\
\text { sustentabilidade, serviços e } \\
\text { suporte e inovação }\end{array}$ & \\
\hline Renoux Hugues (A9) & $\begin{array}{l}\text { Suporte e serviços, design, } \\
\text { qualidade, sustentabilidade e } \\
\text { pela imagem do país de } \\
\text { origem }\end{array}$ & Inovação & Imagem da marca \\
\hline
\end{tabular}

Observa-se, assim, dentro do contexto desta pesquisa, que a oferta de moda no mercado internacional deve envolver os seguintes elementos distintivos: design, qualidade, que a empresa ofereça suporte e serviços e que a marca desenvolva os atributos relacionados ao país de origem em sua oferta e que a identidade da marca esteja presente em todos estes elementos.

Tal resultado reforça os apontamentos de Rybalowski (2008) de que o produto de moda diferenciado agrega diversos atributos e qualidades intrínsecos, que são relacionados ao custo da matéria-prima e de fabricação (qualidade do produto), e extrínsecos, no que tange ao apelo e ao design, que são percebidos pelo consumidor e que estão em sintonia direta com seus desejos e expectativa. 
Os entrevistados enfatizaram a diferenciação por design como forma fundamental de distinção. Tal achado confirma os apontamentos de Kotler e Keller (2006) quando destacam a importância do design de produto para a diferenciação da oferta em mercados em que a concorrência é intensa a tecnologia e o preço não se mostram atributos suficientes para diferenciar a oferta. Por isso, os autores apontam que o design é um fator que proporciona constantemente a vantagem competitiva, consistindo no conjunto de características que influenciam na aparência e no funcionamento do produto sob o entendimento das exigências do cliente. Kotler e Keller (2006) mencionam que esse atributo se faz de particular importância na elaboração e comercialização de roupas, conforme ratificado por este estudo.

Após a compreensão sobre entendimento dos entrevistados a cerca das formas de distinção da oferta de moda no mercado internacional, eles foram indagados sobre a imagem do Brasil como fonte de vantagem competitiva na moda no mercado internacional.

No entendimento de Fernando Pimentel (A1) a brasilidade na moda é crescente e é entendida. Ele acredita que a imagem do Brasil poderá ser uma fonte de vantagem competitiva se o segmento da moda brasileira realizar um trabalho como os Japoneses fizeram, de levar a cultura com uma linguagem acessível ao mundo. Ele entende que o Brasil tem condição de fazer isso, pois é um país rico, diversificado e não é hostilizado. No entanto, ele menciona que isso acontecerá se os agentes de moda brasileira trabalharem sua oferta com atributos de brasilidade aliados ao design e a qualidade, conforme pode ser compreendido por meio do trecho a seguir:

Então eu acho que a moda brasileira, na medida em que o país continue a crescer vai encontrar um espaço próprio, não porque é Brasil, mas em função de competência e qualidade em design, de construção de melhoria deste processo para chegar com o nosso life style no mundo e com isso entender a lógica (exemplo da moda Japonesa, na década de 70 que firmou uma posição que antigamente não existia - criar uma posição consolidada). O Brasil tem muito espaço para caminhar nesta linha.

André Hidalgo (A2) tem o mesmo entendimento que Fernando Pimentel (A1), que pode ser compreendido por meio do seguinte trecho:

Acho que os atributos da brasilidade serão valorizados, isso que vai determinar uma cara para a moda brasileira, usar esses elementos para um conceito globalizado, mas que tenha esse diferencial, que tenha essa assinatura, que as pessoas olhem e digam "ah isso é brasileiro".

Para Antônio Haslauer da Costa (A3) os atributos da brasilidade também representam fonte de vantagem competitiva no mercado internacional, mas diz que é importante tomar cuidado 
com a forma como esses elementos são trabalhados, conforme trecho a seguir:

\begin{abstract}
Sem dúvida, eu acho que a brasilidade é fonte de vantagem competitiva. Sem o apelo da caricatura eu acho que se nós trouxermos os atributos que são expressivos no Brasil, que trouxer o design, a sensualidade, uma roupa esportiva que o estilo do brasileiro por si só é esportivo, ele usa isso de uma maneira diferente, eu acho que se as marcas traduzirem o estilo do Brasil isso de dentro do Brasil para fora, eu acho que vai existir um interesse muito grande do mercado. Existe muito interesse pelo Brasil, só que existe muito pouca oferta, é muito fragmentado a nossa oferta.
\end{abstract}

Antonio (A3) acredita que a criatividade da moda brasileira é um elemento valorizado pelo mercado internacional. Por isso, sugere que os produtos que saem do Brasil devem ter componente criativo e inovador bastante expressivo.

No entendimento de Evilásio Miranda (A4), os atributos da brasilidade na moda representam fonte de vantagem competitiva no mercado internacional, no entanto, o entrevistado menciona que se o Brasil não desenvolver um bom trabalho de imagem, outras marcas, de outras nacionalidades poderão se apropriar de tais atributos e utilizá-los em suas ofertas.

Para a entrevistada Geni Rodio (A5) a imagem do país de origem no contexto da moda é uma forma distintiva importante, porém ela acredita que a oferta de moda não pode ser composta somente por esse elemento distintivo, conforme pode ser observado no trecho seguinte:

\begin{abstract}
Eu acho que a imagem do país de origem tem um peso importante [...] Existe uma simpatia muito grande pelo Brasil, então se a gente puder atrelar tudo isso, e usar tudo isso, eu acho que o país de origem, o made in Brazil, ele começa a ter um certo peso e começa a exercer um encantamento [...] eu não posso te garantir que isso seja a única fonte, mas eu acho que é um caminho que vai minimamente nos diferenciar, agora, desde que ele seja dessa forma, e não seja explícito nem, e você tem que ser contemporâneo, não tem jeito de não ser contemporâneo, para não ficar uma coisa caricata, por isso que precisa do design, o design existe exatamente para isso, é para transformar as ideias em produtos usáveis, produtos confortáveis, produtos de função. Essa é a função do design no processo criativo.
\end{abstract}

No entendimento dos compradores internacionais Nic Cox (A6), Nancy Huam Matute (A7), de Andrea Lopez (A8) e de Renoux Hughes (A9) a imagem do Brasil é importante para diferenciar a oferta de moda, pois eles acreditam que seus clientes têm expectativas com relação ao Brasil em função da presença do país no contexto global atual. Porém, esses entrevistados citam que a imagem do Brasil na moda ainda não é totalmente compreendida, então, para eles, o produto de moda deve se alicerçar em outros elementos diferenciadores e, junto a isso, deve-se desenvolver a imagem do Brasil na moda. 
A partir da fala dos entrevistados entende-se que a imagem do país de origem pode ser uma fonte de vantagem competitiva, mas não deve ser utilizada de forma isolada e esta imagem ainda precisa ser compreendida pelo mercado internacional para fortalecer a oferta de moda brasileira entre fronteiras.

Assim, o entendimento sobre o conjunto de elementos distintivos que a oferta de moda deve integrar e a importância da imagem do país de origem na competição internacional, fortalecem os apontamentos de Bruno et al. (2009) de que o Brasil tem ativos escassos que a indústria têxtil precisa aprender a utilizar, como: a diversidade cultural e técnica de processos artesanais; a estrutura fabril e a experiência técnica e comercial dessa indústria; os novos talentos que estão sendo reconhecidos no mundo da moda pelo design inovador; assim como a imagem positiva de símbolos nacionais.

Os achados também reforçam a visão de Giraldi e Tornavoi (2005) de que a imagem do Brasil pode ser considerada um atributo para empresas que buscam comercializar entre fronteiras, tornando-se assim, a base para a estruturação de uma estratégia de diferenciação de produtos brasileiros.

\subsubsection{Entraves à inserção da moda brasileira no mercado internacional}

Ao longo da fundamentação teórica verificou-se que a moda brasileira enfrenta algumas dificuldades no seu processo de internacionalização, conforme apontado por autores como Filho (2011 in IEMI, 2011), Zatta (et al., 2011), Bruno et al. (2009), Costa e Rocha (2009) e Manetti (2006). Os principais entraves apontados por estes autores estão relacionados no quadro 17.

A fase empírica desta pesquisa não buscou verificar quais os entraves fazem parte do processo de inserção da moda brasileira no mercado externo, no entanto, diversos entrevistados apontaram tais aspectos e mencionaram outros dez que não foram identificados na fundamentação teórica. Como esses entraves interferem diretamente na competitividade da oferta brasileira entre fronteiras, decidiu-se criar uma parte da análise destinada a apresentar tais relatos. 
Quadro 17 - Entraves à internacionalização da moda brasileira

\begin{tabular}{|l|l|}
\hline Entrave & Autor \\
\hline Elevada carga tributária & Filho (2011 in IEMI, 2011), Zatta (et al., 2011) \\
\hline Juros altos & Filho (2011 in IEMI, 2011), Zatta (et al., 2011) \\
\hline Custo dos encargos sociais & Filho (2011 in IEMI, 2011), Zatta (et al., 2011) \\
\hline Câmbio & Filho (2011 in IEMI, 2011), Zatta (et al., 2011) \\
\hline $\begin{array}{l}\text { Crescimento da entrada de produtos } \\
\text { importados }\end{array}$ & Filho (2011 in IEMI, 2011), Zatta (et al., 2011) \\
\hline $\begin{array}{l}\text { Infraestrutura precária (logística, portos, } \\
\text { aeroportos, matriz energética e educação). }\end{array}$ & Bruno et al. (2009), Costa e Rocha (2009) \\
\hline Dificuldade de acesso a financiamentos & Costa e Rocha (2009) \\
\hline $\begin{array}{l}\text { Domínio do mercado por grupos Italianos, } \\
\text { Franceses, Ingleses e recentemente } \\
\text { Americanos. }\end{array}$ & Manetti (2006) \\
\hline Concorrência asiática & Costa e Rocha (2009) \\
\hline
\end{tabular}

Fernando Pimentel (A1) cita que a moda brasileira teve uma fase que estava mais presente no mercado internacional por meio de desfiles, no entanto, depois que o câmbio aumentou a competitividade das marcas foi prejudicada e algumas deixaram de se apresentar em semanas de moda internacional.

Um aspecto que foi mencionado por grande parte dos entrevistados como um entrave à internacionalização da moda brasileira e que não foi identificado na literatura, refere-se ao fato de algumas marcas ainda persistirem em produzir suas coleções com base nas peças que foram lançadas na Europa, ou seja, o resquício de cópia.

André Hidalgo (A2) entende que ainda existem marcas brasileiras que copiam a moda internacional. O posicionamento do entrevistado Antônio Haslauer da Costa (A3) segue o de André Hidalgo (A2). Para Haslauer (A3), algumas marcas deixam de imprimir a identidade brasileira na moda para ter aceitação mais rápida no mercado externo e, para isso, copiam peças lançadas na Europa. Observa-se seu ponto de vista por meio do seguinte trecho: "existe muito essa tendência desavisada de marcas que querem penetrar no mercado internacional em chegar com uma linguagem muito similar àquela imagem reinante no momento, abandonando muitas vezes a identidade da própria marca".

Haslauer (A3) acredita que as marcas que reproduzem prejudicam o processo de criação da imagem de moda brasileira, pois entende que o produto brasileiro, para ter espaço no mercado internacional, precisa se diferenciar e não reproduzir os modelos europeus. Sua opinião pode ser compreendida a partir do seguinte trecho: 
Eu acho que o Brasil, antes de mais nada, precisa olhar muito criticamente para as marcas que tem no mercado e apontar alguns quesitos que tem sido contra produtivos no decorrer da história da moda brasileira. Eu acho que é derivativo e sem dúvida precisa ser contado como um grande um mico desse processo, o produto do Brasil não é barato, então se esse produto é derivado de um outro produto internacional, ou seja, cópias de inspiração, eu acho que a moda brasileira perde muito nisso. Por que você compraria cópia cara quando você tem sub-marcas made in china com esse papel, por que comprar produto derivativo? Então, isso precisa ser uma missão muito bem trabalhada.

Antônio Haslauer da Costa (A3) menciona também, o preço do produto brasileiro que é alto em decorrência do custo Brasil (elevada carga tributária, encargos sociais, câmbio) e pela precificação incorreta que é realizada pelas marcas. Assim, sugere que um trabalho de precificação correto deve ser realizado pelas marcas junto a seus fornecedores, conforme pode ser observado no trecho:

Existem vários elementos, existe o custo Brasil, que é exagerado, existe uma penalização da moda, uma penalização fiscal da moda no Brasil, existe também um laisser faire no que se refere à pesquisa e precificação de produtos, existem peças que são glamorizadas, mas tem um preço mais acessível. Precisa de um trabalho de precificação de produtos e um trabalho mais alinhado com os fornecedores vai ajudar a diminuir os custos.

Para Evilásio Miranda da Costa (A4) outra dificuldade é o fato de o mercado nacional não ter acesso a boas matérias primas. No entanto, no seu entendimento o principal entrave à internacionalização da moda brasileira é o fato de os empresários brasileiros não terem a mente preparada para a penetração no mercado externo, ou seja, a falta de profissionalismo. Ele cita que algumas marcas dão prioridade para atender o mercado nacional, assim, às vezes deixam de entregar pedidos para clientes internacionais para atender a demanda local.

Geni Rodio (A5), assim como Evilásio, cita a falta de envolvimento dos profissionais com a moda como outro elemento negativo da moda brasileira. Para ela muitas marcas somente produzem moda, são indústrias de vestuário, pois não há um comprometimento da empresa com o desenvolvimento de produtos diferenciados. Para a entrevistada (A5), essas empresas que só seguem tendências e reproduzem vestuários, sem apelo da diferenciação, enfrentarão problemas no âmbito estratégico no futuro.

Miranda (A4) e Rodio (A5) destacam outro aspecto que dificulta a penetração da moda brasileira no mercado internacional, que é a falta de consistência do estilo da marca, da sua identidade no design entre coleções. Assim, no entendimento deles, muitas marcas buscam desenvolver uma identidade única e criam suas coleções com base nessa identidade, no 
entanto, muitas deixam de lado os elementos que compõem a sua identidade para produzir peças que tenham apelo de tendência, que são mais comerciais, ofertando produtos completamente diferentes do que na coleção anterior.

O abandono da identidade, mencionado também por Antônio Haslauer da Costa (A3), faz com que o comprador internacional desista de comprar dessa marca, pois não consegue compreender qual é a proposta de produto que a empresa está buscando ofertar. O entendimento dos entrevistados A3, A4 e A5, podem ser compreendidos por meio da fala de Rodio (A6), conforme trecho a seguir:

\begin{abstract}
A marca precisa ter a sua história, e precisa acreditar e seguir o seu estilo, porque se você não segue o seu estilo você não fideliza [...], mas se você desenvolve um estilo, desenvolve uma modelagem interessante, uma coisa boa, e você vai e faz uma coleção, as pessoas compram um pouquinho e começam a sentir que você tem uma modelagem interessante que veste bem ao público a que se destina e tudo bem. Na próxima coleção em função da tendência, que o todo mundo chama de tendência [...] você esquece tudo aquilo que você fez, o jeito que você fez, porque você precisa ser moderno, porque você precisa tá antenada, ai você vai e esquece um pouco daquilo em função de privilegiar aquilo que você acha que é o substrato que vai ficar importante. Aquele cliente que comprou que gostou que achou legal que vestiu e pensou 'puxa que coisa legal', quando ele volta a procurar a nova coleção ele não encontra mais nada daquilo. Isso acontece muito com as marcas brasileiras fora do Brasil, entendeu? Elas estão em fase de construção, e a construção passa inclusive por isso.
\end{abstract}

Essa entrevistada (A5) menciona também como entraves: o custo Brasil, o câmbio, a logística, as plataformas de produção, a burocracia nos processos de exportação, a mão de obra que deixou de receber treinamento e motivação adequados e a imagem de falta de comprometimento que o brasileiro tem no mercado internacional com relação à entrega de produtos.

O entrevistado Nic Cox (A6), assim como o entrevistado Renoux Hughes (A9), comentam que as marcas de moda brasileiras não desenvolvem produtos para o inverno adaptado à temperatura que se faz na Europa e na Rússia. Assim, o mercado internacional só compra moda brasileira para as estações de verão e de inverno, o que torna o ciclo de compras muito longo e dificulta a inserção das marcas brasileiras em outros mercados.

O entrevistado Renoux Hughes mencionou outros aspectos que dificultam a penetração da moda brasileira em outros mercados como: 1) a rotatividade de pessoas dentro das empresas que prejudica o desenvolvimento do relacionamento empresa - comprador; 2) a qualidade da 
costura que, segundo ele, é inferior à costura chinesa; 3) o controle de qualidade dos processos e, 4) os preços que são os mesmos de produtos Italianos e Espanhóis.

\section{Quadro 18 - Entraves à internacionalização da moda brasileira segundo os entrevistados}

\begin{tabular}{|c|c|c|}
\hline Entrave & Autor & Entrevistado \\
\hline Elevada carga tributária & $\begin{array}{l}\text { Filho (2011 in IEMI, } \\
\text { 2011), Zatta (et al., 2011) }\end{array}$ & Antônio Haslauer da Costa (A3) \\
\hline Juros altos & $\begin{array}{l}\text { Filho (2011 in IEMI, } \\
\text { 2011), Zatta (et al., 2011) }\end{array}$ & $\begin{array}{l}\text { Não foi mencionado pelos entrevistados, } \\
\text { mas entende-se que este influencia no } \\
\text { preço do produto final. }\end{array}$ \\
\hline Custo dos encargos sociais & $\begin{array}{l}\text { Filho (2011 in IEMI, } \\
\text { 2011), Zatta (et al., 2011) }\end{array}$ & Antônio Haslauer da Costa (A3) \\
\hline Câmbio & $\begin{array}{l}\text { Filho (2011 in IEMI, } \\
\text { 2011), Zatta (et al., 2011) }\end{array}$ & $\begin{array}{l}\text { Fernando Pimentel (A1), } \\
\text { Antônio Haslauer da Costa (A3), } \\
\text { Geni Rodio Ribeiro (A5), }\end{array}$ \\
\hline $\begin{array}{l}\text { Crescimento da entrada de } \\
\text { produtos importados }\end{array}$ & $\begin{array}{l}\text { Filho (2011 in IEMI, } \\
\text { 2011), Zatta (et al., 2011) }\end{array}$ & $\begin{array}{l}\text { André Hidalgo (A2), } \\
\text { Renoux Hughes (A9) }\end{array}$ \\
\hline 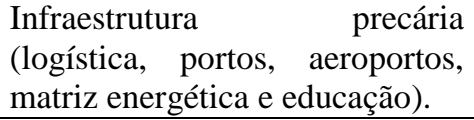 & $\begin{array}{l}\text { Bruno et al. (2009), Costa } \\
\text { e Rocha (2009) }\end{array}$ & $\begin{array}{l}\text { Geni Rodio Ribeiro (A5), } \\
\text { Renoux Hughes (A9) }\end{array}$ \\
\hline $\begin{array}{l}\text { Dificuldade de acesso a } \\
\text { financiamentos }\end{array}$ & Costa e Rocha (2009) & Não foi mencionado pelos entrevistados. \\
\hline $\begin{array}{l}\text { Domínio do mercado por grupos } \\
\text { Italianos, Franceses, Ingleses e } \\
\text { recentemente Americanos. }\end{array}$ & Manetti (2006) & Geni Rodio Ribeiro (A5) \\
\hline Concorrência asiática & Costa e Rocha (2009) & $\begin{array}{l}\text { André Hidalgo (A2), } \\
\text { Antônio Haslauer da Costa (A3), } \\
\text { Renoux Hughes (A9) }\end{array}$ \\
\hline $\begin{array}{l}\text { Resquício de reprodução de } \\
\text { coleções lançadas na Europa }\end{array}$ & & $\begin{array}{l}\text { Fernando Pimentel (A1), } \\
\text { André Hidalgo (A2), } \\
\text { Antônio Haslauer da Costa (A3) }\end{array}$ \\
\hline $\begin{array}{l}\text { Falta de profissionalismo na } \\
\text { formação de preço por parte do } \\
\text { ofertante - produtos com preços } \\
\text { elevados }\end{array}$ & & $\begin{array}{l}\text { Antônio Haslauer da Costa (A3), } \\
\text { Geni Rodio Ribeiro (A5), } \\
\text { Renoux Hughes (A9) }\end{array}$ \\
\hline $\begin{array}{l}\text { Mentalidade do empresário } \\
\text { brasileiro }\end{array}$ & & Evilásio Miranda da Costa (A4) \\
\hline $\begin{array}{l}\text { Dificuldade de acessar matéria } \\
\text { prima de qualidade }\end{array}$ & & Evilásio Miranda da Costa (A4) \\
\hline $\begin{array}{l}\text { Escassez de mão de obra } \\
\text { qualificada }\end{array}$ & & Geni Rodio Ribeiro (A5) \\
\hline $\begin{array}{l}\text { Rotatividade dos funcionários } \\
\text { nas empresas }\end{array}$ & & Renoux Hughes (A9) \\
\hline Deficiência na costura & & Renoux Hughes (A9) \\
\hline $\begin{array}{l}\text { Falta de consistência do estilo } \\
\text { entre coleções }\end{array}$ & & $\begin{array}{l}\text { Antônio Haslauer da Costa (A3) } \\
\text { Evilásio Miranda da Costa (A4) } \\
\text { Geni Rodio Ribeiro (A5) }\end{array}$ \\
\hline $\begin{array}{l}\text { Moda brasileira não desenvolve } \\
\text { produtos de inverno adaptados } \\
\text { para o mercado internacional. }\end{array}$ & & $\begin{array}{l}\text { Nic Cox (A6) } \\
\text { Renoux Hughes (A9) }\end{array}$ \\
\hline Burocracia & & $\begin{array}{l}\text { Geni Rodio Ribeiro (A5) } \\
\text { Renoux Hughes (A9) }\end{array}$ \\
\hline
\end{tabular}


Por fim, Hughes menciona que a Europa está em crise e quando o mercado passa por esses momentos, dificilmente aposta em produtos diferentes, ou seja, as empresas voltam a comprar produtos básicos, ou seja, produtos que sabe-se que serão vendidos ou produtos que podem ser produzidos em grande escala para que os preços sejam mais baixos. Em função desse contexto ele cita que está difícil transmitir a mensagem da brasilidade. O quadro 18 sintetiza os entraves mencionados pelos entrevistados.

\subsection{Síntese dos resultados do estudo}

A partir da análise dos dados e do cruzamento com os apontamentos identificados na fundamentação teórica, observou-se, na visão dos entrevistados, que o Brasil transmite a imagem de um país com povo caraterizado pela sensualidade (GIRALDI et al., 2011b; MORACE, 2009), pela afetividade e hospitalidade (GIRALDI et al., 2011b; SEBRAE, 2002), pela sua cultura, comida, pelo carnaval (GIRALDI et al., 2011b) e pela vasta gama de manifestações culturais (FINESTRALI; GARRIDO, 2010; SEBRAE, 2002). Uma nação multirracial e miscigenada (FREYRE, 1995; 2009; BASTIDE, 1980; ORTIZ, 2006; SEBRAE, 2002) que, apesar de ter sua economia em um momento de ascensão (GIRALDI $e t$ al., 2011b) e de ter facilidade em se adaptar ao novo (SEBRAE, 2002), apresenta grande desigualdade social (GIRALDI et al., 2011b). Um país que tem como valores: a alegria de viver; a espontaneidade nos relacionamentos humanos; a simplicidade no cotidiano; neutralidade dos produtos (frescor no consumo); a riqueza e a variedade das cores; os sorrisos e a naturalidade do ambiente e das pessoas (MORACE, 2009).

Identificou-se, porém, que no contexto da moda a imagem do Brasil ainda está em construção, em função desse ser um segmento que começou a desenvolver sua identidade após abertura do mercado comercial e da constituição de escolas superiores de moda no final da década de 1980 conforme apontam Braga (2006), Costa (2011) e Pires (2007). Apoiando esses autores, os entrevistados mencionaram que o segmento da moda no Brasil tem poucos anos de história própria e que, por isso, a construção da identidade da moda brasileira é muito recente.

Assim, os entrevistados apontaram que a imagem do Brasil no contexto da moda ainda não é plenamente compreendida pelo mercado internacional, por isso, percebe-se que há necessidade de se intensificar projetos de comunicação da imagem do Brasil no contexto da 
moda no mercado internacional. No entanto, identificou-se que os agentes de mercado que participaram deste estudo entendem o conceito da imagem do Brasil na moda e mencionaram como principais atributos de brasilidade na moda: cores, formas e volumes, o estilo de vida e as estampas. Mencionaram também as representações do Brasil e símbolos nacionais, como atributos importantes, mas menos percebidos e valorizados pelo mercado internacional. Além disso, mencionaram o atributo tecido como valorizado no segmento da moda praia.

No entendimento dos entrevistados, os atributos mais valorizados pelo mercado internacional são: em primeiro lugar cores e estampas e, em segundo lugar (empatado) estilo de vida e formas e volumes. É importante destacar que os entrevistados não mencionaram nenhum novo atributo àqueles identificados na fundamentação teórica.

Pode-se observar, por meio da fala dos entrevistados, que a internacionalização da moda brasileira ainda está em estágio inicial e que os resultados ainda são pouco expressivos. Como discorrido anteriormente, é um processo que começou a ser desenvolvido no começo da década de 2000 e, de acordo com a Abest (2012), desde então a moda nacional tem crescido, mas passa por um momento de profissionalização.

Verificou-se também que os atributos da imagem do país de origem exercem papel importante na inserção e no posicionamento do produto de moda brasileiro no mercado internacional, reforçando os apontamentos de Secani e Jorge (2005) quando citam que a entrada de produtos brasileiros em outros mercados permitiu que o Brasil promovesse o produto com características nacionais e ainda afirmar tais características para o seu próprio povo.

Logo, conforme apontado por diversos entrevistados (item 4.2.2.2), muitas marcas e designers brasileiros estão se apropriando de atributos de brasilidade para posicionar suas marcas no mercado internacional, reforçando assim, os apontamentos de Messias (2009) de que uma dentre as alternativas utilizadas por muitos designers para demarcar suas posições no mercado, encontrou apoio na transposição de referências da cultura brasileira para suas coleções.

No entanto, os entrevistados apontam que a transposição dos atributos da brasilidade para a oferta deve ser realizada com cautela, pois o mercado ofertante de moda brasileira precisa compreender e utilizar, de forma adequada, os atributos que compõem a imagem do Brasil na 
moda para não ofertar produtos com apelo de caricatura.

Quando indagados sobre as formas de diferenciação da oferta no segmento da moda no mercado internacional, os entrevistados mencionaram que a proposta de diferenciação de uma oferta de moda deve envolver: o design, a qualidade, o suporte e serviços e o desenvolvimento de atributos relacionados ao país de origem.

Com isso, os entrevistados destacaram que a imagem do país de origem pode ser uma fonte de vantagem competitiva, mas não deve ser utilizada de forma isolada na oferta, deve fazer parte de um conjunto de elementos distintivos. Além disso, os entrevistados destacaram que a imagem do Brasil no segmento da moda ainda precisa ser compreendida pelo mercado internacional para que se tornar um elemento distintivo da oferta capaz de gerar vantagem competitiva à moda brasileira em transações entre fronteiras.

Os entrevistados também mencionaram diversos entraves que prejudicam a evolução do processo de internacionalização da moda brasileira, conforme pode ser observado no quadro 19 que apresenta os principais achados deste estudo.

\section{Quadro 19 - Principais achados do estudo}

\begin{tabular}{|c|c|c|}
\hline Subdimensão & Aporte teórico & Principais apontamentos dos entrevistados \\
\hline $\begin{array}{l}\text { A imagem } \\
\text { do país de } \\
\text { origem }\end{array}$ & 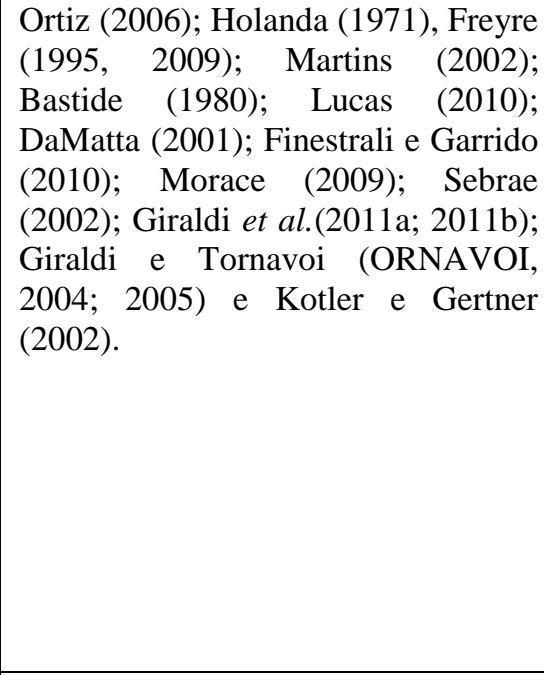 & $\begin{array}{l}\text { - Sensualidade; } \\
\text { - Afetividade e hospitalidade; } \\
\text { - Solidariedade e índole relacional; } \\
\text { - Cultura, comida e carnaval; } \\
\text { - Desigualdade social; } \\
\text { - Natureza, praia, clima e belezas naturais } \\
\text { - Ascensão econômica e produtos } \\
\text { - Vasta gama de manifestações culturais } \\
\text { - Miscigenação de raças } \\
\text { - Valores: alegria de viver; espontaneidade nos } \\
\text { relacionamentos humanos; a simplicidade no } \\
\text { cotidiano; neutralidade dos produtos a riqueza e a } \\
\text { variedade das cores; } \\
\text { - Adaptabilidade e abertura ao novo } \\
\text { - O prestígio das expressões artísticas; } \\
\text { - Jeitinho brasileiro. }\end{array}$ \\
\hline $\begin{array}{l}\text { Identidade } \\
\text { da Moda } \\
\text { Brasileira }\end{array}$ & $\begin{array}{l}\text { Castilho e Garcia (2001); Neira } \\
\text { (2008); Bonadio e Guimarães } \\
\text { (2010); Avelar (2009); Messias } \\
\text { (2009); Braga (2006) e Costa (2011). }\end{array}$ & $\begin{array}{l}\text { - Moda Brasileira é jovem; } \\
\text { - Pouco histórico de moda nacional; } \\
\text { - A identidade da moda brasileira está em processo de } \\
\text { construção. }\end{array}$ \\
\hline $\begin{array}{l}\text { Atributos de } \\
\text { Brasilidade } \\
\text { na Moda }\end{array}$ & $\begin{array}{l}\text { Feghali (2004), Lucas (2010), Avelar } \\
\text { (2009), Neira (2008), Leitão (2009), } \\
\text { Silveira et al. (2009), Freyre (2009), } \\
\text { Morace (2009), Castilho e Garcia }\end{array}$ & $\begin{array}{l}\text { Atributos reconhecidos: } \\
1^{\circ} \text { Cores e estampa (menção dos } 9 \text { entrevistados); } \\
2^{\circ} \text { Estilo de vida e formas e volumes (menção de } 7 \\
\text { entrevistados); }\end{array}$ \\
\hline
\end{tabular}




\begin{tabular}{|c|c|c|}
\hline & $\begin{array}{l}\text { (2001), Braga (2010), Rybalowski } \\
\text { (2008), Aguiar e Caldas (2006), } \\
\text { Centeno (2010), Dener (in DÓRIA, } \\
\text { 1998), Chataignier (2006), Bonadio } \\
\text { e Guimarães (2010) e Apex (2012). }\end{array}$ & $\begin{array}{l}3^{\circ} \text { Tecidos e Representações do Brasil e símbolos } \\
\text { nacionais (menção de } 3 \text { entrevistados); } \\
4^{\text {o }} \text { Matérias primas naturais e aplicações e técnicas } \\
\text { artesanais ( } 1 \text { menção). } \\
\text { Atributos valorizados e utilizados pelos agentes do } \\
\text { segmento: cores, estampas, formas e volumes e o } \\
\text { estilo de vida do brasileiro. }\end{array}$ \\
\hline $\begin{array}{l}\text { A moda } \\
\text { brasileira no } \\
\text { mercado } \\
\text { internacional }\end{array}$ & $\begin{array}{l}\text { Vicente (2009), Abest (2012), Apex } \\
\text { (2012), Abit (2012), Leitão (2009), } \\
\text { Secani e Jorge (2005), Messias } \\
\text { (2009), } \\
\text { Moore et al. (2000), TexBrasil } \\
\text { (2012) e Manetti (2006). }\end{array}$ & $\begin{array}{l}\text { - A inserção da moda brasileira no mercado } \\
\text { internacional ainda está em estágio inicial; } \\
\text { - Há necessidade de se comunicar a imagem do Brasil } \\
\text { no contexto da moda no mercado internacional; } \\
\text { - Atributos da brasilidade são valorizados, mas ainda } \\
\text { não são completamente compreendidos. }\end{array}$ \\
\hline $\begin{array}{l}\text { Formas de } \\
\text { diferenciação } \\
\text { do produto } \\
\text { de moda no } \\
\text { mercado } \\
\text { internacional }\end{array}$ & $\begin{array}{l}\text { Mintzberg (2006), Kotler e Keller } \\
\text { (2006), Zatta et al. (2011), Brïdson } \\
\text { e Evans (2004), Kikuchi e Silva } \\
\text { (2011), Orsato (2006), King e Lenox } \\
\text { (2001), Elkinton (1994), Rocha et al. } \\
\text { (2005), Emerenciano e Pires (2006), } \\
\text { When-Cheng et al. (2011), Danskin } \\
\text { et al. (2005), Rybalowski (2008), } \\
\text { Finestrali e Lapuente (2010); Giraldi } \\
\text { e Tornavoi (2005). }\end{array}$ & $\begin{array}{l}\text { Oferta que combine a distinção por meio do design, da } \\
\text { qualidade, do suporte e serviços e imagem do país de } \\
\text { origem. } \\
\text { A imagem do país do Brasil é uma forma de distinção } \\
\text { relevante, mas deve ser trabalhada junto a outras } \\
\text { formas de distinção. } \\
\text { A imagem do Brasil no contexto da moda precisa ainda } \\
\text { ser melhor compreendida pelo mercado para tornar-se } \\
\text { fonte de vantagem competitiva. } \\
\text { Ofertantes devem atentar a forma como se apropriam } \\
\text { dos atributos da brasilidade para não ofertarem } \\
\text { produtos caricatos. }\end{array}$ \\
\hline $\begin{array}{l}\text { Entraves à } \\
\text { inserção da } \\
\text { Moda } \\
\text { Brasileira no } \\
\text { mercado } \\
\text { Internacional }\end{array}$ & $\begin{array}{l}\text { Manetti (2006), Filho (2011 in IEMI, } \\
\text { 2011), Zatta (et al., 2011), Bruno et } \\
\text { al. (2009) e Costa e Rocha (2009). }\end{array}$ & $\begin{array}{l}\text { - Elevada carga tributária; } \\
\text { - Juros altos; } \\
\text { - Custo dos encargos sociais; } \\
\text { - Câmbio; } \\
\text { - Crescimento da entrada de produtos importados; } \\
\text { - Dificuldade de acessar matéria prima de qualidade; } \\
\text { - Dificuldade de acesso a financiamentos; } \\
\text { - Domínio do mercado por grupos Italianos, Franceses, } \\
\text { Ingleses e recentemente Americanos; } \\
\text { - Concorrência Asiática; } \\
\text { - Resquício de reprodução de coleções lançadas na } \\
\text { Europa; } \\
\text { - Falta de profissionalismo na formação de preço por } \\
\text { parte do ofertante - produtos com preços elevados; } \\
\text { - Mentalidade do empresário brasileiro; infraestrutura } \\
\text { precária (logística, portos, aeroportos, matriz } \\
\text { energética e educação); } \\
\text { - Escassez de mão de obra qualificada; } \\
\text { - Rotatividade dos funcionários nas empresas; } \\
\text { - Deficiência na costura; } \\
\text { - Falta de consistência do estilo entre coleções; } \\
\text { - Moda brasileira não desenvolve produtos de inverno } \\
\text { adaptados para o mercado internacional } \\
\text { - Burocracia. }\end{array}$ \\
\hline
\end{tabular}

A partir do estudo empírico pode-se responder a Q1 proposta na fase de campo - Quais os atributos que compõem a imagem país de origem no segmento da moda brasileira? 
Compreendeu-se que os atributos da imagem do Brasil no segmento da moda são os mesmos identificados na literatura.

Por meio da análise dos dados da etapa empírica pode-se responder também à Q2 - Quais os atributos da imagem país de origem na moda brasileira que são reconhecidos, valorizados e utilizados pelos agentes do segmento? De acordo com os entrevistados inferiu-se que os atributos reconhecidos, valorizados e utilizados pelos agentes do segmento são, em primeiro lugar, cores e estampas; seguidos de: estilo de vida e formas e volumes; depois por: representações do Brasil e símbolos nacionais e tecidos. Os atributos: matérias primas naturais e aplicações e técnicas artesanais foram mencionados somente uma vez. 


\section{CONSIDERAÇÕES FINAIS}

O estudo foi desenvolvido no contexto da moda brasileira e teve como objetivo geral compreender quais são os atributos da imagem do país de origem que representam fonte de vantagem competitiva no mercado internacional. Para responder ao problema de pesquisa proposto e atingir o objetivo delineado, levantou-se dados secundários e primários que permitiram a autora tecer considerações sobre o tema.

A revisão da literatura e a pesquisa de campo permitiram a compreensão sobre a imagem do Brasil, assim como aprofundou o entendimento sobre o constructo da imagem do país de origem no contexto da moda brasileira. Logo, o estudo trouxe conhecimento a cerca da brasilidade na moda apresentando os seguintes atributos como componentes da imagem do país de origem no segmento da moda brasileira: cores; estampas; estilo de vida; formas e volumes; tecidos; representações do Brasil e símbolos nacionais; matérias primas naturais e aplicações e técnicas artesanais. Cabe destacar que nenhum novo atributo foi mencionado na fase de campo.

Dentre os elementos de brasilidade mencionados verificou-se que os atributos: formas e volumes, cores, estampas e estilo de vida são os componentes mais reconhecidos, valorizados e utilizados pelos agentes de mercado da moda. Os atributos tecidos e representações do Brasil e símbolos nacionais também são valorizados e utilizados, porém não tanto quanto os mencionados anteriormente.

Pode-se verificar, porém, que a história da moda brasileira, a construção da sua identidade e seu processo de inserção em mercados internacionais são recentes. Como visto, a moda brasileira começou a desenvolver sua identidade a partir da abertura comercial (final da década de 1980) e o movimento de internacionalização começou no final da década de 1990, por isso, o processo de internacionalização da moda brasileira ainda está em estágio inicial. Em função dessas características, o mercado internacional ainda não compreende a imagem do Brasil no contexto da moda.

Nesse sentido, observou-se que a imagem do país de origem na moda brasileira poderá representar uma fonte de vantagem competitiva a partir do momento em que os agentes de oferta e de apoio à moda brasileira conseguirem transmitir uma imagem da moda brasileira 
que seja compreendida pelo mercado internacional. No entanto, esse não é um trabalho simples de ser realizado, dado que o Brasil é um país multifacetado, com muita diversidade em função da sua história, com a miscigenação de raças (Índios, Africanos, Portugueses e Imigrantes) e cultura gerada a partir dessa mistura que pode ser utilizada como repertório criativo. Viu-se também que esforços nesse sentido estão sendo realizados por associações do setor e governo, como Abit, Abest e Apex, por meio de projetos como o TexBrasil.

Observou-se também que o mercado internacional demanda ofertas que sejam diferenciadas com base em mais de um elemento distintivo, ou seja, a oferta deve ser composta por: design, qualidade, suporte e serviços e o desenvolvimento de atributos relacionados ao país de origem, sempre com foco no consumidor global. A distinção por sustentabilidade e inovação também foram mencionadas como importantes, porém não tanto quanto as primeiramente citadas. A diferenciação por imagem da marca também foi apontada como relevante, porém é uma forma de diferenciação pouco viável para marcas brasileiras desenvolverem entre fronteiras, uma vez que demanda investimento financeiro elevado e por ser um trabalho de médio a longo prazo.

Assim, o estudo apontou para a importância da utilização de atributos da imagem do país de origem como elemento distintivo respeitando os anseios do consumidor global, mas ficou evidente que essa não é a única fonte de vantagem competitiva, por isso não deve ser utilizada de forma isolada. Além disso, observou-se que os agentes ofertantes devem se apropriar dos atributos da brasilidade com cautela para que a oferta não seja caricata. Nesse sentido, recomendam-se estudos futuros multidisciplinares, com pesquisadores de administração e pesquisadores de design, para verificar as formas de transposição da brasilidade para a moda que não tornem a oferta com apelo artesanal, carregada, com atributos em demasia ou caricata. $\mathrm{O}$ estudo de campo evidenciou que não há necessidade de se utilizar sempre todos os atributos, mas que devem ser utilizados com parcimônia e com bom gosto.

O estudo também permitiu identificar entraves que prejudicam a inserção da moda brasileira no mercado internacional conforme apontado no aporte teórico e ainda identificou outras barreiras que dificultam esse processo que não foram mencionados na literatura. Com isso, sugerem-se estudos que busquem compreender o processo de internacionalização da moda brasileira e as barreiras enfrentadas pelas marcas, de modo que, providas dos resultados as empresas e associações do segmento possam desenvolver ações para melhorar o processo de 
inserção da moda brasileira no mercado internacional.

A partir dos achados, considera-se que a Brasilidade na moda pode tornar-se fonte de vantagem competitiva a partir do momento em que o Brasil conseguir construir e comunicar sua imagem no contexto da moda. No âmbito deste estudo, os atributos da imagem do país de origem que representam fonte de vantagem competitiva são: estilo de vida, formas e volumes, cores e estampas. Lembrando que os designers devem respeitar as demandas do consumidor internacional.

Logo, o estudo traz contribuições ao apontar atributos da brasilidade que podem ser fonte de vantagem competitiva, dentro dos parâmetros definidos, podendo os atores do segmento estudado fazerem uso de tal conhecimento. A partir dos resultados obtidos, recomendam-se estudos futuros de cunho quantitativo para validar os achados quanto aos atributos da brasilidade que podem representar fonte de vantagem competitiva no mercado internacional e à composição da oferta diferenciada. Sugerem-se, também, estudos com consumidores finais, por meio de experimentos, para verificar se estes compreendem os atributos de brasilidade na moda e se os valorizam. O estudo também identifica fatores que dificultam a internacionalização da moda brasileira que poderiam ser melhor desenvolvidos pelo governo e por agentes do setor.

Com relação às implicações conceituais, o estudo contribui com o constructo de brasilidade na moda, ao sugerir atributos que compõem a imagem do país na moda. Assim, contribui ao relacionar variáveis pouco estudadas, ou seja, imagem do país de origem, brasilidade, fonte de vantagem competitiva, diferenciação, mercado internacional e segmento da moda.

A pesquisa empírica conduziu a informações relevantes e auxiliou a cumprir o objetivo do estudo. É necessário, contudo, reconhecer que a natureza exploratória, a abordagem qualitativa e os métodos adotados neste estudo apresentam limitações. Sabe-se que em pesquisas exploratórias, o principal intuito é descobrir explicações possíveis para o fato, as quais devem ser posteriormente averiguadas por meio de estudos quantitativos devido à subjetividade das pesquisas qualitativas, que se apoiam nas crenças, predisposições e nas expectativas do pesquisador com relação ao tema.

Por isso, a primeira limitação do estudo refere-se ao viés do pesquisador e seus pré-conceitos 
ao realizar a entrevista semiestruturada e analisar os dados, limitação que foi reduzida por meio de intensa pesquisa documental e revisão da literatura.

Outra limitação refere-se a uma das características da abordagem qualitativa, no tocante a amostragem por conveniência. Ou seja, a seleção dos entrevistados respeitou requisitos abordados no capítulo de procedimentos metodológicos, mas a realização das entrevistas dependeu do interesse e da autorização dos agentes de mercado em participar do estudo, em disponibilizar tempo, bem como do acesso à pesquisadora de informações relevantes para análise. Com isso, não se pode generalizar os dados que foram analisados nesta investigação, logo as sugestões do estudo limitam-se ao contexto pesquisado. 


\section{REFERÊNCIAS}

ASSOCIAÇÃO BRASILIERA DE ESTILISTAS - ABEST. Disponível em: <http://www.abest.com.br/2009/abest.php?lang=pt>. Acesso em: 02/03/2012.

ASSOCIAÇÃO BRASILSEIRA DA INDÚSTRIA TÊXTIL E DE CONFECÇÃO - ABIT, Perfil do Setor. Disponível em: <http://www.abit.org.br/site/navegacao.asp?id_menu=1\&id_sub=4\&idioma=PT $>$. Acesso em: 20/03/2012.

AFONSO, I. Moda: Colegiado setorial avança na construção de plano cultural da moda. Site do Ministério da Cultura - Minc. Disponível em: <http://www.cultura.gov.br/site/2010/11/23/moda-2/>. Acesso em: 12 Jan. 2011.

AGRAWAL, J.; KAMAKURA, W. A. Country of origin: A competitive Advantage? International Journal of Research in Marketing. Vol. 16, p. 255-267, 1999.

AGUIAR, I.; CALDAS, A. A Influência da Cultura Indígena na Indumentária. In: COLÓQUIO NACIONAL DE MODA, 2., de 03 - 06 out. 2006, Salvador. Anais eletrônicos.... Salvador: Colóquio Nacional de Moda, 2006. CD-ROOM.

AL-SULAITI, K.; BAKER, M. J. Country of origin effects: a literature review. Marketing Intelligence \& Planning. Vol. 16, no. 3, p. 150-190, 1998.

ANSOFF, H Igor. A Nova estratégia Empresarial. São Paulo: Atlas, 1990.

AGENCIA BRASILEIRA DE PROMOÇÃO DE EXPORTAÇÃO E INVESTIMENTOS APEX, Exportação, setores, moda, 2012. Disponível em: <http://www.apexbrasil.com.br/portal/> . Acesso em: 18/04/2012.

Texbrasil, 10 anos: internacionalização da moda brasileira. In: IMEI- Instituto de Estudos e Marketing Industrial. Relatório Setorial da Indústria Têxtil Brasileira, São Paulo, Vol. 11, no. 11, Set. 2011.

ARMONI, A.. In: COBRA, M. Marketing e Moda. 1a . ed. São Paulo: Senac, 2007.

AVELAR, S. Moda, globalização e novas tecnologias. São Paulo: Estação das Letras de Cores, 2009.

BARNEY, J. Firm Resources and Sustained Competitive Advantage. Journal of 
Management. Vol. 17, no. 1, p. 99 - 120, 1991.

BARNEY, J. B.; HESTERLY, W.S. Administração Estratégica e Vantagem Competitiva. São Paulo: Pearson Prentice Hall, 2007.

BASTIDE, R. Brasil Terra de Contrastes. São Paulo - Rio de Janeiro: Diefel/difusão editorial S.A., 1980.

BAUER, M.; AARTS, B. A construção do corpus: um princípio para a coleta de dados qualitativos. In: BAUER, M.; GASKELL, G. (ed.). Pesquisa qualitativa com texto, imagem e som: um guia prático. Petrópolis: Vozes, 2002.

BONADIO, M. C.; GUIMARÃES, M. E. A. Alceu Penna e a construção de um estilo brasileiro: modas e figurinos. Horizontes Antropológicos, Porto Alegre, ano 16, n. 33, p. 145-175, Jan./Jun. 2010.

BONADIO, M. C. A Produção Acadêmica sobre Moda na Pós-graduação Stricto Sensu no Brasil. Iara - revista de Moda, Cultura e Arte. São Paulo, vol. 3, no. 3, p. 50-146, dez. 2010.

BRAGA, J. História da Moda: uma narrativa. São Paulo: Ed. Anhembi Morumbi, 2004.

Reflexões sobre moda, vol.1. São Paulo: ed. Anhembi Morumbi, 2005.

Reflexões sobre moda, vol. III. 2ed. São Paulo: Ed. Anhembi Morumbi, 2008.

Herança. In: B+ Inspiração Brasil verão 2011. ABEST, jun 2010.

BRÏDSON, K.; EVANS, J. The secret to fashion advantage is brand orientation. International Journal of Retail \& Distribution Management. Vol. 32, n. 8, p. 403-411, 2004.

BRUNO, F. da S.; FILIPECKI, A. T. P.; JÚNIOR, E. S. Globalização do setor têxtil e de confecção brasileiro: a busca pelo controle de ativos escassos de conhecimento. Revista Espacios. Vol. 30, n. 1, 2009.

BURITY, J. A. Mudança Cultural, mudança religiosa e mudança política. In: BURITY, J. A (org.). Cultura e Identidade: perspectivas interdisciplinares. Rio de Janeiro: DP\&A, 2002. 
CALDAS, M. P. Conceptualizing Brazilian Multiple and Fluid Cultural Profiles. Management Research: The Journal of the Iberoamerican Academy of Management. Vol. 4, Iss: 3, p. 169-180, 2006.

CATER, T. The relevance of four schools of thought on the sources of a firm's competitive advantage: a case of Slovenian firms. Economic and Business Review. Vol. 5, no. 4, p. 309332, 2003.

CASTILHO, K.; GARCIA, C. (orgs). Moda Brasil - fragmentos de um vestir tropical. São Paulo: Anhembi Morumbi, 2001.

CAVAlHEIRO, W. Prefácio. In: CASTILHO, K.; GARCIA, C. (orgs). Moda Brasil fragmentos de um vestir tropical. São Paulo: Anhembi Morumbi, 2001.

CENTENO, G. C. O Brasil na moda: novas representações do consumo e promoção da brasilidade. In: COLÓQUIO NACIONAL DE MODA, 6., 12-15 set., 2010. São Paulo. Anais Eletrônicos... São Paulo: Colóquio de Moda, 2010. CD-ROOM.

CHATAIGNIER, G. Fio a Fio - Tecidos, Moda e Linguagem. São Paulo: Estação das Letras, 2006.

. História da Moda no Brasil. São Paulo: Estação das Letras e Cores, 2010.

CAMPOMAR, M. C. Marketing Business to Business. In: OLIVEIRA, B. (Org.). Gestão de Marketing. São Paulo: Pearson Prentice Hall, 2012.

COSTA, A. C. R. da; ROCHA, R. P. da. Panorama da Cadeia Têxtil e de Confecções e a Questão da Inovação. BNDES Setorial, Rio de Janeiro, n. 29, p. 159-202, mar. 2009.

COSTA, E.F. Comprador de Moda. São Paulo: Ed. Senac, 2011.

DALPRA, P. (org.). DNA Brasil - Tendências e conceitos emergentes para as cinco regiões brasileiras. São Paulo: Estação das Letras e Cores, 2009.

DAMATTA, R. O que faz o brasil, Brasil? 12a ed. Rio de Janeiro: Editora Rocco, 2001.

DANSKIN, P.; ENGLIS, B. G.; SOLOMON, M. R.; GOLDSMITH, M.; DAVEY, J. Knowledge management as competitive advantage: lessons from the textile and apparel value chain. Journal of Knowledge Management.Vol. 9, no. 2, p. 91-102, 2005. 
DAY, G. S.; WENSLEY, R. Assessing Advantage: A framework for diagnosing competitive superiority. Journal of Marketing. Vol. 52, no. 2, p. 1-20, 1988.

D'ALMEIDA, T. Não basta desfilar, tem que vender: (des)encontros entre moda e mercado. Dobras. Vol. 2, no. 2, fev. 2008.

DÓRIA, C. Bordado da fama, uma biografia de Dener. Senac 1998.

DURAND, J. C.. Moda, Luxo e Economia. São Paulo; Babel Cultural, 1988.

ELKINGTON, J. Towards the Sustainable Corporation: Win-Win-Win Business Strategies for Sustainable Development. California Management Review. P. 90-100, Winter 1994.

EMERENCIANO, J. W.; PIRES, D. B. O Design como Estratégia para a Sustentabilidade de Produtos de Moda. In: COLÓQUIO NACIONAL DE MODA, 2., de 03 - 06 out. 2006, Salvador. Anais Eletrônicos.... Salvador: Colóquio Nacional de Moda, 2006. CD-ROOM.

EUROMONITOR. Brazil: Country Profile. Março de 2012. Disponível em: <http://www.portal.euromonitor.com/Portal/Pages/Search/SearchResultsList.aspx>. Acessado em: 09/05/2012.

FEGHALI, M. K. As engrenagens da moda. Rio de Janeiro: Ed. Senac Rio, 2004.

Batendo perna: forças que influenciam o comportamento do consumidor de moda. In: FEGHALI, M.; SCHMID, E. (orgs.). O Ciclo da Moda. 1ª ed. Rio de Janeiro: Senac Rio, 2008.

FILHO, A. D. Editoral ABIT. In: IMEI- Instituto de Estudos e Marketing Industrial. Relatório Setorial da Indústria Têxtil Brasileira, São Paulo, Vol. 11, no. 11, Set. 2011.

FINESTRALI, M.; GARRIDO, I. L. Uso de referências da identidade cultural brasileira no marketing internacional de produtos e marcas de luxo. Revista de Administração FACES Journal. Vol. 9, no. 3, p. 57-76, jul/set. 2010.

FLICK, U. Introdução à Pesquisa Qualitativa. 3. Ed. Porto Alegre: Artmed, 2009.

FREYRE, G. Casa-grande \& Senzala: formação da família brasileira sob o regime da economia patriarcal. 30a ed. Rio de Janeiro: Record, 1995. 
. Modos de Homem \& Modas de Mulher. $2^{\text {a }}$ Ed. São Paulo: Global, 2009.

FRINGS, G. S. Fashion: From Concept to Costumer. $7^{\text {a }}$.ed. Upper Saddle River: Pearson Prentice Hall, 2001.

GILL, R. Análise de Discurso. In: A construção do corpus: um princípio para a coleta de dados qualitativos. In: BAUER, M.; GASKELL, G. (ed.). Pesquisa qualitativa com texto, imagem e som: um guia prático. Petrópolis: Vozes, 2002.

GIRALDI, J. M. E.; TORNAVOI, de C. D. A Importância da imagem do País de Origem na Internacionalização de Produtos Brasileiros. Caderno de Pesquisas em Administração. São Paulo, vol. 11, no. 4, p. 43-57, out/dez. 2004.

O uso da informação sobre o país de origem como fonte de vantagem competitiva nos mercados externos. Revista de Administração Mackenzie. Vol. 6, no. 1, p. 129-156, 2005 .

GIRALDI, J. M. E.; IKEDA, A. A., CAMPOMAR, M. C. Reasons for country image evaluation: A study on China image from a Brazilian perspective. Database Marketing \& Customer Strategy Management. Vol. 18, no. 2, p. 97-107, 2011a.

GIRALDI, J. M. E.; GIRALDI, I. M. E.; SCADUTO; A. A. Brazil's image as social representation process. African Journal of Business Management. Vol. 5), p. 8821-8831, $2011 b$.

GODOI, C. K.; MATTOS, P. L. C. L. Entrevista qualitativa: instrumento de pesquisa e evento dialógico. In: GODOI, C. K.; BANDEIRA-DE-MELLO, R.; DA SILVA, A. B (org.). Pesquisa qualitativa em estudos organizacionais: paradigmas, estratégias e métodos. São Paulo: Saraiva, 2006.

GOLDSMITH, R. E.; FLYNN, L. R.; CLARK, R. A. Materialistic, brand engaged and status consuming consumers and clothing behaviors. Journal of Fashion Marketing and Management. Vol. 16, no. 1, p. 102-119, 2012.

GÜRHAN-CANLI; Z.; MAHESWARAN, D. Cultural Variations in Country of Origin Effects. Journal of Marketing Research. Vol. 37, no. 3, p. 309-317, 2000.

HANSEN, K. T. The World in Dress: Anthropological Perspectives on Clothing, Fashion, and Culture. Annual Review of Anthopology. Vol. 33, p. 369-392, 2004. 
HOLANDA, S. B. De. Raízes do Brasil. 6ª ed. Rio de Janeiro: José Olympio, 1971.

IMEI- Instituto de Estudos e Marketing Industrial. Relatório Setorial da Indústria Têxtil Brasileira, São Paulo, Vol. 11, no. 11, Set. 2011.

KIKUCHI, C. Y.; SILVA, T. L. Arte, design e sustentabilidade no processo de diferenciação dos produtos de moda. In: COLÓQUIO NACIONAL DE MODA , 7., 11-14 set. 2011, Maringá. Anais Eletrêonicos... Maringá: Colóquio de Moda, 2011. CD-ROOM.

KING; A. A.; LENOX, M. J. Does it really pay to be green? An empirical study of firm environmental and financial performance. Journal of Industrial Ecology. Vol. 5, no. 1, p. 105-116, 2001.

KONIG, R. Sociologie de La mode. Paris: Petite Bibliothèque Payot, 1969.

KOTLER, P.; KELlER, K. L. Administração de Marketing. 12a. ed. São Paulo: Pearson Prentice Hall, 2006.

KOTLER, P.; GERTNER, D. Country as brand, product, and beyond: a place marketing and brand management perspective. Journal of Brand Management. Vol. 9, no. 4/5,p. 249-261, April 2002.

LAGE, S. Palestra Comportamento do Consumidor Contemporâneo. São Paulo, FIA, 2011.

LAMBIN, J. J. Marketing Estratégico. 4a. Ed, Lisboa: McGraw-Hill, 2000.

LAW, K. M.; ZHANG, Z-M.; LEUNG, C-S. Fashion change and fashion consumption: the chaotic perspective. Journal of Fashion Marketing and Management. Vol. 8, no. 4, pp. 362-374, 2004.

LEITÃO, D. K. O Brasil é uma paisagem: moda, nação, identidades e outras invenções. Iara - revista de Moda, Cultura e Arte. São Paulo, vol. 2, no. 2, p. 139-163, out/dez. 2009.

LIPOVETSKY, G. O império do efêmero: a moda e seu destino nas sociedades modernas. São Paulo: Companhia das Letras, 2009.

LUCAS, M. C de L. Que rua é essa? Um passeio (não registrado) pelo vestir mestiço brasileiro. Iara - Revista de Moda, Cultura e Arte. São Paulo, vol. 3, no. 1, Ago. 2010. 
MATTAR, F. N. Pesquisa de Marketing. $4^{\text {a }}$ ed. São Paulo: Atlas, 2007.

MARCONI, M. A.; LAKATOS, E.M. Fundamentos da metodologia científica. 7 ed. São Paulo: Atlas, 2010.

MARTINS, P. H. Cultura autoritária e aventura da brasilidade. In: BURITY, J. A (org.). Cultura e Identidade: perspectivas interdisciplinares. Rio de Janeiro: DP\&A, 2002.

MDIC - Ministério do Desenvolvimento, Indústria e Comércio Exterior. Sistema Moda Brasil será lançado durante o São Paulo Fashion Week, em 19/06/2009. Disponível em: $<$ http://www.mdic.gov.br/sitio/interna/noticia.php?area=2\&noticia=9130>. Acesso em: 28/03/2012.

MENATTI, A. Oportunidade no mercado internacional para empresas brasileiras dentro do segmento da moda. In: COLÓQUIO NACIONAL DE MODA, 2., de 03 - 06 out. 2006, Salvador. Anais Eletrônicos.... Salvador: Colóquio Nacional de Moda, 2006. CD-ROOM.

MESSIAS, E. M. O campo da moda no Brasil e os agentes da brasilidade. In: COLÓQUIO NACIONAL DE MODA, 4., 29 set. a 2 de out. 2008, Novo Hamburgo. Anais Eletrônicos... Novo Hamburgo: Colóquio de Moda, 2008. CD-ROOM.

Brasilidade como estratégia de construção de identidade nas coleções da marca Fórum. In: COLÓQUIO NACIONAL DE MODA, 5., 27-30 set. 2009, Recife. Anais Eletrônicos... Recife: Colóquio de Moda, 2009. CD-ROOM.

MOORE, C. M.; FERNIE, J.; BURT, S. Brands without boundaries: The internationalization of the designer retailer's brand. European Journal of Marketing. Vol. 34, no. 8, p. 919937, 2000.

MORACE, F. A globalização e o futuro brasileiro. In: DALPRA, P. (org.). DNA Brasil: Tendências e conceitos emergentes para as cinco regiões brasileiras. São Paulo: Estação das Letras e Cores, 2009.

MINTZBERG, H. Estratégias Genéricas. In: MINTZBERG, H; LAMPEL, J; QUINN, J.B; GHOSHAL, S. O Processo da Estratégia - Conceitos, Contextos e Casos selecionados. Porto Alegre: Bookman, 2006.

NACIF, MCV. O moda como princípio de leitura do mundo. In: ASSOCIAÇÂO NACIONAL DE HISTÓRIA, 14., 15 a 20 jul. 2007, São Leopoldo. Anais... São Leopoldo: Associação Nacional de História, p. 1-10, 2007. 
NADAFF, Ana. Moda cearense: uma concha de retalhos. In: CASTILHO, K.; GARCIA, C. (orgs). Moda Brasil: fragmentos de um vestir tropical. São Paulo: Anhembi Morumbi, 2001.

NEIRA, Luz Garcia. A invenção da moda brasileira. Caligrama - Revista de estudos e pesquisas em linguagem e mídia. Vol. 4, no 1, Jan/Abr. 2008.

ORSATO, R. J. Competitive Environmental Strategies: When does it pay to be Green? California Management Review. Vol. 48, no. 2, p. 127-143, winter 2006.

ORTIZ, R. Cultura brasileira e identidade nacional. $5^{\text {a }}$ ed. São Paulo: Brasiliense, 2006.

PIRES, D. B. Design de moda: uma nova cultura. Revista Dobras. Vol. 1, no. 1, out. 2007.

PORTER, M. E. Vantagem Competitiva: Criando e sustentando um desempenho superior. Rio de Janeiro: Elsevier, 1989.

PORTER. A Vantagem Competitiva das nações. Rio Janeiro: Campus, 1999.

RECH, S. R. Moda: por um fio de qualidade. Florianópolis: UDESC, 2002.

Estrutura da Cadeia Produtiva de Moda. Modapalavra e-períodico. Ano 1, n.1, p. 7 20, jan-jul 2008.

ROCHA, M. A.; HAMMOND, L.; HAWKINS, D. Age, gender and national factors in fashion consumption. Journal of Fashion Marketing and Management. Vol. 9, no. 4, p. 380-390, 2005.

ROTH, K.; DIAMANTOPOULOS, A. Advancing the country image construct. Journal of Business Research. Vol. 62, p. 726-740, 2009.

RYBALOWSKI, T. M. Detalhes tão pequenos. In: FEGHALI, M.; SCHMID, E. (orgs.). O Ciclo da Moda. $1^{\text {a }}$. ed. Rio de Janeiro: Senac Rio, 2008.

SABRÁ, F. G. C. Potencialidades do design de moda brasileiro para a internacionalização. In: COLÓQUIO DE MODA, 6., 12 - 15 set. 2010, São Paulo. Anais Eletrônicos... São Paulo: Colóquio de Moda, 2010. CD-ROOM.

SAES, M.S.M. Diferenciação e apropriação da quase-renda na agricultura: a cafeicultura de pequena escala. São Paulo, 2008. Tese (Livre Docência em Administração) - Programa de Pós Graduação em Administração, Faculdade de Economia, Administração e 
Contabilidade da Universidade de São Paulo.

SAMPIERI, R. H.; COLLADO, C. F.; LUCIO, P. B. Metodologia de pesquisa. 3.ed. São Paulo: McGraw-Hill. 2006.

SEBRAE/NA. Cara Brasileira: a brasilidade nos negócios - um caminho para o "made in Brazil". Brasília: SEBRAE NACIONAL, 2002. Disponível em: <http://www.iets.org.br/biblioteca/Cara_brasileira.pdf>. Acesso em: 06/04/2012.

SCHEMES, C. Alceu Penna e a moda brasileira. In: COLÓQUIO DE MODA, 4., 29 set. a 2 de out. 2008, Novo Hamburgo. Anais... Novo Hamburgo: Colóquio de Moda, 2008.

SCHOOLER, R. D. Product Bias in the Central American Common Market. Journal of Marketing Research. Vol.2, p. 394-97, November, 1965.

SECANI, A. V.; JORGE, L. B. Identidade Nacional: a moda e a imagem do Brasil. In: COLÓQUIO NACIONAL DE MODA, 1., 14-16 set. 2005, Ribeirão Preto. Anais Eletrônicos... Ribeirão Preto: Colóquio Nacional de Moda, 2005. CD-ROOM.

SCHWARZ, R. Nacional por subtração. In: SCHWARZ, R. Que horas são? Ensaios. São Paulo: Companhia das Letras, 1987.

SHIM, S.; BICKLE, M. C. Benefit segments of the female apparel market: psychographics, shopping orientation, and demographics. Clothing \& Textiles Research Journal. Vol. 12, no. 2, p. 1-12, 1994.

SILVEIRA, C. G.; PINHEIRO, O. J.; GOYA, C. R. Caupé Jóias - Projeto de Pesquisa em Design de Joalheria: da Brasilidade à Sustentabilidade. In: CONGRESSO INTERNACIONAL DE PESQUISA EM DESIGN - CIPED, 5., 10-12 de out. 2009, Bauru. Anais... Bauru: V CIPED, 2009.

SIMAI, S. Jeans and Identity for sale: The case of Brazil. E-Journal of American Studies in Hungary. Vol. 7, no. 1, Spring 2011.

TEXBRASIL - PROGRAMA DE EXPORTAÇÃO DA INDÚSTRIA DA MODA BRASILEIRA. Apex-Brasil e ABIT renovam convênio do Texbrasil. Em16/03/2012. Disponível em: <http://www.texbrasil.com.br/texbrasil/NoticiaImprDet.aspx ? NoticiaDetId=835\&NoticiaId=6 20>. Acesso em: 19/03/2012.

USUNIER, J. C. Relevance in business research: the case of country-of-origin research in 
marketing. European Management Review. No. 3, p. 60-73, 2006.

VICENTE, D. P. Criação e desenvolvimento de produtos em empresas brasileiras de moda internacionalizadas: um estudo multicasos. Ribeirão Preto, 2009. Dissertação (Mestrado em Administração) - Programa de Pós Graduação em Administração de Empresas, Faculdade de Administração e Contabilidade de Ribeirão Preto da Universidade de São Paulo.

VILLAÇA, N. Brasil: da identidade à marca. Revista FAMECOS. Porto Alegre, no. 33, pp 61-65, Ago., 2007.

ZATTA, A. M.; CRISHNA, L.; MENEZES, M. dos S. A competitividade da indústria de moda brasileira no cenário internacional com ênfase no design e identidade nacional. In: COLÓQUIO DE MODA, 7., 11-14 de set. 2011, Maringá. Anais Eletrônicos... Maringá: Colóquio de Moda, 2011. CD-ROOM.

WANG, C. L.; LI; D.; BARNES, B. R.; AHN, J. Country image, product image and consumer intention: Evidence from an emerging economy. International Business Review. No. 911, 2011.

WEN-CHENG, W.; CHIEN-HUNG, L.; YING-CHIEN, C. Types of Competitive Advantage and Analysis. International Journal of Business and Management. Vol. 6, no. 5, p. 100104, May 2011.

TOLEDO, G. L.; ANSELMO, E. Estratégia de Crescimento e Estratégia Competitiva- um estudo de caso sobre a evolução dos conceitos em uma empresa metalúrgica. In: SEMINÁRIO EM ADMINISTRAÇÃO - SemeAd, 6., 2003, São Paulo. Anais... São Paulo: SEMEAD, 2003. 


\section{APÊNDICES}

\section{APÊNDICE 1 - ROTEIRO DE ENTREVISTA COM AGENTES DE APOIO}

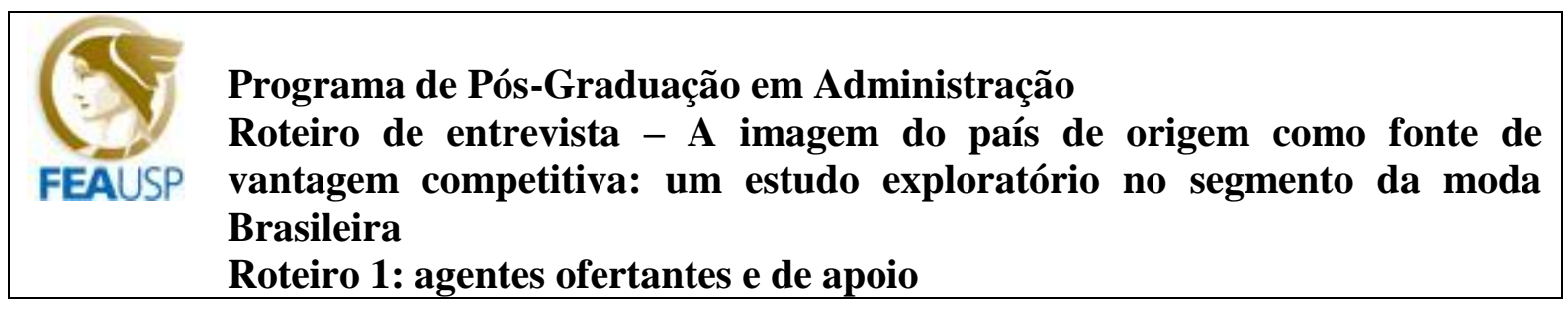

Data: $/ 2012$

Local:

\section{Caracterizacão do ofertante:}

Nome:

Formação:

Área de atuação:

Empresa em que trabalha:

- Há quanto tempo trabalha na área de moda?

- Há quanto tempo realiza sua atual função?

- Conte um pouco sobre sua trajetória no segmento:

\section{Diferenciacão de produto de moda:}

- Quais são os elementos que o mercado internacional está buscando no produto de moda?

- Para você, um produto de moda diferenciado é um produto que apresenta quais características?

\section{Compreensão sobre os atributos que compõem o conceito de Brasilidade na Moda:}

- Para você, o que é a moda brasileira?

- Você acredita que a moda brasileira tem uma identidade? Qual a identidade da moda brasileira?

- O que você entende por elementos de brasilidade? 
- Quais são os elementos que compõem a brasilidade na moda?

- Quais destes elementos você acredita que estão sendo utilizados pelos designers e por quais motivos?

\section{Brasilidade na Moda e diferenciação:}

- De que modo o produto de moda brasileira se diferencia no mercado internacional?

I

- Quais elementos são os mais reconhecidos pelo mercado internacional? Por quê?

- Quais elementos são mais valorizados pelo mercado internacional, em termos de retorno financeiro/econômico (\$\$)? Por quê?

- Os aspectos de brasilidade na moda podem representar fonte de vantagem competitiva no mercado internacional? Por quais motivos?

- Cite uma palavra para expressar a moda brasileira:

- Outros comentários:

Por favor, indique por meio de uma nota, o grau de concordância ou discordância com relação às afirmações a seguir (sendo 1 discordo completamente e 5 concordo completamente): 


\begin{tabular}{|l|l|l|l|l|l|}
\hline $\begin{array}{l}\text { Os seguintes elementos } \\
\text { são característicos da } \\
\text { Brasilidade na moda }\end{array}$ & $\begin{array}{c}1 \\
\text { Discordo } \\
\text { completamente }\end{array}$ & 2 & 3 & 4 & $\begin{array}{c}5 \\
\text { Concordo } \\
\text { completamente }\end{array}$ \\
\hline Estilo de vida - life style & & & & & \\
\hline $\begin{array}{l}\text { Representações do Brasil } \\
\text { e símbolos nacionais }\end{array}$ & & & & & \\
\hline Cores & & & & & \\
\hline Matérias Primas Naturais & & & & & \\
\hline $\begin{array}{l}\text { Aplicações e Técnicas } \\
\text { artesanais }\end{array}$ & & & & & \\
\hline Tecidos & & & & & \\
\hline Estampa & & & & & \\
\hline Formas e volumes & & & & \\
\hline
\end{tabular}

\begin{tabular}{|l|l|l|l|l|l|}
\hline $\begin{array}{l}\text { Os seguintes elementos } \\
\text { da Brasilidade na moda } \\
\text { são valorizados pelo } \\
\text { mercado consumidor } \\
\text { internacional }\end{array}$ & $\begin{array}{c}1 \\
\text { Discordo } \\
\text { completamente }\end{array}$ & & 2 & 3 & \multicolumn{1}{c|}{$\begin{array}{c}\text { Concordo } \\
\text { completamente }\end{array}$} \\
\hline Estilo de vida - life style & & & & & \\
\hline $\begin{array}{l}\text { Representações do Brasil } \\
\text { e símbolos nacionais }\end{array}$ & & & & & \\
\hline Cores & & & & & \\
\hline Matérias Primas Naturais & & & & & \\
\hline $\begin{array}{l}\text { Aplicações e Técnicas } \\
\text { artesanais }\end{array}$ & & & & & \\
\hline Tecidos & & & & & \\
\hline Estampa & & & & & \\
\hline Formas e volumes & & & & \\
\hline
\end{tabular}

\begin{tabular}{|l|l|l|l|l|l|}
\hline $\begin{array}{l}\text { Os seguintes atributos } \\
\text { representam fator de } \\
\text { diferenciação no produto } \\
\text { de moda }\end{array}$ & $\begin{array}{c}\text { c } \\
\text { Discordo } \\
\text { completamente }\end{array}$ & 2 & 3 & 4 & $\begin{array}{c}5 \\
\text { Concordo } \\
\text { completamente }\end{array}$ \\
\hline Estilo de vida - life style & & & & & \\
\hline $\begin{array}{l}\text { Representações do Brasil e } \\
\text { símbolos nacionais }\end{array}$ & & & & & \\
\hline Cores & & & & & \\
\hline Matérias Primas Naturais & & & & & \\
\hline $\begin{array}{l}\text { Aplicações e Técnicas } \\
\text { artesanais }\end{array}$ & & & & & \\
\hline Tecidos & & & & & \\
\hline Estampa & & & & \\
\hline Formas e volumes & & & & \\
\hline
\end{tabular}

Conhece outras formas de diferenciação de produto? Quais: 


\begin{tabular}{|c|c|c|c|c|c|}
\hline $\begin{array}{l}\text { As seguintes formas de } \\
\text { diferenciação são } \\
\text { fundamentais para o produto } \\
\text { de moda brasileiro no } \\
\text { mercado internacional? }\end{array}$ & $\begin{array}{c}1 \\
\text { Discordo } \\
\text { completamente }\end{array}$ & 2 & 3 & 4 & $\begin{array}{c}\text { Concordo } \\
\text { completamente }\end{array}$ \\
\hline $\begin{array}{c}\text { Diferenciação por imagem da } \\
\text { marca }\end{array}$ & & & & & \\
\hline $\begin{array}{c}\text { Diferenciação por suporte ou } \\
\text { serviços }\end{array}$ & & & & & \\
\hline Diferenciação por design & & & & & \\
\hline Diferenciação por qualidade & & & & & \\
\hline $\begin{array}{c}\text { Diferenciação por } \\
\text { Sustentabilidade }\end{array}$ & & & & & \\
\hline $\begin{array}{c}\text { Diferenciação por Inovação } \\
\text { Diferenciação pela imagem do } \\
\text { país de origem }\end{array}$ & & & & & \\
\hline
\end{tabular}

No seu entendimento, qual é a forma de diferenciação mais importante para comercialização de moda Brasileira no mercado internacional? 


\section{APÊNDICE 2 - ROTEIRO DE ENTREVISTA COM AGENTES DEMANDANTES}

Programa de Pós-Graduação em Administração

A imagem do país de origem como fonte de vantagem competitiva: um estudo exploratório no segmento da moda Brasileira

Roteiro 2: agentes demandantes

Data:____/2012 Local:

\section{Caracterização da empresa compradora:}

Company's Name:

Owners'names:

Company's age: Country of Origin:

Office's location:

How long have you been working in the fashion field?

Tell me a bit about your journey in this segment:

When did your company start buying from other countries?

How many retailers does your company supply?

Where are they from?

Have you got any idea of how many pieces your company per year?

\section{Atratividade por compra de produtos da Moda Brasileira:}

- How long has your company been buying fashion products from Brazil? (Há quanto tempo compra produtos de moda Brasileiro?)

- Do you know when your company started buying Brazilian apparel products more frequently? Why? (Quando passou a comprar mais produtos de moda Brasileiro? Por quê?)

- Which markets does your company distribute Brazilian apparel to? (Mercados em que distribui o produto brasileiro):

- Which markets appreciate Brazilian apparel? Why? (Mercados que valorizam o produto brasileiro? Por quê?)

- How many pieces of apparel from Brazil do you usually sell per year? (Quantidade de peças 
brasileiras comercializadas em média por ano)

- How many times have you come to Brazil through TexBrasil Project? (Quantas vezes já veio ao Brasil pelo Projeto TexBrasil?)

- Do you always come on business? How many pieces of Brazilian apparel you usually buy each time you negotiate with Brazilian brands? (Costuma comprar quantas peças a cada vez que negocia com marcas brasileiras?)

- Have you got an idea of how many Brazilian collections you've bought since you started trading with Brazil? (No de coleções brasileiras que comprou)

- What are the main brands/designers you buy from? Why? (Costuma comprar de quais marcas?)

\section{Diferenciacão de produto de moda:}

- When you buy products to resell, what are the attributes you consider? (Quando você compra moda para revender, quais atributos considera?)

- From your point of view, which characteristics does differentiated apparel present? (Para você, um produto de moda diferenciado é um produto que tem quais características? que tenha quais atributos?) $\mathrm{OU}$

\section{Compreensão sobre os atributos que compõem o conceito de Brasilidade na Moda:}

- In your opinion, what is Brazilian fashion like? (Para você, o que é a moda brasileira?)

- Do you believe that Brazilian fashion has an identity? What is it? (Você acredita que a moda brasileira tem uma identidade? Qual a identidade da moda brasileira?)

- When you think about Brazilian fashion, what comes to you mind? (Quando você pensa em moda brasileira, o que vem à sua mente?)

- Considering your experience in the fashion industry, what are Brazilian fashion characteristics? (A partir do que viu nos show rooms de marcas brasileiras que visitou e do seu conhecimento no segmento do moda, o que você entende por Brasilidade na moda?) 
- Could you tell me some of the attributes that you believe makes up brazilianess in fashion?(Quais são os atributos que compõem a brasilidade na moda? / Poderia me falar alguns atributos que você acredita que façam parte da Brasilidade na Moda?)

\section{$\underline{\text { Atributos da Brasilidade na Moda como fonte de vantagem competitiva }}$}

- What do you and your target value from Brazilian Fashion? (O que você e seu público valorizam na moda brasileira?)

- What are the main successful brands in terms of sales? Why? (Quais marcas fazem mais sucesso de vendas? Por quais motivos?)

Please indicate through a note, the degree of agreement or disagreement with the following statements regarding (being 1 strongly disagree and 5 completely agree):

\begin{tabular}{|l|l|l|l|l|l|}
\hline $\begin{array}{l}\text { The following elements } \\
\text { are characteristic of the } \\
\text { Brazilianness in fashion }\end{array}$ & Strongly disagree & 2 & 3 & 4 & $\begin{array}{c}5 \\
\text { Completely agree }\end{array}$ \\
\hline Brazilian lifestyle & & & & & \\
\hline $\begin{array}{l}\text { Representations of Brazil } \\
\text { and national symbols }\end{array}$ & & & & & \\
\hline Colors & & & & & \\
\hline Natural Raw Materials & & & & & \\
\hline $\begin{array}{l}\text { Applications and Craft } \\
\text { Techniques }\end{array}$ & & & & & \\
\hline Fabrics & & & & & \\
\hline Print/patterns & & & & & \\
\hline Shapes and volumes & & & & & \\
\hline
\end{tabular}

\begin{tabular}{|l|l|l|l|l|l|}
\hline $\begin{array}{l}\text { The following elements } \\
\text { of the Brazilianness in } \\
\text { fashion are valued by } \\
\text { the international } \\
\text { consumer market }\end{array}$ & $\begin{array}{c}1 \\
\text { Strongly disagree }\end{array}$ & 2 & 3 & 4 & $\begin{array}{c}5 \\
\text { Completely agree }\end{array}$ \\
\hline Brazilian lifestyle & & & & & \\
\hline $\begin{array}{l}\text { Representations of Brazil } \\
\text { and national symbols }\end{array}$ & & & & & \\
\hline Colors & & & & & \\
\hline Natural Raw Materials & & & & \\
\hline $\begin{array}{l}\text { Applications and Craft } \\
\text { Techniques }\end{array}$ & & & & & \\
\hline Fabrics & & & & & \\
\hline Print/patterns & & & & & \\
\hline Shapes and volumes & & & & & \\
\hline
\end{tabular}




\begin{tabular}{|l|l|l|l|l|l|}
\hline $\begin{array}{l}\text { The following attributes } \\
\text { represent factors of } \\
\text { differentiation in fashion } \\
\text { product }\end{array}$ & $\begin{array}{c}1 \\
\text { Strongly disagree }\end{array}$ & 2 & 3 & 4 & $\begin{array}{c}5 \\
\text { Completely agree }\end{array}$ \\
\hline Brazilian lifestyle & & & & & \\
\hline $\begin{array}{l}\text { Representations of Brazil } \\
\text { and national symbols }\end{array}$ & & & & & \\
\hline Colors & & & & & \\
\hline Natural Raw Materials & & & & & \\
\hline $\begin{array}{l}\text { Applications and Craft } \\
\text { Techniques }\end{array}$ & & & & & \\
\hline Fabrics & & & & & \\
\hline Print/patterns & & & & & \\
\hline Shapes and volumes & & & & & \\
\hline
\end{tabular}

Do you know other forms of product differentiation? What are they:

\begin{tabular}{|c|c|c|c|c|c|}
\hline $\begin{array}{l}\text { The following forms of } \\
\text { differentiation are } \\
\text { fundamental to Brazilian } \\
\text { fashion product in the } \\
\text { international market? }\end{array}$ & $\begin{array}{c}1 \\
\text { Strongly disagree }\end{array}$ & 2 & 3 & 4 & Completely agree \\
\hline Brand image differentiation & & & & & \\
\hline $\begin{array}{c}\text { Service and support } \\
\text { differentiation }\end{array}$ & & & & & \\
\hline Design differentiation & & & & & \\
\hline Differentiation through quality & & & & & \\
\hline $\begin{array}{c}\text { Differentiation through } \\
\text { Sustainability }\end{array}$ & & & & & \\
\hline $\begin{array}{c}\text { Inovation differentiation } \\
\text { Differentiation through country } \\
\text { of origin image }\end{array}$ & & & & & \\
\hline
\end{tabular}

In your opinion, what is the main form of differentiation to trade Brazilian fashion products in international markets? 